\author{
UNIVERSIDADE DE SÁO PAULO \\ FACULDADE DE CIENCIAS FARMACEUTICAS \\ Curso de Pós-Graduação em Fármaco e Medicamentos \\ Ārea de Produção e Controle Farmacêuticos
}

\title{
CONTAMINAÇÃO MICROBIANA EM MEDICAMENTOS FITOTERÁPICOS SOB A FORMA SÓLIDA
}

DOMINIQUE CORINNE HERMINE FISCHER

Dissertação para obtenção do grau de MESTRE

Orientador:

Prof. DIa. TAKAKO SAITO

São Paulo

1992 
A Deus,

pela inspiração e concretização deste trabalho,

À Professora Doutora TAKAKO SAITO

pelos ensinamentos e orientagão, compartithando sua experiênoia e indicando sempre o caminho da evolução em diregão ao aprimoramento. 
À minha mãe ANDRÉE,

a quem devo toda orientação de vida, apoio

e incentivo ao crescimento infindo.

AO meu pai GEORGES,

pelo exemplo de perseverança e incentivo.

$\grave{A}$ KATY,

minha segunda mãe.

Ao ELÁVIO, meu marido,

pelo auxizio e compreensão.

À Professora Doutora MARIA KUBOTA AKISUE,

pelo incentivo ao ingresso no pós-Graduação. 
À Coordenadoria do Curso de Pós-Graduação em Fármaco e Medicamentos do Departamento de Farmácia da Faculdade de Ciên cias Farmacêuticas da USP, pela oportunidade na efetivação do curso e obtenção do tituro.

$\dot{A}$ Professora Assistente Mitsuko Taba Ohara, do Departa mento de Farmácia da Faculdade de Ciências Farmacêuticas da USP, pela orientaçóo e apoio.

A todos os professores e funcionários do setor de Biofarmacognosia do Departamento de Farmácia da Faculdade de Ciências Farmacêuticas da USP, pela compreensão, múltiplos au xilios e inestimável apoio.

À Sra. Horizde de oliveira Castaldi pelo auxilio e tra batho imprescindiveis à execução da parte experimental deste trabalho.

Ao Laboratório de Controle Farmacêutico (CONFAR) do De partamento de Farmácia da Faculdade de Ciências Farmacêuticas da USP pela cessão de meios de cultura e permissão para utili zação de instalaçóes e equipamentos necessários à execução da parte experimental deste trabalho.

À Sra. Yara Maria Lima Mardegan, Secretária do Departa mento de Farmácia da Faculdade de Ciências Farmacêuticas da USP, pelo empenho e trabalho datilográfico. 
À bibliotecária Moema Rodrigues dos Santos, pela norma lizaça das referêneias bibliográficas.

À CAPES, pelo auxilio financeiro como bolaista.

A todos que direta ou indiretamente colaboraram na exe cucão do presente trabalho. 
DOMINIQUE CORINNE HERMINE FISCHER

CONTAMINAÇÃO MICROBIANA EN MEDICAMENTOS FITOTERÄPICOS

SOB A FORMA SÓLIDA

CONISSÃO JULGADORA

DISSERTAÇÃO PARA OBTENÇÃO DO GRAU DE MESTRE

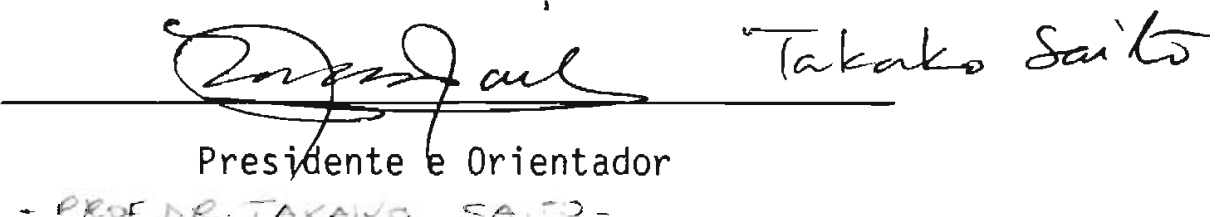

FLAVID ALEERTHUM

2 Examinador

- Poof.tit. Flávis ALTERTHM.

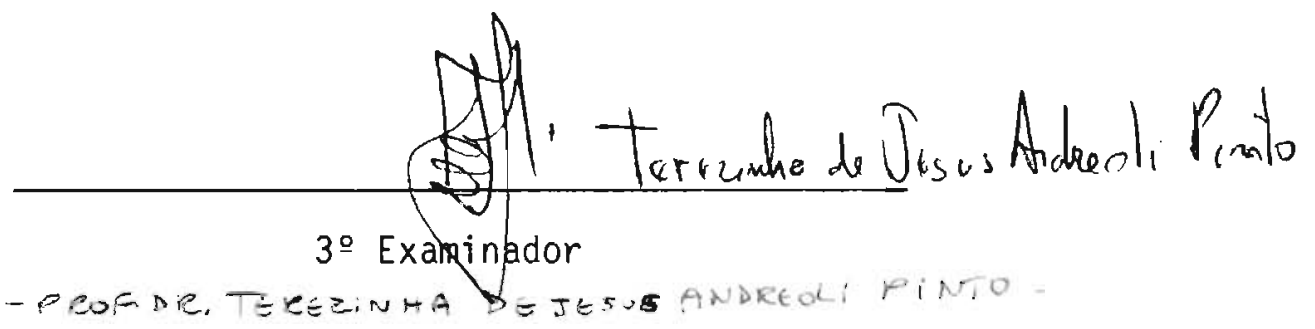

São Paulo, 02 de 04 de 1992. 


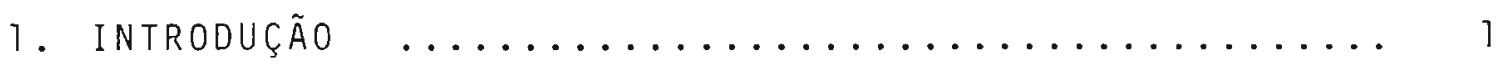

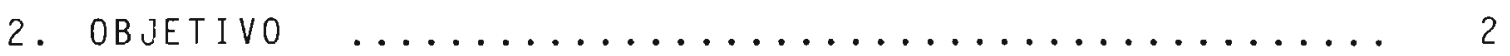

\section{REVISÃO BIBLIOGRĀFICA}

3.1 Aspectos clínicos da contaminação microbiana em medicamentos 3

3.2 Contaminação microbiana $\ldots \ldots \ldots \ldots \ldots \ldots \ldots \ldots . \ldots . \ldots . \ldots$

3.2.1 Contaminação microbiana em insumos farmacéuticos $\ldots . .99$

3.2.1.1 Contaminação microbiana em drogas vegetais ...... 11

3.2.2 Contaminação microbiana em medicamentos não estéreis .. 15

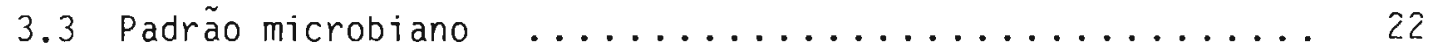

3.3.1 Padrão microbiano de insumos farmacéuticos ........ 22

3.3.2 Padrão microbiano de medicamentos não estéreis . . . . 27

3.4 Metodologia de avaliação $\ldots \ldots \ldots \ldots \ldots \ldots \ldots \ldots \ldots$

4. MATERIAL E MÉTODOS

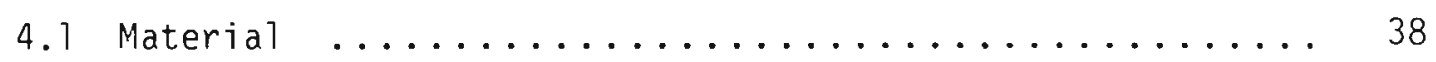

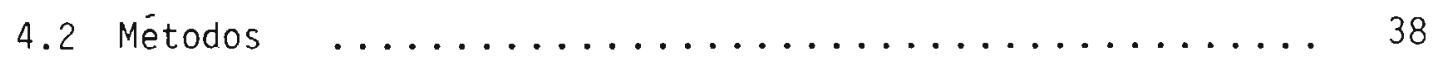

4.2.1 Apresentação comercial das amostras ........... 38

4.2 .1 .1 Droga vegetal .................... 38

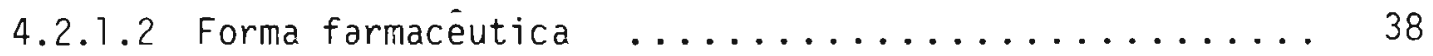

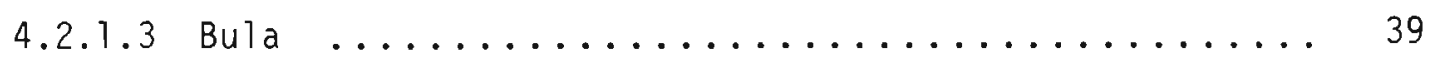

4.2.1.4 Identificação do ciclo produtivo $\ldots \ldots \ldots \ldots \ldots \ldots$

4.2.1.5 Embalagens primäria e secundäria ............. 39

4.2.1.6 Responsável técnico ................... 39

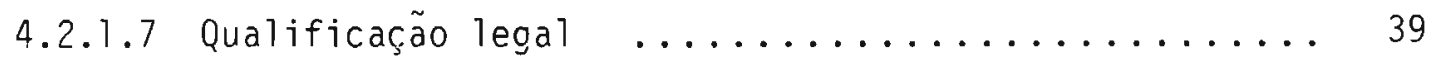

4.2 .1 .8 outras informações $\ldots \ldots \ldots \ldots \ldots \ldots \ldots \ldots \ldots \ldots . \ldots \ldots$

4.2.2 Tratamento e tomada de ensaio das amostras ......... 40

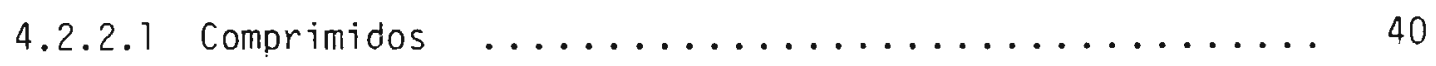

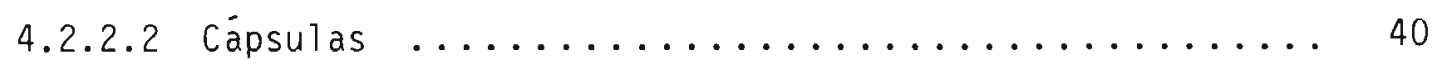

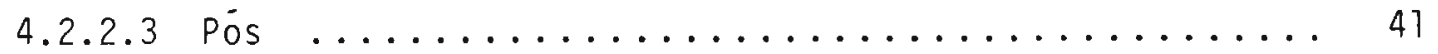

4.2.3 Determinação de contaminantes viáveis totais ....... 41

4.2.3.1 Determinação de bactérias aeróbias mesófilas viāveis totais .......................... 41 
4.2 .3 .1 .1 Técnica de tubo mültiplo ............... 41

4.2 .3 .1 .2 Técnica de àgar fundido ............... 42

4.2.3.2 Determinação de leveduras e bolores viàveis totais .... 42

4.2 .3 .2 .1 Técnica de tubo múttiplo ............... 42

4.2 .3 .2 .2 Técnica de àgar fundido ................ 43

4.2.3.3 Determinação de esporos de bactérias aeróbias mesó-

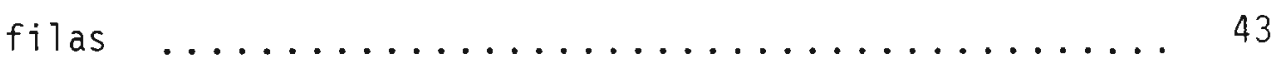

4.2 .4 Pesquisa de coliformes ................... 44

4.2.4.1 Prova presuntiva para coliformes totais .......... 44

4.2.4.2 Prova confirmatória para coliformes totais ........ 44

4.2.4.3 Prova confirmatória para coliformes fecais ......... 44

4.2.4.4 Prova confirmatória para Escherichia coli ......... 45

4.2 .4 .4 .1 Isolamento seletivo .................. 45

4.2.4.4.2 Identificação micromorfolögica .............. 45

4.2.4.4.3 Confirmação da fermentação de lactose ......... 45

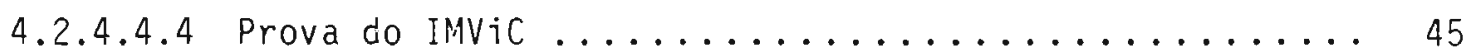

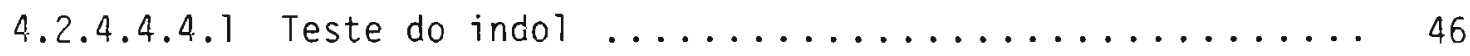

4.2 .4 .4 .4 .2 Teste de vermelho de metila $\ldots \ldots \ldots \ldots \ldots \ldots . \ldots 46$

4.2.4.4.4.3 Prova de Voges-Proskauer .............. 46

4.2.4.4.4.4 Prova de utilização do citrato $\ldots \ldots \ldots \ldots \ldots \ldots$

4.2 .5 Pesquisa de Salmonella sp. ............... 47

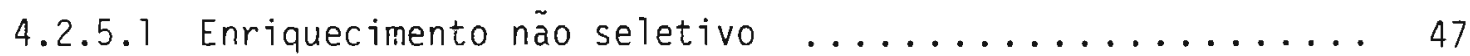

4.2 .5 .2 Enriquecimento seletivo ................ 47

4.2 .5 .3 Isolamento e identificação ............... 47

4.2 .6 Estimativa de Escherichia coli $\ldots \ldots \ldots \ldots \ldots \ldots$

5. RESULTADOS

5.1 Apresentação comercial das amostras ............. 49

5.2 Determinação de contaminantes viäveis totais. ........... 49

5.3 Pesquisa de patogénicos especificos .............. 49

5.3 .1 Pesquisa de coliformes e de Salmonella sp. .......... 49

5.3 .2 Isolamento e determinação de Escherichia coli $\ldots . . \ldots 50$ 
6. DISCUSSÃO

6.1 Considerações gerais $\ldots \ldots \ldots \ldots \ldots \ldots \ldots \ldots \ldots \ldots$

6.2 Apresentação comercial das amostras ........... 72

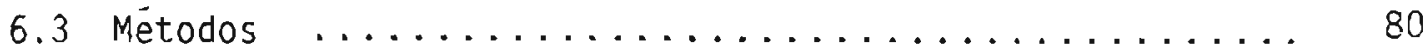

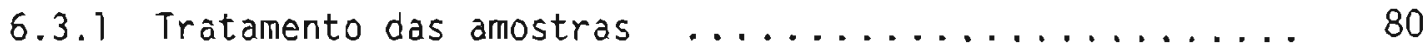

6.3 .2 Detecção de contaminantes viáveis $\ldots \ldots \ldots \ldots \ldots . \ldots . \ldots$

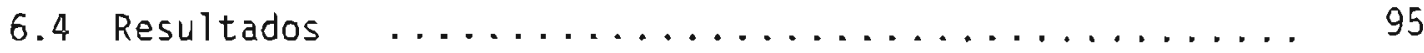

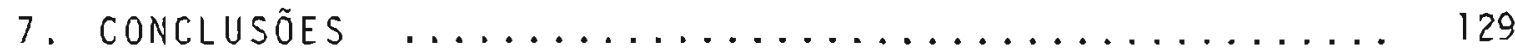

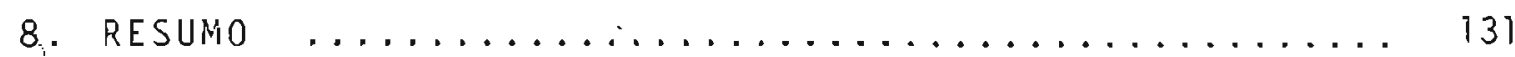

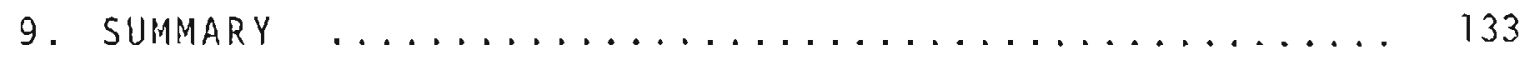

10. REFERÊNCIAS BIBLIOGRÁFICAS $\ldots \ldots \ldots \ldots \ldots \ldots \ldots \ldots \ldots$ 
1. INTROOUÇÃO

Em vista do crescente interesse pela medicina a base de pro dutos terapéuticos de origem natural, principalmente de drogas vegetais, defronta-se com uma situação preocupante. De um lado, o consumidor leigo, pouco saberia distinguir a medicina folclórica da medicina cientifica; de outro lado, grande número de produtores e comerciantes oportunistas, atë certo ponto, com respaldo legal pelo fato de a legislação pertinente ser insipiente.

Os fituterápicos, pela slia origem, são potencialmente contą minados por agentes microbianos, quer sejam saprófitas ou patogénicos. Por isto, niveis de qualidade devem ser exigidos a fim de que est.es medicamen tos não sejam responsáveis pela contaminação microbiana, comprometendo a integridade do paciente. Ao mesmo tempo, não devem deteriorar o produto, com isto diminuindo a eficácia terapéutica e aumentando o risco ao consumidor. 


\section{OBJETIVO}

0 presente trabalho tem como objetivo analisar alguns aspectos da contaminação microbiana em fitoteräpicos mais amplamente comercializados pelas farmácias, drogarias, lojas de produtos naturais e supermercados da ci dade de são Paulo, a fim de verificar a qualidade quanto à conformidade com os padrões internacionais de pureza microbiana para medicamentos não estéreis de uso oral. 


\section{REVISÃO BIBLIOGRÁFICA}

3.1 Aspectos clínicos da contaminação microbiana em medicamentos

A veiculação de agentes infecciosos por medicamentos encontrase devidamente documentada em inúmeros relatos e pubiicações, cujos problemas clínicos foram classificados por Dony (62). Um, das toxiinfecções, en de corrência da ingestão de medicamentos contaminados, e outro, das superinfecções, quando pela administração medicamentosa töpica sobre a pele e mucosas.

Diferentes formas farmacêuticas foram comprovadamente responsa bilizadas pela infecção em pacientes $(23,36,130,145,164,169,176,179)$, sempre que foi possivel o isolamento e identificação de diferentes espécies microbianas. Descreveram-se casos de infecções oculares $(10,89,93,217)$, pós-operatórias $(10,15,89,104,121,154,155)$, do aparelho digestivo $(48,64,93,97,102,120,181)$, do trato urinário $(81,104,121,186)$, do sistena respiratório $(154,174)$, da pe le $(15,42,132)$, até mesmo de meningite $(22,67,157)$, com consequèncias graves e fatais.

Problemas dessa natureza foram tratados, com maior ènfase, nã década de 60. Em 1965, houve casos de salmonelose em crianças tratadas com um xarope contaminado $(20)$.

No inicio de 1988 , Kallings e colaboradores (93) relataram 200 casos de salmonelose, na Suécia, er consequência da administração de comprimidos de tireóide contaminados por mais de 30 milhões de bactérias por grama (179), além de conter Salmonella muenchen, Salmonella bareiliy e grande nümero de coliformes, inclusive Escherichia coli termodúrica, tendo sido o pó de tireóide, a fonte de infecção.

Anteriormente, no período de 1965 a 1967, ocorreram episódios de infecçäo por Salmonella cubana, nos Estados Unidos e Inglaterra (64). 
Lang e colaboradores (102) descreveram 21 casos, entre abri) de 1965 a julho de 1966, ocorridos no Mospital Geral de Massachussets, em Boston. As investigações mostraram que o surto de infecção foi em função da ingestão de cápsulas de vermelho carmim, empregado como agente marcador no diagnóstico de doenças digestivas. As cápsulas incriminadas apresentaram con tagens de $10^{5}$ Salmonella cubana por grama. Também se verificaram casos na Ca lifórnia, no periodo de junho a julho do mesmo ano (97).

Outras infecções intestinais foram relatadas em função do uso de medicamento contendo Pseudomonas aeruginosa, como no Hospital St. Bartholomew's, en Londres (181), com carga do microorganismo variando de 15 a $1,4 \times 10^{4} ; \mathrm{mL}$ de àguà menta.

No caso de infecções oculares, Pseudomonas sp. foi geralmente o microorganismo envolvido (169). Na Suécia, em 1964, 8 casos foran en decorrência do uso de ungüento de hidrocortisona contendo neomicina e anfomicina e que estava contaminado con Pseudononas aeruginosa em niveis superiores a até $2 \times 10^{3} / \mathrm{g}(93)$. A mesma bactéria foi encontrada em solução salina empregada para o umedecimento de cörnea, durante operações intraoculares, tendo infectado 15 de 25 pacientes submetidos a esse tipo de intervenção cirürgica, em 1964, sendo que 6 apresentaram perda de visão em um dos olhos 110 , 89).

No mesmo ano, um ungüento oftálmico, contendo Pseudomonas pyocyanea causou infecções oculares graves (66). Estudos anteriores de wyk e Granstone (217) demonstraram que diferentes tipos de ungüentos, para o mesmo fim, não estavam estéreis numa proporção de $85,5 \%$ (com relação às 83 amostras analisadas), sendo que 19 apresentaran carga igual ou superior a 50 microorganismos por grama.

Värios autores relataran casos de infecção urinäria en conse quència do emprego de solução desinfetante ou líquido para lavagern de bexiga contaminados. Mitchell e Hayward, em 1966 (121), descreverarn 7 casos pós- 
operatórios pelo uso de solução antissēptica, contendo Pseudomonas sp., na desinfecção do reservatório do líquido de irrigação da bexiga. Casos semelhantes ocorreram com o uso de água supostamente estéril no enxágue dos instrumentos cirúrgicos e na lavagem da bexiga (104).

Em 1970, Toi encontrada Pseudononas muliivorans (EO-1) en $n \dot{i}-$ veis variando de $10^{3}$ a $3,3 \times 10^{3} / \mathrm{mL}$ em solução antisséptica empregada na conservação e limpeza de sondas urinärias, tendo causado infecção em 12 pacientes, sendo a maioria assintomática (81).

No caso de infecções respiratórias foram geralmente incriminados os equipamentios médicos $(145,154,169)$. Philitips, em 1966, relatou 4 casos de infecções pulmonares por Pseudomonas aeruginosa contaminante de gel de lidocaina empregado na lubrificação de sondas endotraqueais. Porém, a àgua e outros liquidos contaminados usados nos aparatos médicos também foran, reconhecidamente, fontes de infecção (154). Em: 1967, registraram surtos de pneumonia devido à inalação de soluções contidas em frascos de aerossóis,con taminadas por Klebsiella sp. (154). Episódio parecido foi descrito por Sanders e colaboradores (174), em 1970, em consequēncia da inalação de solução contaminada por Serratia marcescens.

Com relação a casos de meningite, em 1945, Evans (67) descre veu tal ocorréncia en 2 pacientes, con consequëncias fatais, após terem rece bido anestesia intratecal de solução de nupercaina, tendo sido uma das fontes incriminadas de Pseudomonas pyocyanea. No mesmo ano, Botterell e liagner (22) fizeram relato sobre outros 2 pacientes que desenvolveram a mesila doença, em função de injeção intratecal de penicilina contendo a mesma bactéria. Posteriormente, em 1966,2 recém-nascidos apresentaram meningite, tendo sofrido danos cerebrais permanentes, en decorréncia do emprego de solução sali na contaminada por Flavobacterium meningosepticum, na lavagem dos olhos (157).

Foram relatados surtos de infecção de feridas e infecções secundārias de lesões cutāneas pré-existentes, por värios tipos de pseudomonas 
presentes em cremes, loções e soluções desinfetantes $(145,169)$. Basset e colaboradores (15), em 1970, verificaram 9 casos de infecção de feridas cirúrgicas por Pseudomonas multivorans, tendo-se incriminado a solução antissépti ca de Savlon (uma mistura de clorhexidina e cetrimida) utilizada para limpe za da ärea a ser operada, nas cirurgias menores e no tratamento pós-operatório naquelas mais extensas. Noble e Savin (132) isolaram Pseudomonas aeruginosa de creme esteroidal, tendo sido responsável pela infecção de lesões cutàneas.

Na Nova Zeländia, em 1958, estudosde France (74) demonstraran a capacidade de sobrevida de Candida albicans em cremes para as mãos, mesmo concendo hexaclorofeno, tendo sido recuperada em grande número a partir desses produtos, usados num hospital-maternidade e representando un sério risco para os recém-nascidos.

Eril trabalho semelhante de 1959, Ayliffe e colaboradores (11), na Inglaterra, constataram a presença de bacilos Gram-negativos como Kleb siella sp., Pseudomonas aeruginosa e Escherichia coli em cremes para mãos a loçōes contendo o mesnio antibacteriano. Em loções de uri hospital inglés, os mesmos autores encontraram contagens de klebsiella aerogenes de até $2,3 \times 10^{4} / \mathrm{mL}$, apesar de conterem, também, o antisséptico. Esse tipo de con taminação representa uma fonte potencial de infecçāo de dificil suspeita, co mo ocorreu com o surto de septiceria em 6 pacientes com sondas intravenosas, como consequência de cremes para as mãos empregados pelos médicos e contaminados por Klebsiella pneumoniae (124).

Em 1970, em Lonáres, houve casos de infecção intestinal em recérn-nascidos, nos quais foram aplicadas soluções antissépticas para a limpeza da pele, as quais foram posteriormente confirmadas como contaminadas (48).

Outros surios ocorreram em função do emprego de soluções desin fetantes contaminadas por Pseudomonas sp., de 1966 a $1971(42,81,121,155,186)$. 
A administração de vacinas e soros contaminados provocou mortes $(169,176)$. Isto ocorreu com injeção de soro anti-sarampo (intramuscular em 2 crianças) e de tuberculina (subcutãnea, em 1 criança), tendo levado a óbito 3 crianças. A análise das amostras dos materiais injetados evidenciou a presença de Staphylococcus aureus coln alto potencial toxigénico (141). Fato parecido deu-se, anteriormente, em 1928, na Ausirälia, en Bundaberg, após a aplicação subcutänea de vacina antidiftérica, tendo levado à morte 12 de 21 crianças imunizadas $(72,141)$. Outros inunoterápicos contaminados como vacina meningocócica (169), vacina contra a peste e linfa usada para a inuniza ção (176) trouxeram problemas.

Os injetáveis intravenosos foram responsäveis for 350 casos de septicemias, em hospitais dos Estados Unidos, em 1971 , tendo sido isoladas Enterobacter cloacae e Erwinia sp. (209). Värias cepas de enterobactérias foram, tambëm, detectadas eni solução salina glicosada, tendo causado pequeno surto infeccioso, após a administração intravenosa, ná Inglaterra, en: 1965 (145).

Alguns casos clínicos ocorrerami en função de contariinação por anaeröbios. Em 1949, Sevitt (180) descreveu 2 casos de tétano pós-cirürgico, em consequência do uso de talco contaninado por cepas de clostridium sp., in cluindo clostridium tetani toxigênica pela equipe médica antes da operação, para calçamento de luvas.

Anteriormente, em 1946, jä haviam sido registradas 4 mortes de bebès, também atribuidas ao uso de talco, na Nova Zelândia e Austrália (36).

Outros pós foram fonte de infecção, tendo sido constatada contaminação em pó de sulfonamida, por Welch e colaboradores (212), en 1942, que detectaran a presença de Staphylococcus sp., Streptococcus sp., bactérias aeróbias e anaeróbias esporuladas. Hais taróe, en 1965, Dony e Gérard (120) mencionaram a contaminação de pancreacina por Salmonella sp.como fonte de problemas clínicos em um hospital. 
0 isolamento de Staphylococcus epidermidis em medicamentos foi considerado significativo. Este microoorganismo causou infecções, o que alte rou a sua classificação, passando de sapröfita a patógeno oportunista $(5,85)$. Suã presença foi confirmada em medicamentos sob a forma sölida (93) e líquida (56).

Outros patógenos oportunistas foram citados por Hitokoto e colaboradores (85), em 1978, incluindo Aspergillus niger e Candida albicans. 


\subsection{Contaminação microbiana}

3.2.1 Contaminação microbiana em insumos farmacéuticos

No tocante aos insumos farmacẽuticos, muitos autores averiguaram sua qualidade microbiolögica $(12,20,21,38,72,73,83,93,99,100,109,111,147$, $151,176,185,190,213,216)$.

As matérias-primas de origem sintëtica ou substancias isoladas no estado puro apresentaram grau minimo de contaminação $(151,151)$, porém ten do sido consideradas exceção as substanncias orgänicas como vitaminas, lactose, esteróides entre outras além das minerais, comc talco a fosfatos $(72,151$, 185). Até mesmo algumas substãncias sintëticas apresentaram contaminação maciça, como sulfamida e corantes (83). Porém, de forma geral, as matérias-pri mas naturais se mostraram mais contaminacias $(12,20,83,99,111,151,185,190)$ sen do os microorganismos encontrados reflexos da sua origem $(12,62,110,161,187)$.

Henning (84), em 1970, classificou os insumos farmacéuticos en 3 categorias, segundo o grau de contaminação: aqueles contenco, geralmente, elevado conteúdo microbiano devido à contaminação pririária ou secundária, ou tros apresentando grau mediano eli função da contaminação secundária e o terceiro grupo de nivel moderado em que a maior parte é atribuída à contamina ção secundäria. Pertencian a essas categorias, respectivamente, matérias-prí mas de origem animal (exiratos e órgãos pulverizados), vegetal (goma arábica e adraganta, ariido, ágar, cacau e outros) e mineral.

En 1965, em levantanento feito pelo Conselho Nacional de Saúde da Suécia (168), amostras de diferentes tipos de amido apresentaran contagens de até $2 \times 10^{4} / \mathrm{g}$, tendo sido detectada a presença de coliformes en 38 das 50 analisadas.

O estudo efetuado pela Food aná Drug Administrâtion (FDA) (109), en 1967, confirmou a detecção de salmonelas eri pó de tireóide, proveniente 
da Dinamarca, o que motivou a verificação da qualidade microbiológica de todas as iriportações americanas de insumos de origem animal. 0 mesmo orgão verificou a presença de vários sorotipos de Salmonella em insumos equivalentes, produzidos no próprio pais, além dos produtos derivados desses, o que levou ao recolhiniento desses últimos por parte das indústrias. A FDA constatou, ainda, a contaminação de levedura seca pela mesma bactéria.

Elevada carga microbiana foi encontrada em lactato de cálcio, carvão medicinal, folha de digitalis e tireóide por Fischer e colaboradores (73), em 1968.

No mesmo ano, Pedersen e U1rich (147) analisaram 84 matériasprimas diferentes, tendo detectacio contagens bacterianas ácé mesmo superiores a $10^{4} / \mathrm{g}$ em àgar, amido, cacau, caulim, folha de digitalis, alcaçuz. Uma amostra de digitalis superou o nivel de $10^{7} / \mathrm{g}$. Escherichia coli foi encontra da em niveis variando de 30 a $10^{2}$ por grama em 9 lotes, correspondentes a 7 matérias-primas diferentes, entre elas: amido de batata, folha de digitalis, lactose, prednisolona, prednisona e talco. E, ainda, 1 lote de alcaçuz acusou Escherichia coli no nivel de $10^{4} / \mathrm{g}$.

Bühlmann e colaboradores (38) avaliaram a pureza microbiológica de adjuvantes farmacotécnicos de 4 indústrias farmacéuticas suecas, no pe riodo de 1970 a 1971 , tendo observado, na maioria das vezes, cargas bacterianas e füngicas inferiores, respectivamente a $10^{3}$ e $10^{2} / \mathrm{g}(\mathrm{mL})$. Dentre 71 matérias-primas os autores encontraram microorganismos indesejáveis em arridos de trigo, milho e batata, àgar, alginato de sódio, cacau, celulose microcristalina, cacau em pó, gelatina, noz moscada pulverizada e talco.

Em 1972, Wózniak e colaboradores (216) constataram niveis de até $10^{7}$ microorganismos por grama em opoterápicos, tendo verificado as maiores cargas em tireóide, fator intrínseco e extrato ósseo, além de que, todos apresentaram fungos. 
Em pesquisa realizada por Kruger (99), em 1973, com 114 matérias-primas correspondendo a 1032 lotes, foram verificados niveis de contami nação superiores a $10^{3}$ bactérias e $10^{2}$ fungos por grama, respectivamente em 12,2 e $14,9 \%$.

Widmann e Croome (215), em 1975, isolaram enterobactérias de insumos como gelatina, goma arábica, cacau, amidos de arroz e de milho entre outros, sendo que Enterobacter cloacae foi o contaminante mais comum.

Na Índia, em 1976, Ferreira e Freitas (72) verificaram a condi ção microbiológica de talco 200 e 300, caulim, óxido de zinco e carbonato de magnésio, utilizados na formulação de talcos. Encontraram Staphylococcus aureus em 1 dos 8 pós anaỉisados. Â contagem de microorganismos viáveis fúi in ferior a $10^{2} / \mathrm{g}$ em $50 \%$ das amostras, sendo a maioria de bactérias aeróbias Gram-positivas esporuladas. Caulim e talco foram os mais contaminados, porém não acusaram a presença de patogènicos.

No mesmo país, em 1985, El Sovod (65) identificou até 65 tipos de contaminantes füngicos em 18 pós de uso farmacéutico, inclusive, espécies potencialmente patogènicas.

\subsubsection{Contaminação microbiana em drogas vegetais}

Considerado insumo farmacéutico, as drogas vegetais quer para o isolamento de seus principios ativos, quer sob a forma de infuso ou "in na tura" tiveram seu consumo aumentado, sobretudo nos ültimos anos em todo mundo (148). A Organização Mundial da Saúde (1) adotou programa de saúde básica (primäria) fazendo uso das plantas medicinais, a partir da década de 70. Assim, procurou incentivar os países membros a identificar e explorar os aspectos da medicina tradicional, a fim de obter medicamentos eficazes.

Numerosos pesquisadores de diversos países dedicaram-se ao estudo das drogas vegetais, muitos deles, especificamente no que se relaciona 
à qualidade microbiológica das mesmas $(9,17,20,49,55,59,62,75,82,86,95,110$, $114,131,171,177,213)$.

Em função da origem natural, as drogas vegetais geralmente apresentam altas contagens microbianas $(9,36,55,59,62,82,95,110,131,213)$, ten do alcançado niveis máximos de contaminação de $10^{8}$ bactérias (9) e $10^{7}$ fungos (95) por grama. Os microorganismos contaminantes mais frequentes foram bacilos Gram-positivos esporulados (53,55,213), bacilos Gram-negativos (213), aeróbios-anaeróbios facultativos ou oxidativos (55). As espécies mais frequentemente isoladas foram de enterobactérias $(20,49,55,59,62,131,177)$, clos trídios sulfito-redutores como Clostridium perfringens $(9,49,110,131)$, bem como, Staphylococcus aureus (131), Staphylococcus epidermidis (110), Pseudomonas sp., Pseudomonas aeruginosa $(49,131)$ e estreptococos fecais $(49,55,62$, 110). Entre as enterobactérias foram encontradas, comumente, coliformes (59, 177), Escherichia coli $(9,20,49,55,130)$, Proteus sp. (130), Proteus vulgaris (49), Enterobacter sp. (130), Enterobacter agglomerans (55), Enterobacter ae $\underline{\text { rogenes }}(55)$, Enterobacter cloacae $(49,110)$, Citrobacter sp. $(49,110,130)$, Klebsiella sp. (130), Klebsiella pneumoniae $(49,55,110)$ e Serratia sp. (130). Além dessas, bactérias da flora vegetal normal como Pseudomonas putida, Erwinia sp. (49) e Erwinia agglomerans (110) foram isoladas.

Entre os fungos, destacou-se a presença de bolores (213), tendo sido gēneros mais comuns Mucor $(62,114)$, Aspergillus $(62,86,114)$, PenicilIum $(62,86,114)$, Rhizopus (114) e Thamnidium (114).

Considerando que o vegetal pode ser analisado como um todo ou isoladamente através de partes integrantes, o resultado analítico pode acu sar divergéncias entre pesquisadores. Cortez e colaboradores (49), em 1986, não consideraram significativas as diferenças de contaminação microbiológica entre os órgãos do vegetal (folha, caule, raiz e flor). Entretanto, Negretti (131), em 1983, havia verificado maior nivel de contaminação por microorganismos indesejáveis ou patogénicos, em ordem decrescente de importáncia em raiz-rizoma, casca e folha, enquanto que o vegetal inteiro e o fruto 
apresentaram baixa contaminação.

Os resultados de Kedzia e Holderna (95), em 1984, assemelham se aos anteriores (131), com algumas diferenças. As porções vegetais que apresentaram menor nivel de contaminação microbiana foram fruto, semente e casca, ao contrário de folina, flor e rizoma, sendo que o maior nível foi en. contrado em raiz.

Na verificação da pureza microbiana de drogas vegetais brutas e de produtos extrativos (extratos fluido, seco, tinturas e essencias), Negretti (131) comprovou cargas microbianas altas nas drogas brutas, sendo que, $50 \%$ das 350 amostras analisadas apresentaram contagem bacteriana superior a $10^{3} / \mathrm{g}$, diferentemente das 200 amostras constituidas de seus derivaáos, cuja carga contaminante foi menor. A presença de microorganismos patogénicos, semelhantemente foi maior nas drogas brutas $(23,14 \%)$ do que nos produtos extra tivos $(9,0 \%)$. Da mesma forma, a presença de bactérias foi maior nas drogas $(11,71 \%$ das 350 amostras), seguidos de extrato $\operatorname{seco}(8,33 \%$ dos 60 analisados $)$, extrato fluido $(3,39 \%$ dos 60 analisados) e essencias $(5,0 \%$ das 40 analisa das).

Härtling (82), em 1983, analisou 20 amostras de chás correspon dendo a 14 misturas de drogas, alérn de folhas e frutos de sene comercializadas na Alemanha. As contagens bacteriana e füngica variaram, respectivamente, de 25 a $1,2 \times 10^{6}$ e de 0 a $2,6 \times 10^{3}$ por grama, tendo isolado enterobactérias de 11 das amostras, sendo que 7 destas apresentaram carga superior ou igual a $100 / 9$.

Alguns autores demonstraram especial preocupação com relação aos contaminantes fúngicos, con vistas à averiguação da presença ou não de aflatoxinas $(86,114,171)$.

Hitoko e colaboradores (86) avaliaram 49 amostras totalizando 13 espécies vegetais, entre elas canela, gengibre, alcaçuz e plantas nativas do Japão. 
As espécies fúngicas mais frequentes foram Aspergillus e penicillum, porém, não foram detectadas micotoxinas.

Lutomsky e Kedzia (114) constataram que, $60 \%$ das 246 amostras de drogas brutas, por eles analisadas, apresentaran contagem de contaminan tes füngicos variando de $10^{2}$ a $10^{4} / \mathrm{g}$ e $30 \%$ com nivel superior a $10^{4} / \mathrm{g}$. As cepas toxigenicas foram raras, sendo que apenas 2 produziram aflatoxina $B_{1}$.

Na Índia, onde grande parte da população faz uso das plantas para tratamento de doenças, Roy e Chourasia (171), em 1989, fizeram levantamento da micoflora presente em 5 drogas vegetais nativas, sendo elas: Cyperus rotundus (tübera), Gmelina arborea (raiz), Hygrophila spinosa (semente), Mesua ferrea (semente) e Solanum nigrum (baga). Estas são usadas comumente por suas ações diurētica, estomāquica, adstringente, carminativa, afrodisiaca e diaforética. Os autores verificaram a presença comum de espécies perten centes aos gēneros Alternaria, Aspergillus, Curvularia, Fusarium, Penicillum, Rhizopus, Botrytis e Chaetomium. Porém, Aspergillus flavus foi predominante, na maioria das amostras, sendo que das 50 cepas isoladas 21 foram toxigêni cas. 0 nivel de aflatoxina $B_{1}$ na major parte das amostras contaminadas ultra passou o limite de toleráncia de $20 \mathrm{ug} / \mathrm{kg}$, fixado pela OMS. O maior nivel de contaminação por aflatoxina foi registrado em Hygrophila spinosa e o menor, em Gmelina arborea, tendo sido, respectivamente, de $1,11 \times 10^{3}$ e $1,4 \times 10^{2}$ $\mu \mathrm{g} / \mathrm{kg}$. Mesua ferrea não apresentou tal tipo de contaminação.

As drogas vegetais quando fragmentadas ou puiverizadas apresen tam., geralmente, nivel de contaminação superior àquelas inteiras. Este fato foi observado por Schiller e colaboradores (177), em 1968, em folhas de jaborandi e por Westwood (213), em 1971, em goma adraganta e ruibarbo. Da mesma forma, em análise efetuada por Devleeschouwer e Dony (55), em 1979, em chä de folha de boldo, uva ursi, sälvia, eucalipto, malva e hortelé, os auto res encontraram, na maioria das vezes, contariinação bacteriana em nivel supe rior nas drogas divididas. Esta diferença, em alguns casos como na amostra 
de sálvia atingia 5 ciclos logarítmicos. Entretanto, no caso da contaminação fúngica, verificaram geralmente o conträrio. Observaram, ainda, variação qua litativa quanto aos contaminantes encontrados nos 2 casos. Constataram, também, diferença em função da consistencia das folhas, pois para casos de consistência dura o nīvel de contaminação bacteriana era inferior àqueles de fó Thas moles. 0 mesmo foi verificado quanto à contaminação füngica, embora em nivel inferior à contagem bacteriana.

Em outras constataçōes publicadas na década de 80 são relatados resulicados semelhantes da carga contaminante $(17,49,110)$. Em 50\% das 12 amostras de Mentha piperita a presença de bactérias aeróbias mesófilas era superior a $10^{6} / \mathrm{g}$, havendo sinais de contaminação fecâl humana ou añimâl er.? casos (110). Contaminação fúngica elevada, situada entre $10^{5}$ e $10^{7} / \mathrm{g}$, foi encontrada eri $10 \%$ dos 79 lotes de drogas vegetais analisadas por cortez e cola boradores (49). Com relação a contaminante bacteriano, esses autores detecta ram cargas superiores a $5 \times 10^{5} / \mathrm{g}$ em $25 \%$ das amostras.

\subsubsection{Contaminação microbiana em medicamentos não estéreis}

A qualidade microbiológica dos fitoterápicos, assin como de ou tros medicamentos não estéreis, depende de värios fatores. Entre eles, desta ca-se a qualidade das matérias-primas $(6,8,12,21,41,47,53,61,62,73,77,87,101$, $131,151,164,183,219)$ representada, principalmente, pelas drogas e excipientes de origem natural, originalmente contaminados $(8,72,20,35,59,82,73,151$, $162,177,191,213,219)$. O que está relacionado às condições de cultivo $(9,131)$, colheita $(62,131,150,151)$ e armazenamento $(12,62,98,101,131,151)$, além de que sua manipulação através de operações como a pulverização, tamisação, acondicionamento e embalagem (101) igualmente pode interferir.

O efeito do processo de fabricação sobre os microorganismos(21, $78,101,114,131,750,177)$ é aspecto imporianıe. Assim, no caso de comprimidos, 
- processo de granulação e secagem a $35-40^{\circ} \mathrm{C}$ favorece o desenvolvimento microbiano $(62,101)$. Se a temperatura for de $80^{\circ} \mathrm{C}$, os contaminantes mais resis tentes são selecionados (158), havendo redução do número de microorganismos inicialmente presentes (177). Na encapsulação, contrariamente, pode haver contaminação en função da manipulação.

Outros pontos devem ser considerados durante o processo de fabricação, como a qualidade do ar $(46,62,98)$, o local de produção $(8,12,41,46$, $51,62,77,151,162)$, os materiais e equipanentos $(12,23,41,62,101,108,151,162)$ e o acondicionamento (101).

0 pessoal é o veículo mais importante de contaminação na fabri cação $(12,41,46,62,77,98,108,151,162,219)$ interferindo desde a manipulação de matérias-primas (101) até o acondicionamento, desempenhando papel fundamental na dissemínação dos microorganismos através das mãos $(8,77,108,219)$ e da pele $(41,219)$, aiéni das vias respiratörias $(41,98,219)$ e digestiva (41), beri como dos cabelos $(98)$ e vestimentas $(41,46)$, havendo emissão de particulas $(46,62,98)$, que pode ser acentuada de acordo com a atividade em questão.

A composição da förmula pode favorecer ou não o desenvolvimento iiicrobiano durante a produção e o uso (62).

Após a fabricação, o armazenamento é determinante, sendo que condiçôes de alta temperatura e umidade são favoráveis ao desenvolvimento microbiano (27), assin como problemas decorrentes do acondicionamento (151, $162,183)$.

0 inicio dos estudos sobre a contaminação microbiana em medica mentos não estêreis deu-se em decorréncia dos problemas clînicos ocorridos, na década de 60, que foram atribuídos, comprovadamente, a medicamentos de má qualióade.

Kalings e colaboradores (93), en 1966, na Suécia, foram os primeiros a avaliar a qualidade microbiológica de värias formas farmacéuticas. Analisando 600 lotes de diferentes produtos, incluindo unguientos, cremes, 
linirmentos, pós e cremes infantis, isolaram värias espécies bacterianas e fúngicas, entre elas Staphylococcus aureus, Pseudomonas aeruginosa, Bacilius subtilis, Alcaligenes sp. e leveduras. Analisaram, tambén, 160 lotes de comprimidos, dos quais 63 , altamente contaminados, tendo apresentado bactérias como Bacillus subtilis, Staphylococcus albus, Alcaligenes sp. e bolores, e 38 amostras contendo coliformes em niveis da ordem de milhões por grama, além de outras espécies. En 32 lotes detectaranı coliformes termoresistentes, sendo que, em 15 deles os niveis superaram $10^{3} / \mathrm{g}$. Onze das 28 amostras de pós para uso infantil e para uso em feridas apresentaram cargas bacterianas superiores a $10^{3} / \mathrm{g}$.

Os estlidos de Kallings e colabcradores (93) chamaram a atenção para o problema da contaminação microbiana em medicamentos, tendo servido de ponto de partida e incentivo para trabalhos de outros pesquisadores, em todo o mundo $(5,6,23,40,53,54,62,73,101,138,139,140,164,184)$. Constatou-se que me dicamentos de uso oral estavam especialmente contaminados (164) em relação aos outros, e entre eles, os de forma sölida foram apontados, por alguns autores (53), como sendo os que continham maior carga microbiana, diferindo de outros pesquisadores $(40,54,62)$ que verificaram tal fato em outras formas farmacèuticas.

Na Inglaterra, em 1971, foi demonstrado que produtos farmacéuticos de uso oral e tópico industrializados, apresentavam melhor qualidade microbiolögica quando comparados àqueles preparados en farmácias hospitala res (164). Em contraste, Fischer e colaboradores (73) ben como FuglsangSmidt e Ulrich (184) haviam encontrado resuliados de pureza microbiana semeIhantes, tanto para comprimidos produzidos em farmácias quanto em indústrias da Dinarnarca, tendo obtido contagens bacterianas inferiores a $10^{3} / \mathrm{g}$ na maioria dos casos.

Sabe-se que a qualidade microbiológica do produto final é influenciada, diretamente, entre outros fatores, anteriormente comentados, 
pela qualidade das matërias-primas, em função de sua natureza e origem (21, $62,73,76,84,93,101,109,111,122,140,151,164)$.

Muitos pesquisadores comprovaram, de um modo geral, a presença de altas contagens microbianas nos medicamentos contendo insumos farmacéuticos eiou principios ativos de origem natural, tendo sido superiores àquelas encontradas nos produtos com apenas componentes de origem sintética $(53,62$, $73,101,139,140,164)$.

Desvignes e colaboradores (53) detectaram niveis de contaminação bacteriana maiores que $10^{4} / \mathrm{g}$ em $4,5,12,5$ e $2,0 \%$ dos medicamentos consti tuijos, respectivamente, por insumos de naturezas vegetal, animal e sintética.

Entre värias matérias-primas, o amido de batata foi o responsá vel pela contaminação em comprimidos, pois Kallings e colaboradores (93) encontraram coliformes em níveis da ordem de até $120 / g$ nos lotes apresentando carga bacteriana total de até $10^{4} / \mathrm{g}$. Da mesma forma, o pó de tireóide, empre gado na fabricação dos comprimidos correspondentes, foi o causador do surto de salmonelose ocorrido, na suécia, no inicio de 1966 (93). A análise do mes mo demonstrou a presença de 30 milhões de bactérias por grama, sendo a maio ria da flora fecal. Isolou-se, além disso, Salmonella muenchen e salmonella bareilly. Resultados semelhantes aos de Kallings e colaboradores foram verificados por Fischer e colaboradores $(73,184) 2$ anos mais tarde. Assim, 2 10tes de comprimidos de tireóide industrializados (184) apresentaram niveis bacterianos de até $10^{4}$ /comprimido, e 1 lote de comprimidos de tireóide e 1 de carvão medicinal, produzidos em farmàcias finamarquesas (73) tiveram carga bacteriana alcançando nivel de até $10^{5}$ /unidade. Os autores também puderam comprovar que comprimidos contendo drogas de origen natural, como carvão medicinal, folha de digitialis e tireóide foram os que acusaram as contagens mais elevadas. No único lote de comprimidos de digitalis padrão, as contagens variaram entre $10^{5}$ e $10^{6}$ bactérias por comprimido. 
Através de värios estudos foi constatado que hà predominäncia de certas espécies contaminantes em determinados tipos de produtos. Os medicamentos administrados por via oral podem conter vários tipos de microorga nismos, principaimente, Bacillus sp., cocos Gram-positivos e fungos, provocando sérias consequéncias do ponto de vista da saúde do consumidor bem como acarretando problemas de risco do produtor $(6,62)$.

Em amplo estudo realizado por Dony (62), em 1977, medicamentos sob a forma sólida como comprimidos, pós, drágeas e granulados apresentaram carga bacteriana inferior a $10^{2} / \mathrm{g}$, sendo geralmente de bacilos aeróbios espo rulados. Além disso, a presença de enterobactêrias, estreptococos fecais e fungos foi relacionada com a inclusão de insumos de origemin natural.

No caso dos medicamentos com base aquosa como soluções, suspen sões e cremes, verificou-se, mais comumente, a presença de enterobactérias e Pseudomonas sp. $(62,140)$, sendo que soluções constituidas de princípios ativos naturais apresentaram bactérias esporuladas (139); as suspensões contendo os mesmos tipos de componentes acusaram carga total superior a $10^{5} / \mathrm{mL}$.

Particularmente, com relação a formas farmacéuticas sólidas de uso oral, Lambin e colaboradores (101), em 1953, mesmo anteriormente à década de 60 , considerando os comprimidos como a forma farmacêutica mais emprega da na época, preocuparam-se com a possibilidade de veiculação de microorganismos através deles. Realizaram, assim, anālise microbiológica em comprimidos de värios tipos, contendo principios ativos variados, entre os quais iso lados de vegetais ou sintëticos (adrenalina, digitalina, sulfato de morfina, sulfato de estricnina), de origer animal (extrato de medula, pó de ovário, pó de fígado, pó de testiculo, pó de gländulas supra-renais, pó de tireóidel e fermentos lácticos. As contagens bacterianas variaram de 0 a $1,2 \times 10^{4}$ por comprimido naqueles contendo principios ativos naturais.

Outros autores fizeram levantamento da pureza microbiológica de formas farmacéuticas sólidas $(5,6,40,53,54,65,73,91,127,184)$. 
Considerando-se as exigéncias microbianas com relação do teor de água livre (atividade de água) (62) esperava-se que as formas sólidas não favorecessem o desenvolvimento microbiano. Porém, Desvignes e colaboradores (53), em 1973, verificaram que estavam entre as formas galēnicas mais contaminadas, tendo sido detectados niveis bacterianos até mesmo superiores a $10^{4} / g$ em comprimidos, drägeas, cápsulas e granulados, com frequência, respec tivamente, de $7,5,11,0,4,5$ e 7,0\%. A mesma pesquisa acusou a presença de clostridios sulfito-redutores em 2 das amostras de drágeas e, em 1 das 54 amostras de comprimidos, aléril de estafilococos patogénicos em 1 amostra de comprimido e estreptococos, em 2 das 28 de granulados.

Na Índia, Jain e Chauhan (9)!), em 1978, verificaram contagem total de $4,36 \times 10^{3} / \mathrm{g}$ em 10 lotes de comprimidos de anti-ácidos, fabricados por diferentes indústrias. Dois deles acusaram apenas contaminação por bactérias, enquanto que os demais apresentaram fungos. As espécies microbianas mais frequentes foram Escherichia coli, Staphylococcus aureus, Staphylococcus pyogenes, Pseudomonas aeruginosa, Bacillus mirabilis, Bacillus coagulans e xlebsiella pneumoniae. Entre os fungos destacaram-se espécies como Aspergillus niger, Mucor sp., Alternaria sp., cada uma delas presente em $30 \%$ dos produtos analisados.

Em 1979, Devleeschouwer e Dony (54) em análise microbiológica efetuada en 30 pilulas e 26 cápsulas constataram qualidade inferior àquela encontrada por Desvignes e colaboradores (53) pois $34,6 \%$ tiveram contagens bacterianas superiores a $10 \%$. No caso de pilulas, $40 \%$ apresentou carga de bactérias aeröbias viäveis inferior a $10^{4} / \mathrm{g}$. A contaminação füngica foi rela tivamente baixa. Todas as cápsulas e 17 amostras de pilulas tiveran contagem superior a $10^{2} / g$. Os bacilos esporulados Gram-positivos foram predominantes (93\% das amostras). Nove amostras de pilulas e 5 de cápsulas revelaram-se contaminadas por Staphylococcus sp. As pilulas acusaram, ainda, presença de bacilos Gram-negativos, espécies aeröbias e anaeröbias facultativas, entero- 
bactérias, espécies aeróbias estritas, Xanthomonas sp., Acinetobacter sp., estreptococos, bacilos Gram-negativos aeröbios estritos.

Contrariamente, os dados revelados por estudos anteriores de Buogo e Ratti (40), em 1972, indicaram niveis baixos de contaminação em cápsulas gelatinosas, comprimidos e drágeas, não tendo sido isolada Escherichia coli.

Em 1983, na Espanha, Arribas e colaboradores (5) avaliaram um total de 237 amostras constituídas de 4 formas farmacẽuticas sólidas de uso oral tendo isolado 48 cepas de cocos Gram-positivos cuja maior percentagem foi encontrada eni comprimidos $(52,08 \%)$, seguidos de drágeas $(22,92 \%)$, pós $(15,66 \%)$ e cápsulas $(8,33 \%)$.

Os gëneros mais frequentes foram Staphylococcus, Micrococcus e Streptococcus. Este ültimo foi encontrado apenas em comprimidos e cápsulas, mas a maior proporção desses microorganismos foi observada em comprimidos. Não isolaram Staphylococcus aureus, porém, a espécie mais comum foi staphylo coccus epidermidis, atualmente considerada patogênica oportunista e não mais sapröfita $(5,85)$.

No mesmo ano, Härtling (82) verificou a qualidade de comprimidos e granulados a base de drogas vegetais usados como laxantes, tendo obtido para o primeiro contagens bacteriana e fúngica variando, respectivamente, de $7,0 \times 10^{3}$ a $3,7 \times 10^{4}$ e de 0 a $2 \times 10^{2}$ por grama. Os granulados apresentaram, para os mesmos requisitos, niveis de $8,5 \times 10^{2}$ a $1,4 \times 10^{5}$ e de 0 a $2,5 \times 10^{2} / \mathrm{g}$, respectivamente. Das 7 amostras analisadas 4 apresentaram enterobactérias e, destas, 2 em nivel superior a $100 / \mathrm{g}$.

Na Índia, Nandapurkar e colaboradores (127), em 1985, detectaram espécies patogènicas en comprimidos de una farmácia hospitalar.

Porteriormente, em 1986, Arribas e colaboradores (6) continuaram a análise de formas farmacêuticas sōlidas com 240 amostras, tendo verifi cado qualidade satisfatöria, visto que a maioria delas se mostrou isenta de 
bactërias, sendo que $73(30,4 \%)$ apresentaran bactérias aeróbias e apenas 16 $(6,66 \%)$ ern nivel superior a $10^{3} / \mathrm{g}$. Foram isoladas 18 espécies de Bacillus a partir de 70 amostras $(29,16 \%)$, tendo sido mais frequentes 8 acillus subtilis,

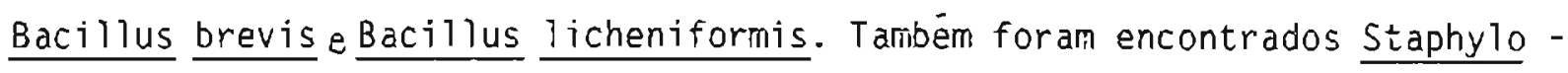
coccus sp. Micracoccus sp. e fungos.

No Brasil, em 1990, O Instituto Nacional de Controle de Quali dade em Saúde (INCQS) iniciou o controle microbiológico de fitoterápicos, visando identificar as bactérias e fungos isolados das diferentes amostras (175).

\subsection{Fadrào Microbiano}

\subsubsection{Padrão microbiano de insumos farmacèuticos}

Os padrões nicrobianos para insumos fitoteräpicos foram ofi cialmente exigidos muitos anos após o enquadramento dos mesmos como insumos farmacēuticos com qualidade farmacopêica. Entre esses, a primeira planta su perior que recebeu atributo de pureza microbiana foi digitalis, que consica da Farmacopéia Americana na sua 18a edição (204), de 1970, enquanto que, na especificação de levedura de cerveja já havia o requisito para limite de contaminante aeróbio mesófilo a partir da $13^{a}$ edição (199). É bem verdade que, no inicio, havia orientação oficial com advertẽncia sobre "auséncia tanto quanto possivel de boiores" (NF XII, 1965) (128), o que também se verificou na USP a partir da $13^{2}$ edição (199) até a 17 (203), tendo anterior mente, apresentado semelhante recomendação: "ausência de emboloramento", na 11 a (197) e 12a (198) edições, respectivamente, em 1936 e 1942.

Na edição seguinte do Formulário Nacional (NF XIII) (129) e a partir da 18a edição da Farmacopéia Americana (204), a expressão foi modifi cada para "drogas vegetais e animais deverầc estar, o mäximo possivel, isen 
tas de microorganismos, sendo que os patogénicos não deverão estar presentes"

Convér lembrar que, o primeiro insumo farmacéutico com especificação relativa à qualidade microbiológica foi a gelatina, pois, em fun ção de sua origen, o limite tolerado foi de $10^{4}$ bactérias totais por grana (USP XII, de 1942) (198). Esta toleräncia foi alterada diversas vezes, ten do passado por $5 \times 10^{3} / \mathrm{g}$, na $18^{a}$ eoiç̧ão; $10^{4} / \mathrm{g}$, na edição seguinte (205) e, finalmente, $10^{3} / g$ a partir da $20^{a}$ (206). Além dessa exigéncia quantitativa havia outro requisito, isto é, ausència de patogènicos especificos numa de terminada tomada de ensaio, sendo que esse aspecto foi igual e gradativa mente mais exigente, pois a tomacia de ensaio de "lú rig ou mienos" (USP XIi) (198) passou para 70 mg (USP XVI) (202) e, finalmente, para $10 \mathrm{~g}$ (USP XVIII) (204).

Inicialmente se impós auséncia de Escherichia coli (USP XII e XIII) $(198,199)$, que foi modificada para "auséncia de coliformes" nas 4 edições seguintes $(200,201,202,203)$, mas que passou a ser reconsiderada na USP XVIII (204). Além disso, iniciou-se a exigència adicional sobre a ausência de Salmonella sp., permanecendo inalterada até a USP XXII $(205,205,207,208)$.

As monografias farmacopéicas incluen requisitos para um ou mais oatogènicos específicos em função da origem da matéria-prima, visando evitar a transmissão de doenças para os pacientes através da terapia medicamentosa. En alguns casos, deve-se efetuar a pesquisá de decerminados gru pos contaminantes (coliformes, enterobactérias) a fini de avaliar a qualida de sanitária envolvida na obtenção e /ou preparo desses insumos.

Neste particular, segundo Bruch (35), as matérias-primas a seren empregadas no preparo de medicamentos de uso oral não devem conter Escherichia coli e Salmonella sp.; aquelas para uso tópico dever: estar isentas de Escherichia coli, Staphylococcus aureus e Pseudomonas aeruginosa. 
Atenção especial foi dirigida às matérias-primas pela Farmacopéia Americana, com a introdução de capitulo sobre "Atributos nicrobioló gicos de produtos farmacèuticos não estéreis", na 18a edição (204), tendo sugerido monitoramento com maior énfase "com relação a matérias-primas de origem animal ou botánica, especialmente aquelas que permitem o crescimento niicrobiano e que não se tornam estéreis durante o processamento subse quente". A auséncia de microorganismos viäveis patogênicos cono Sâlmonella sp.,Escherichia coli, Pseudonionas aeruginosa, Pseudomonas sp. e Staphylo coccus aureus foi considerada atributo desejävel para produto de qualidade adequada.

Na USP XİX (205), o mesmo capítulo incluiu consideração sobre esta categoria de insumos (origen vegetal e animal) de que "podera carregar microorganismos patogénicos não descruídos pelos processamentos posteriores", tendo introduzido, adicionalmente à pesquisa de microorganismos especificos, a contagem de microorganismos viàveis aeröbios totais. Sugeriu-se, inclusive que, os produtos contendo tais matérias-primas deveriam ser rotineiramente testados quanto à presença de Salmonella sp.

Na Farmacopéia Britânica, a partir da edição de 1973 configuram as monografias de digitalis (folha) e de goma adraganta com toleràncias declaradas para a presença de patogénicos específicos.

Analisando a exigenciadesses 2 padrões oficiais ao longo do tempo observâ-se desvinculação entre o grau de contaminação saprófita total e a presença de patogènicos pois, a maioria das monografias exige apenas a pesquisa de parogénicos específicos.

As especificações farmacopẽicas de alguns insumos fitoterāpi cos e farmacotécnicos de origen vegetal, quando observadas sob ponto de vista evolutivo $\hat{a}^{-}$ través das ediçōes, pocie-se dizer que en muitas não houve sequer referên cia sobre a qualidade ricrobiana. Verifica-se tambéri, que houve reciução do número de matérias-primas vegetais, en vista da substituição por principios 
ativos naturais e/ou sintéticos. Em alguns casos, há diferença marcante en tre as duas farmacopéias, seja no aspecto quali ou quantitativo, assim como na época de oficialização destas exigencias. Para digitalis, na fonna bruta, por exemplo, constaram as exigëncias de ausencia de Escherichia coli em $1 \mathrm{~g}$ da tomada de ensaio e de Salmonella sp. em $10 \mathrm{~g}$, na BP 73 (32) enquanto que a Americana, apesar de incluí-la como monografia, não apresentou padrão mi crobiano. No caso de pó, a BP 80 (33) exigiu apenas a ausēncia de Escheri chia coli em $1 \mathrm{~g}$, tendo complementado o requisito com a recomendação para au séncia de Salmonella sp., na úitima edição (34). Ao lado disto, a Farmacopéia Americana exigiu apenas a segunda parte deste requisito, a partir da $18^{a}$ edição (204), com exceção da 19a (205) que não constou da monografia.

No caso de àgar, a exigência de auséncia de Salmonella sp. em log surgiu na USP XVII (204), enquanto que na Farmacopéia Britânica, somente em 1988, constou a recomendação referente a auséncia de Escherichia coli em tomada de $\lg (34)$.

Tanto a Farmacopéia Americana, desde a $20^{a}$ edição (206), quanto a Británica, desde 1932 (30) apresentaram especificações para ipecacuanha na forma de droga bruta e/ou de pó, porén sen requisito para aqualidade microbiológica.

No caso da rauwolfià, a Farmacopéia Britânica não a incluiu entre suas monografias, enquanto que a Americana fêz exigèncias para ausên cia de Salmonella sp. em 10g, na sua edição de 1980 (USP XXI) (207), sendo que para o pó da droga, fez a mesma recomendação a partir da $20^{a}$ edição (206).

Para carvão ativo não há qualquer requisito constando da Farma copéia Británica, porém, a auséncia de Salmonella sp. e de Escherichia co$1 \mathrm{i}$ em tomada de ensaio de log jä configurou na USP XVIII (204).

Quanto aos adjuvantes farmacotécnicos de origem vegetal como o $\begin{array}{lll}\text { amido, o padrão microbiano da Farmacopéia Americana surgiu em } 1970 & \text { (204) }\end{array}$ tendo sido mantido até hoje na USP XXII (208), referindo-se à auséncia de Salmonella sp. e Escherichia coli em $10 \mathrm{~g}$ do pó, ao passo que apenas a última edição da Farmacopéia Britänica (34) tratou desse aspecto, apesar de sua importáncia, tendo recomendado a auséncia de Escherichia coli em $1 \mathrm{~g}$. 
Para goma arábica, os requisitos de pureza microbiana, igualmente aos insumos ativos ou não foram semi-quantitativos e introduzidos a partir da USP XVIII (204), não permitindo a presença de Salmonella sp. em $10 \mathrm{~g}$, ao passo que a $8 P 88(34)$, de Escherichia coli em $1 \mathrm{~g}$ de pó.

Para goma adraganta, a Farmacopéia Britänica fez värias modifí cações no limite de pureza microbiana, desde 1973 (32), quando então exi giu auséncia de Salmonella sp. em $10 \mathrm{~g}$, tendo passado a "ausência de Escherichia coli em lg", na edição seguinte (33) e, finalmente, à somatória dos requisitos anteriores, na edição de 1988 (34). Na Farmacopéia Americana, os requisitos para este insumo foram introduzidos em 1980, na $20^{\text {a }}$ ediçào (206) com recomendação de auséncia de Escherichia coli e Salmonella sp. en log.

Tanto a USP VIII (195) de 1905, UXP X (196) de 1920 até a USP XXII (208) quanto a BP 32 (30) até a BP 88 (34) não apresentam limite microbiano para as seguintes drogas vegetais, embora constem de monografias. Trata-se de cáscara sagrada, aloe, beladona, alcaçuz, ópio, bálsamo de Tolu entre outras. Além disso, verifica-se que são raras as monografias farmacopéicas a apresentarem 1 imite microbiano referente a contaminantes fúngicos $(71,199,200,201,205)$.

com relação à regulamentação brasileira para insumos farmacêuticos de origem vegetal, observa-se a inclusão de padrões microbianos a par tir da 2 edição (71) sendo que para levedura seca configuram limites quan titativos para bactéri as e fungos sendo de $7,5 \times 10^{3}$ bactérias e 50 fungos por grama à semelhança de recomendações da Farmacopéia Americana nas suas $13^{a}(199), 14^{a}(200)$ e $15^{a}(201)$ edições.

Na Farmacopéia Brasileira II (69), não constam os limites para a mesma matéria-prima. A última edição (70), de 1988, por ser apenas parte referente a métodos gerais não inclui monografias.

Em 1980, Lenoble e colaboradores (110) sugeriram normas para as espécies vegetais destinadas ao consumo sob a forma de chá. Para as bactérias aeröbias mesöfilas, o limite era de $5 \times 10^{5} / \mathrm{g}$, enquanto que para fungos, de $5 \times 10^{2} / \mathrm{g}$ e para enterobactérias, de $5 \times 10^{4} / \mathrm{g}$. Adicionalmente, a 
pesquisa de Escherichia coli e Salmonella sp. deveria atender ao requisito de auséncia de $1 \mathrm{~g}$ emtomada de ensaio, sendo que a presença simultänea de estreptococos fecais e clostridium perfringens não seria tolerada, e nem mes mo desse último isoladamente.

Em 1979, o grupo de especialistas da Farmacopéia Belga elaborou mesmo tipo de estudo, a fim de que as drogas vegetais e suas misturasconstas sem da 5a edição sob a denominação de chás (55). Na mesma época, o grupo de estudos da Farmacopéia Européia propós normas menos rígidas para esta cate goria de insumos, com tolerância de até $5 \times 10^{4}$ microorganismos por grama, sem exicenciaspara a pesquisa de microorganismos como pseudomonas aeruginosa e staphylococcus aureus (55).

Em 1983, foi publicada a Nota Técnica Pro Farmacopéia n 190 (134) referente ao controle microbiológico de plantas medicinais, com as de vidas adaptações em relação à Nota Técnica Pro Farmacopéia no 189 (133) relativa ao "Controle da contaminação microbiana em produtos não estéreis", tendo constado os limites, respectivamente, para bactérias aeróbias totais e fungos, de $5 \times 10^{5}$ e $5 \times 10^{4} / \mathrm{g}$. Além de recomendação para a ausência de Escherichia coli, Pseudomonas aeruginosa e Staphylococcus aureus em $1 \mathrm{~g}$.

\subsubsection{Padrão microbiano de medicamentos não estéreis}

Entre as propostas iniciais, a de 1954, da Farmacopéia da Tche coeslováquia $(45,61)$, apresentou limites de contagem total bacteriana para comprimidos e produtos análogos (61). Posteriormente, na Suécia, após os estudos de Kallings e colaboradores (93) surgiu a proposta de limite de até $10^{2}$ bactérias por grama ou mililitro de produto farmacéutico. Esse valor foi a dotado em 1967 pela Junta Médica Real da Suécia em Memorando sobre higiene e produção e controle bacteriológico, na fabricaçào de medicamentos (188). Com isso, esse país passou a ser considerado o de origem das especificações para con trole microbiano de medicamentos não estëreis, dos princípios ativos e adjuvan tes farmacotécnicos (99).

A segunda edição da Farmacopéia Internacional (90), em 1967, recomendava que a contaminação microbiana de medicamentos não estéreis fos- 
se inferior àquela permitida para os alimentos, pela legislaçäo vigente em cada país. Semelhantemente, o critério sugerido pelo Laboratörio de Serviço Nacional de Saúde da Dinemarca (130), en: 1968, foi baseado no fato de que os medicamentos de uso oral não deven causar infecções no trâto gas tro-intestinal, à semelhança de àlirentos. Assin, a preocupação esteve vol tada para a comprovação da ausencia de salmonelas e shigelas.

De forna geral, verifica-se que o estabelecimento inicial de normas microbiológicas para medicanentos de uso orai foi inspirado naqueles existentes para alimentos $(120,166)$. Dony e Gërard (61), jä era 1968, dividiran os medicamentos em categorias diferentes, tendo equiparado os produtos farmacéuticos de uso oral aos alimentos semi-conservados, razão peìa qual os autores emfatizarari, igualmente, o aspecto sanitiário recoriendando a ausencia de microorganismos indicadores de contaminação fecal, de pătogénicos (especialmente salmonelàs e shigelas), bern cono daqueles responsäveis por toxi-infeções. Recomendaran carga bacteriana sotal inferior a $10^{4} / \mathrm{g}(\mathrm{mL})$, baseando-se en padrões para leite pasteurizado $\left(3 \times 10^{4} / \mathrm{g}\right)$, leite medicamentoso $\left(1,5 \times 10^{4} / \mathrm{g}\right)$ e al imentos semi-conservados $\left(10^{4} / \mathrm{g}\right)$.

Eri 1969, Penso (149) propós padrões mais rígidos do que os de Dony e Gérard (6)), tendo limicado a carga viável total para 50/g (n) no caso de raropes e elixires; $10^{2} / g$ (ril ) para formas farmacêuticas sölidas, porém mantendo o mesmo limite do padrão anterior para cápsulas gelatinosas.

Segundo Westwood (213), eni 1971, os padröes para contagen total de bactérias viáveis en certos alimentos, aceitos em muitos países, são de no mäximo $10 \%$ apesar da vigencia de niveis 5 a 10 vezes mais tole rantes que o limite anterior. Em função disto acredita ser razoável o de $10^{4} / \mathrm{g}$, indicando, assim, o padrão de qualidade sanitäria, una vez que as na térias-primas de uso farmacéutico seriam, provavelmente, menos coniamina das que aquelas alimenticias.

No Brasil, o ütimo padrão microbiológico vigente para alimentos foi estabelecido pela Divisão Nacional de Vigilancia Sanitária de Ali- 
mentos (28), em 1987, tendo sofrido algumas correções (2S) e dá ênfase à de terminaçāo de microorganismos patogénicos, além de requerer para "leite e produtos de laticinios", por exemplo, contagen padrão em placa de até $3 \times 10^{5} /$ m (leite pasteurizado tipo C), sendo interessante notar que a to leräncia máxima para bolores e leveduras é de $5 \times 10^{3} / 9$ parâ produtos de infusão, sementes cruas ou torradas, especiarias eri pö, sendo, nesse caso, a determinação desses microoorganismos preferencial à contagen bacteriana. Com relação ao padrão brasileiro, a última edição dô farmacopéia (70) incluiu o método geral de anälise para "produtos que não necessitam cumprir corn o teste de esterilidade". Como não houve atualização sinulizanea cas mo nografias e dos métodos gerais, o Brasłl carece de limites de tolerância para contagem total de viáveis em medicamentos, embora existatpara insumos.

Na Inglaterra, atravēs de suã farnacopéia, edição de 1973 (32), pode-se observar conduča similar a outros páises anteriormenî mencionados, visto referir-se à pesquisas de patogénicos especificos cono Escherichia $\underline{\text { coli }}$, Pseudomonas aeruginosa e Salmonella sp., porém, salientando a não obrigatoriedade desses testes.

En 1971, en Simpósio realizado en Londres (35) sobre o controle microbiclógico de medicanentos e cosméticos, muitos especiaistas haviam renovado a importáncia da necessidacie de pesquisa de algumas espécies especificamente consideracias como indesejäveis nesses produtos. Chegou ao exiremo exagero, segundo Evans (68), para a exigència de ausēncia de endotoxinas.

Em 1972, a Feceração Farnacéutica Internacional (FIP) opresen tou relatório sobre os problenas gerais inerentes à pureza microbiana em medicamentos não estéreis (47). Este docuriento, incluindo os mëtodos de análise, foi publicado en vários idionas $(39,165,214)$. Em 1976, no seu seguncio relatörio, foram apresentados os niveis de toleráncia da contaminação microbiana, em função da categoria de nedicanentos. Esta classificação 
teve como base a proposta sugerida por Dony $\{62\}$, que levou em considera ção o risco da presença de diferentes espécies microbianas eñ função da ad ministração. A categoria 7 , subdividida en grupos la e 1b, referia-se, respectivamente, aos produtos estéreis e àqueles de uso tópico. Neste segundo grufo (medicamentos de uso oftálmico e aqueles destinados à aplicação em cavidades normalmente livres de microorganismos, bem como queinaduras e ulcerações graves) o requisito era de que não houvesse contaninante viável em $7 \mathrm{~g}(\mathrm{~mL})$ do produto. Na categoria 2 foram enquadrados aqueles de uso tópico, sobre pele e lesōes, nas mucosas do nariz, garganía e ouvido, tendo sido recomendado o linite máximo de $10^{2} / \mathrm{g}(\mathrm{ml})$ de bactérias aeróbias, além da ausência de encerobactérias, Pseudononas aeruginosa e Staphy lococcus aureus em $1 \mathrm{~g}(\mathrm{~mL})$ do produto. As outras especialidades farmacéuticas, pertencendo à categoria 3 , onde se encontrari os medicamentos de uso oral e outros, deverian apresentar carga bacteriana inferior a $10^{3}$ a $10^{4} / \mathrm{g}$ (m) e füngica, $10^{2} / \mathrm{g}(\mathrm{mL})$, alëm da obeciência à auséncia de Escherichia colí, Pseudononas aeruginosa e staphylococcus aureus eri $1 \mathrm{~g}$ (ril) e conter, no mäximo, $10^{2} / \mathrm{g}$ de outras enierobactérias. 0 linite bacteriano máxino fun damentou-se em caso de presença de componentes constituindo fonte inevitável de contaminação cujo nümero não fosse reduzido durante o processo, subentendendo, portanto, a presença de matéria-prima de fonte natural.

No mesmo ano, Smart e Spooner (183) questionaram o padrão sueco eni vigor que estabeleciz a toleräncia de até $10^{2}$ microorganismos por grama, fazendo ressalva quanco ao "fator tempo", isto é, o momento no qual o produto deveria estar en conformidade ao requisito, se imediatamente apös o término da manipulação ou meses ou anos após este instante. Ailéri dis to, outro aspecto diretanente relacionado do tempo cizia respeito ao tipo de produto, se capaz de manter a viabilidade dos coniarsinantes iniciais ou, ainda, promover o crescimenco dos mesmos.

A preocupação considerada por Buogo e Ratti (40), quando do 
estabelecimento de limite para contaminante tóal cono sendo $2 \times 10^{2} / \mathrm{g}$ (nL), relacionava-se com o controle dos microorganismos patogénicos, devendo basear-se em critério probabilistico afeto a momentos especificos da produção, como por exemplo, no caso de manipuladores apresentarem alguma doença impecciosa.

Ao lado dos inümeros padrões nacionais, tamoém, a comissão da Farmacopéia Européia, encarregada de estudos sobre a contaminação microbie na ern medicamentos, propos o seu muito semelhante ao da FIP, en 1973 (191). Mais tarde, em 1985, essa mesma farmacopéia incluía a metadologia para con trole microbiológico de medicamentos, porém, sen haver definição dos limites de toleräncia para os producos acabados (8).

En 1975, foi publicada a proposía de qualidade microbiana da Sociedade Italiana de Ciēncias Farmacêuticas (SISF) (60), com conteúdo semelhance ao da FIP, coni diferenças no nivel de exigência. Nestâ, os produtos de aplicação tópica tiveram o limite de carga viävel total bacteriana ou füngica 1 imitada en $10^{2} / \mathrm{g}(\mathrm{mL})$ e ausência de staphylococcus aureus, Pseudomonas aeruginosa e Escherichia coli, seri a exigencia para enterobac térias. Para os produtos de uso oral, o limite para carga bacteriana foi de $10^{3} / g$ (nh), enquanto que para fungos foi igual ao da FIP.

Em 1977, o Laooratório Nacional de Saúde da França (151) propós normas de pureza microbiológica de acordo com as formas farmacéuticas, diferindo da FIP em alguns aspectos. Acrescentou a exigéncia para ausencia de estreptococos fecais e clostridios sulfito-radutores nos produtos correspondentes à categoria 2, além dos mencionados pela FIP (Scaphulococcus aureus e Pseudomonas aeruginosa). Com relação à categoria 3 , no tocante à pesquisa de patogénicos específicos exigiu-se a ausēncia de enterobactérias, Pseudomonas aeruginosa, Staphylococcus aureus, estreptococos fecais e cloæridios sulfito-redutores. 
Outra proposta foi apresentada por Tagliapietra (191), em 1978. Este vincula, no caso da categoria 2 da FIP (47), a pesquisa de patogêni cos especificos com a carga contaminante total, pois, se for baixa (menor que $10 / \mathrm{g}$ (mL)), tanto para bactérias aeróbias mesófilas ou fungos, basta e fetuar a pesquisa de Escherichia coli en ? g (mL) do produto. Porérn, ulira passado este limite, estando entre 10 e $10^{2} / \mathrm{g}(\mathrm{mL})$, a pesquisa de páogéni cos específicos inclui iaribérn staphylococcus aureus e Pseudononas aeruginosa.

Com relação aos produtos de uso oral e outros medicamentos, o 1 imite para carga bacieriana e fúngica é de $10^{2} / \mathrm{g}$ (rall), aincía devendo es tar livre de Escherichia coli em $1 \mathrm{~g}$ (mL).

Caso a contagen bacteriana recaia entre $10^{2}$ e $10^{4} / \mathrm{g}(\mathrm{nL})$ e a fünica até $10^{2} / \mathrm{g}(\mathrm{mL})$, a exigència complementar é de que esteja 1 ivre de Salmonella sp. e Escherichia coli enl $1 \mathrm{~g}$ (riL), alëri de toleräncia de enterobactérias até $10^{2} / g(\mathrm{~mL})$.

Mais recentemence, em 1982, Ringertz e Ringertz (169) recomendaram para produtos de uso tópico o mesmo limite dâ FIP parà contagen total e núnero grande de espécies indesejäveis alén das exigidas pela FIP, a saber: Serratia marcescens, Klebsiella sp., Pseudononas putida, Pseudomonas multivorans (cepacia), clostridium perfringens, Clostridium. tetani, Clostridium novyi, Aspergillus sp. a Candida albicans. Para produtos de uso oral reconendân ausencia dos germes responsäveis por infecções al imentares cono salnonelas, shigelas e Staphylococcus aureus enterocoxigenica, ben como fungos produtores de toxinas. Consideraram que, a exclusão de virus pode ser deduzida quancio da ausencia de Escherichia coli cono indicacior de contaninação fecàl.

Quando o produto contivesse corticosieróides o mesmo deveria ser aprovado pelo teste de esterilidade, considerando o aunento de suscepcibilidade a infecções por parte dos pacientes (169). 
Os padrões farmacopéicos americanos e britãnicos para fitoterá picos constituindo forma farmacêutica forari semi-quantitativos, assim como para as respectivas drogas vegetais, embora haja padrões quantitativos para alguns medicamentos de uso oral.

Tanto para cápsulas e comprimidos de digitalis, a Farmacopéia Americana constou de limite microbiano a partir da $20^{\text {a }}$ edição (206), recomendando auséncia de salmonelas em $10 \mathrm{~g}$ de produto. Enquanto que a BP apre sentou monografias para os comprimidos, nas edições de 1953 (31) e de 1973 (32) en diante, porér., sem qualquer menção a padrão microbiológico.

A monografia de rauwolfia sequer foi incluida nesía mesma farmacopéia, diferentenente da Americana cuja exigéncia para os comprimidos constituídos desta mesma droga foi a ausencia de salmonelas em $10 \mathrm{~g}$ de pro duto, à partír da 20 à edição (206).

Para ipecacuanha, na forma de xarope, a partir da USP XX (206) foi recoriendada auséncia de Escherichia coli para tomada de ensaio cie 10 $\mathrm{mL}$. En contrapartida, não houve qualquer referencia a forma farmacéúcica contendo esta droga, na Farmacopéia Brituannica.

Mesmo na década de 80, ainda não se contou coril paórão ünico de pureza microbiana para produtos farmacêuticos não estéreis, o que levou muitas empresas a elaborarem as suas pröprias especificações, baseando-se no histórico de cada produto $(12,166)$.

Em 1985, a Farmacopéia Italiana adotou critérios eril dois niveis, isto é, caso o limite pré-fixado fosse superado, no tocante à contagem total, a avaliação deveria serampliada. Para pomadas e outros de uso tópico o linite pré-fixado para bactérias aeróbias mesófilas foi de $10 / \mathrm{g}$ (nL) sem exigéncia para pesquisa de espécies específicas. Não havendo obeciência para com este limite, o segundo critério seria anpliado para $10^{2} / \mathrm{g}$ (mL) no caso de carga bacteriana e para fungos, de no riäximo $10 / g$ (mL), 
além da pesquisa de Pseudomonas aeruginosa e Staphylococcus aureus com a ausēncia dos mesmos em $1 \mathrm{~g}$ (mil). Para medicamentos de uso ora] como cápsulas, comprimidos, elixires, xaropes, etc, o limite bacteriano seria cie 10/s (mL), sern necessidade para outras pesquisas. Entretanto, não havendo cumprimento deste requisito, a exigencia subsequente seria não ulîrápassar os seguintes limites: $10^{3}$ a $10^{4} / \mathrm{g}(\mathrm{mL})$ de bactérias aeróbias mesöfilas, $10^{2} / \mathrm{g}$ (nL) de fungos, $10^{2} / g$ ( $\mathrm{LL}$ ) de enterobactérias, auséncia de Escherichia coli en $1 \mathrm{~g}(\mathrm{~mL})$ e de sajmonelas em $10 \mathrm{~g}(\mathrm{~mL})(8)$.

Aié 1986, não havia critérios oficializados para chás, na Fran ça. Cortez e colaboradores (49) sugeriram considerä-los como forria final de consumo, razão pela qual o nivel de qualidade deveria equivaier ao de medicamento de uso oral. Porér, na auséncia de publicação oficial, vários padrões microbiológicos foram propostos e adotados pelas industrias farmacèuticas.

Diante desta diversidade de padrões, apesar de não configurar limite numérico único, fica ben evidente a preocupação quanto à não ŝransmissão de doenças aos pacientes como decorrencia do tratamenco medicamento so, bem como da mianutenção da estabilidade do próprio produto, evitando-se a sua deterioração durante o prazo de validade e consequentanente oferecen do segurança aos seus usuários. Desta forma, conforme já mencicnado por Baird (12), en 1986, os fabricantes devem estzbelecer os critérios de qualidade para seus produtos em função das macérias-primas integrantes da för mulä, e o seu potencial de carga microbiana contaninante, conpactitilizando com o processo de manipulação, a fim de que a eficácía terapéutica e inocuidade sejam garantidas aos pacientes.

\subsection{Metodologia de avellaçäo}

Considerando a qualidade dos medicamentos näo estéreis quanto 
à sua pureza microbiológica, tornou-se necessäria a padronização e adequação das técnicas bacteriológicas clässicas, de forma que esses riécodos ana liticos fossem confiăveis e reproduciveis.

Tendo em vista o padrão de pureza microbiana desejāvel gara gã neros alimenticios e a semelhança desses com medicamentos de uso oràl (51), a metodologia de avaliação da qualidade ricrobiolögica dos primeiros serviu de modelo para o estabelecimento daquela relativa aos produtos farmacèuticos e afins $(120,170)$.

Os métodos empregädos visan detectar o nünero total de sapróf sas viäveis e identificar alguns patogênicos especificos, con à finaiidade de avaliar a quălidade microbiana. 0 isolanento dâs espécies indesejáveis representadas principalmente por aquelas indicadoras decontaminação fecal e/ou virtualmente patogênicas indica as condições sanitärias impröprias. Cori is to, a verificação da purezâ riicrobiana de medicamentos não estéreis e insu fros farmacêuticos fundamenta-se basicamente ai. 2 aspectos $(23,47,53,54,51$, $73,93,101,113,120,133,139,140,145,151,164,184,210)$. Un, da evaliação das condi ções gerais, através da quantificação de rificroorganismos viäveis e outro, da pesquisa de microorganismos especificos, conforme mencionado anierior mente, con a sua quantifíicação ou não. Portaño, a metodologiê baseia-se en técnicas bacteriológicas rotineiras, coni al gumas adaptaçces, quando necessárias $(9,49,55,73,82,95,110,131,177,213)$.

os compenóios oficiais elou farriacopéias dirigirara a atenção, inicialmente, à contariinação microbiana c'e insumos farmacéuticos.

A prineira edição da Farmacopéia Anericana a apresentar métodos de anälise microbiológica foi a 12a (198), en 1942, pära gelatina, ten do descrito a técnica para coníagen bacteriana cotal e a pesquisa de Esche richia coli. Na edição de 1947 (199), foi introduzicia a netodologia especí fica, na monografia de leveára seca, abrangendo contagem fúngica, fato que se repete até a 150 edição (201). Porén, sonente en 1970, na 18a edição 
(204), constou o capītulo "Teste de limite microbiano", descrevendo as téc nicas microbiológicas para a contagem total de microorganismos aeróbios viäveis e para a pesquisa de espécies microbianas especificas, como Escherichia coli, Salmonella sp., Siaphylococcus aureus e Pseudomonas aeruginosa., cujos 1 inities configuravan en algumas monografias.

Na Inglaterra, a metodologia de análise para medicamentos não estéreis foi incroduzida, somente na edição de 1973 (32) da Farmacopéia Brituānica sob a denominação "Teste para a con'caminação microbiana", não hạ vendo obrigatoriedade de seu uso em específico, porér com a ressalva: "quando métocios alternativos são empregados nas provas de controle deve ser usado numero e tipo de microorganismo especificacio", isto é, Escherichia coli, Salmonella sp. e Pseudomonas sp.

A Farmacopéia Británica apresentou iendéncia para a anālise se mi-quantitâtiva e apenas sua últina edição de 1988 (34) inciuiu a concagen. de microorganismos aeróbios viáveis totais.

Parícularmente, con relação a insurios ou medicamentos fitoterápicos e adjuvantes fámacotécnicos de origen vegetal, ambas as famaco péias apresentam especificações, cujo cumpriniento ou não deve ser mediante a anālise conforme a metodologia geral descrita para medicamentos não esté reis.

Apesar da subdivisão dos produtos farmacéuticos em trés catego rias, a Federação Farmacéutica Internacional (FIP) (4.7) apresentou netodologia semelhante àquela da Farmacopéia Americana. Constou, também, a conta gem de fungos e a pesquisa de enterobactérias, alérn de Escherichia coli. A mesma foi recapitulada por Devleeschouwer e Dony (54), em 1979, tendo sido empregada na análise de fitoterápicos $(55,82)$.

Com relação ao controle microbiológico de fungos, a Fâmacopéia Americana apresentou fitem "Contagen total combinada de bolores e leveduras" 
a partir da $21^{\text {a }}$ edição (206), eri 1980, enquanto que somente a BP 88 descreveu procedimento senelhante.

Em contrasie, ao estudaren a qualidade de fitoterápicos, muitos autores pesquisaran a contaminação fúngicà $(9,49,55,82,95,110,114,131$, 140,17i,2131, enpregando métodos similares entre si.

A Farmacopéia Brasileira, na sua 2a edição (71), introduziu a metodologia para "exame bacteriológico da gelatina" incluindo contageri total e pesquisa de coliformes, alérn da contagem bacteriana e fúngicâ, na es pecificação de levedura seca. Porém, somente, na 4 a edição (70), en 1988, foi apresentado o procedimienco analitico para controle microbiológico de medicamentos não estéreis, através dos capĩtulos "Contagen de ricicroorganis mos viäveis en produtos que não necessitar cumprir com o teste de esterili dade", tratando da quantificação de bactérias e fungos e "Método geral Pa ra pesquisa e identificação de patógenos", sendo estes os mesmos indicados pela USP (204). 
4. MATERIAL E MÉTODOS

4.1 Material

0 presente estudo foi realizado com fitoteräpicos constituindo especialidacies farmacéuticas sob a forma sölida, abrangendo comprimido, cáp sula e pó. A amostrageni das mesmas foi efetuada em farmácias, drogarias, lojas de produtos naturais e supermercados da cidade de São Paulo, no periodo de setembro de 1987 a julho de 1989, totalizando 84 loces, produzi dos por 20 fäoricantes estabelecidos eñ 6 escados brasileiros: São Paulc, Santa Catarina, Mato Grosso, Rio de Janeiro, Rio Grande do Sul e Pará. Assim a amostragem abrangeu 21 comprimidos, 48 cápsulas e 15 pós, em que con figuram 17 espécies vegetais.

4.2 Mëtodos

4.2.1 Apresentação comercial das amostras

4.2.1.1 Droga vegetal

A classificação e a frequéncia de ocorreñcia da espécie vegetal integrante da förmula foram baseadas en informações contidas na bula, no rótulo elou no cartucho do produto.

\subsubsection{Forma farmacéutica}

Os produtos amostrados foran subdivididos en compriríido, cápsulà e pö, verificando-se a presença ou não de denominação correspondente no material iripresso da embalagen. 
$4.2 .1 .3 \mathrm{Bu} 1 \mathrm{a}$

observou-se o acompanhamento ou não da bula como folha impres sa contendo as informações pertinentes ao produto, conforme a legislação eri vigor $(24,25)$, dentro da eribalagem secuncária ou como recurso alternati vo através de informações inpressas tanto no rötulo da embalagem primária corio na própria embalagen secundäria.

\subsubsection{Identificação do ciclo produtivo}

Foi verificada, en cadá apresentação farmacéutica comercial, o cumprimento às exigëncias legais $(24,25)$ no tocance à identificação co ciclo produtivo, através da informação traduzida por data de fabricação, pra zo de validade e número de lote.

4.2.1.5 Embalagens primária e secundäria

A embalagera primária foi classificada quanto ao tipo e natureza, enquanto que a secundária, quando presente, quanto à sua nácureza.

4.2.1.6 Responsävel tëcnico

Verificou-se, conforme a legislação sanitária vigente $(24,25)$, a inscrição do nome do responsável técnico, no material impresso.

\subsubsection{Qualificação legal}

0 cumprimento às exigéncias legais quanto ao registro do produ to em örgão de vigiláncia sanitária foi verificado no material inapresso de cada apresentação farmacéutica. 


\subsubsection{Outras informações}

Verificou-se a presença de dizeres como "alimento dietético", "complemento nutritivo", "produto natural" e de afirmaçōes quanto à ausēncia de toxicidade, além da inclusão do nome cientifico da aroga, discrininação do conteúdo em droga por unidade de forma farmacêutica.

\subsubsection{Tratamento e tomada de ensaio das amostras}

Foi efetuada a limpeza e desinfecção externa da embalagem pri mária, antes da sua abertura, com algodão embebico em etanol a $70 \%$ ( $\mathrm{v} / \mathrm{v}$ ) (46). Todo o procedimento analitico obedeceu às condições assépticas, com uso de utensilios, vidrarias e meios de cultura previamente esterilizados. As amostras foram preparadas conforme a forma farmacêutica $(5,40,146)$ e as caracteristicas fisicas $(37,47,133,208)$.

\subsubsection{Comprimidos}

Foi determinado o peso riédio de 10 unidades. Trituraram-se värias delas em gral esterilizado e a tomada de exatamente $5 \mathrm{~g}$ do produto foi efetuada em erlenmeyer de $100 \mathrm{~mL}$. Após a adição de $45 \mathrm{~mL}$ do diluente (solu ção fisiológica contendo $0,5 \%(p / v)$ de polissorbato 80$)$ e agitação manual obteve-se a suspensão do pó, correspondente à diluição $10^{-1}$.

\subsubsection{Cápsulas}

Determinou-se o peso médio das cápsulas cheias. A tomada de en saio en número de cápsulas foi baseada neste dado, de modo a aproximar de 5,0 g. 0 volume do diluente foi ajustado para obter a diluição correspon dente a $10^{-1}$, como no caso dos comprimidos. A dissolução da gelatina foi 
acelerada mediante aquecimento da mistura em banho de àgua, a $40-45^{\circ} \mathrm{C}$, durante 10 minutos, seguido de agitação manual.

4.2.2.3 Pós

A preparação da diluição $10^{-1}$ foi segundo a técnica descrita para comprimidos (ítem 4.2.2.1).

4.2.3 Determinação de contaminantes viáveis totais

4.2.3.1 Determinação de bactérias aeröbias mesófilas viáveis totais

4.2.3.1.1 Técnica de tubo múltiplo $(34,47,70,133,208)$

A partir da amostra diluída a $10^{-1}$, segundo o item 4.2.2, efetuaram-se diluiçōes seriadas decimais até $10^{-\epsilon}$, com auxilio de $9 \mathrm{~mL}$ de solução fisiológica estéril. A partir de cada ume das diluições foram transferidas alíquotas de 1 rit para réplica de 3 tubos contendo 9 mil de caldo de caseina-soja (Difco).

Os tubos foram incubados em estufa à temperatura de $36 \pm 1^{\circ} \mathrm{C}$, por 72 horas, com observaçāo macroscópica dos mesmos a cada 24 horas, anotando-se os dados positivos para o aparecimento de turvação como resultado do desenvolvinento bacteriano. Após 72 horas de incubação todos os tubos foram agitados manualmente e sempre que houve dúvidas na diferenciação do crescimento bacteriano e turvação inerente à amostra en suspensão, procedeu-se à confirmação. Para isto, aliquota de $0,1 \mathrm{~mL}$ foi inoculada para 4 ril de câldo caseína-soja, seguida de incubação nas riesmas conơições, duran te 24 horas.

Quando a triplicata de tubos correspondente $\bar{a}$ diluição $10^{-6}$ 
acusava crescimento em todos, o reteste foi efetuado com diluições decimais maiores até que resultassen tubos positivos e negativos dentro da réplica. Os dados obtidos, com ou sem subcultura, serviran para a determinação da estimativa de contaminação por grama de produto, através da Tabela do Número Mais Provável (NMP).

4.2.3.1.2 Técnica de ágar fundido $(34,47,70,133,170,208)$

As suspensões diluidas das amostras, preparadas conforme 0 item anterior, serviram para este ensaio. Aliquotas de 1,5 e 1,0 mh foram transferidas para duplicâta de placas de Petri e homogeñeizâdas con cerca de 20 ril de àgar caseina-soja $(0 \mathrm{ifco})$. As condições de incubação foram idénticas às do procedimento anterior, efectuando-se contagem diária de colō nias, até 72 horas.

Para efeito de cálculo foran selecionadas as placas cujo número de colónias variou de 30 a 300 , em que o valor médio foi nultiplicado pela recíproca da diluição correspondente. Apenas 3 amostras escolhidas ao acaso, foram analisadas através desta técnica.

4.2.3.2 Determinaça de leveduras e bolores viáveis totais

4.2.3.2.1 Técnica de tubo mültiplo $(34,47,70,208)$

0 procedimento analitico foi o mesmo aplicado para as bactérias. 0 meio de cultura utilizado foi caldo Sabouraud-cextrose (Difco), acrescido de tetraciclina $(0,01 \%)$ após a autoclavaçãó sob a forma de solução aquo sa $(0,2 \%)$ esterilizada por filtração em membrana de 0,22 um. Os tubos foran incubados en estufa a $20-25^{\circ} \mathrm{C}$, por 7 dias. Tanto a turvação como a pre sença de hifas foi considerada resposta positiva para fungos. No primeiro 
caso, foi efetuada a confirmação da natureza da turvação pela observação micromorfológica do material corado pelo Gram.

A estimativa cia carga viável foi segundo a Tabela do Nünerc Mais Provävel.

Nos casos em que a subcultura foi necessäria empregou-se a mes ma técrica do f́tem 4.2.3.1.1, utilizando o caldo Sabouraud-dextrose acrescido de tetraciclina.

4.2.3.2.2 Técnica de àgar fundido $(34,47,70,133,208)$

0 procedimento analítico foi idéntico ao aplicado para a conta gem de contaminantes bacterianos, diferindo no tocante ao meio de cultura, pois, aliquotas de $7 \mathrm{~mL}$ das diluiçöes correspondentes a $10^{-1}$ a $10^{-3}$ foram homogeneizadas com àgar seletivo para fungos (Biobrás). Este meio de cultú ra contén $400 \mathrm{mg} / \mathrm{L}$ de cicloheximida e $50 \mathrm{mg} / \mathrm{L}$ de cloranfenicol. A incubação foi conforme o íten 4.2.3.2.1. A confirmação das colōnicas duvidosas, com vistas à diferenciação com o crescimento bacteriano, foi feita através de esfregaço do material e coloração de Gran. Selecionaram-se as placas contendo até cerca de 100 colónicas para efetuar o cálculo do número total de viàveis por grama de amostra.

\subsubsection{Determinação de esporos de bactérias aeróbias mesöfilas $(146,194)$}

Alíquota de $10 \mathrm{mit}$ da diluição $10^{-1}$ das amostras, contida em tú bo de ensaio, foi aquecida en banho de äqua, a $80 \pm 1^{\circ} \mathrm{C}$, por 10 minutos. A pós resfriamento rápicio da mistura, em áqua fria, até atingir a temperatura ambiente, foi sucessivamente diluida e submetida à anālise, pela técnica do tubo múltiplo, conforre o ítem 4.2.3.1.1. 
4.2.4 Pesquisa de coliformes $(2,52,88,126)$

4.2.4.1 Prova presuntiva para coliformes totais

Serieou-se uma alíquota de $10 \mathrm{~mL}$ da suspensão inicial da amostra, correspondente à diluição $10^{-1}$, en tubo de ensaio contendo $20 \mathrm{~mL}$ de caldo lactose (Merck) de dupla concentração, con tubo de Duhran. Os tubos foram incubados em estufa a $3 \hat{0} \pm 1^{\circ} \mathrm{C}$, corn observação a 24 e 48 horas. Aque les que apresentaram crescimento e produção de gás foram considerados posi tivos para a prova presuntiva.

4.2.4.2 Prova confirmatória para coliformes totais

A partir dos tubos positivos da prova presuntiva inoculou-se $\underline{u}$ ma alçada para tubos contendo $9 \mathrm{~mL}$ de caldo lactose-bile-verde brilhante (Difco), com tubo de Duhran. Após incubação dos subos, em condições idênti cas às prova presuntiva, foran considerados positivos aqueles que apresenEaram crescimento e produção de gás neste meio de enriquecimento seletivo.

4.2.4.3 Prova confiratória para coliformes fecais

A partir dos tubos positivos da prova confirmatória para coliformes totais foi inoculada uma alçada para tubo contendo $\&$ mL de caldo EC (Difco), com tubo de Duhran. A incubação foi em banho de água, a 45,0 \pm $0,5^{\circ} \mathrm{C}$, por 24 horas, considerando-se resposta positiva quando havia turvação e formação de gás. 
4.2.4.4 Prova confirmatória para Escherichia coli

4.2.4.4.1 Isolamento seletivo

A partir dos tubos positivos da prova confirmatória para coliformes fecais foi feito repique em estria, na superficie do ágar eosinaazul de metileno (Biobrás). Após a incubação das placas por 24 horas a 35 $\pm 7^{\circ} \mathrm{C}$, as colonias suspeitas foram confrontadas com a descrição da literatura, bem como com a cepa padrão de Escherichia coli UC 677, repicada e in cubada en condições idênticas.

4.2.4.4.2 Identificação micromorfológica

As colònias foram repicadas em àgar caseina-soja inclinado e incubadas em condições idênticas às do isolariento seletivo. 0 crescimento resultante, após esfregaço e coloração de Gram, foi observado micrốcopicamente, considerando-se positivo quando se tratava de bacilos Gran-negati vos, não esporulados.

4.2.4.4.3 Confirmação da fermentação de lactose

As colônias suspeitas foram repicadas para caldo lactose contendo tubo de Duhran. A liberação de gás e crescimento após a incubação dos tubos a $36 \pm 1{ }^{\circ} \mathrm{C}$ durante 24 a 48 horas foi considerada prova positiva.

4.2.4.4.4 Prova do IMViC

As colónias suspeitas, isoladas seletivamente e confirmadas co mo tịpicas em funçäo dos 2 testes anteriores foram subrnetidas às provas bioquímicas, comparativamente à cepa padrão. 
4.2.4.4.4.1 Teste do indol

Foi feito o repique do crescimento resultante em àgar caseinasoja inclinado para tubo contendo $5 \mathrm{~mL}$ de água peptonada. Após a incubação do mesmo durante 24 horas a $36 \pm 1^{\circ} \mathrm{C}$, a metade do liquido foi agitado com $1 \mathrm{~mL}$ de clorofórmio. Uma vez separada a fase clorotórmica foi adicionado, com cuidado e pela parede o tubo, $0,5 \mathrm{~mL}$ de reativo de Erlich. A prova foi considerada positiva quando a canada clorofórmica apresentou coloração ver melha. Caso conträrio, o teste foi repetido após a incubação de mais 24 ho ras.

4.2.4.4.4.2 Teste de vermelho de metila

0 crescimento resultante em àgar caseina-soja inclinado foi $i$ noculado em $5 \mathrm{~mL}$ de caldo de Clark e Lubs, seguido de incubação a $36 \pm 1^{\circ} \mathrm{C}$ por 72 horas. Pela adição de 5 gotas do indicador vermelho de metila a pro va foi considerada positiva quando houve o desenvolvimento imediato de coloração avermelhada estável. A prova foi repetida com culturas incubadas durante 4 a 5 dias quando a coloração foi alaranjada, indicando resposta fracamente positiva.

\subsection{Prova de Voges-Proskauer}

o caldo de Clark e Lubs, inoculado como no teste anterior, porém incubado por 24 a 48 horas, a $36 \pm 1{ }^{\circ} \mathrm{C}$, serviu para esta prova. Cerca de $1 \mathrm{~mL}$ da cultura foi transferido para um tubo, seguida de adição de 0,6 $\mathrm{mL}$ de solução de alfa-naftol a $5 \%$ e $0,2 \mathrm{~mL}$ de solução de hidróxicio de potás sio a 40\%, com agitação após cada adição. O não desenvolvimento de coloração avermelhada foi considerado prova posiıiva para a presença de Escherichia coli. 
4.2.4.4.4.4 Prova de utilização do citrato

0 crescimento resultante em àgar caseina-soja foi repicado para ágar citrato de Simmons (Difco) inclinado, em picada e estria. A incuba ção do tubo foi em condições idénticas à prova anterior (ítem 4.2.4.4.4.3). 0 não desenvolvimento de coloração àzul intensa e/ou crescimento no trajeto da picada e na superficie foram sinais considerados prova positiva para Escherichia coli.

4.2.5 Pesquisa de salmonel1a sp. $(7,34,160,208)$

4.2.5.1 Enriquecimento não seletivo

Uma tomada de ensaio de $5 \mathrm{~g}$ de amostra foi homogeneizada com $45 \mathrm{~mL}$ de caldo lactose (Merck), seguida de incubação em estufáa, a $36 \pm 1^{\circ} \mathrm{c}$, durante 24 a 48 horas.

4.2.5.2 Enriquecimento seletivo

Aliqquotas de $1 \mathrm{~mL}$ de suspensão resultante do enriquecimento não seletivo foram inoculadas em $10 \mathrm{~mL}$ dos caldos tetrationato (Difco) e selenito-cistina (Difco) e incubados em estufa, durante 24 horas, a $36 \pm 1^{\circ} \mathrm{C}$.

\subsubsection{Isolamento de identificação}

A partir do crescimento obtido em enriquecimento seletivo fizeram-se repiques en estria; na superficicie do ärar sulfito de bisnuto (Difco) e co áaar verde brilhante (Difco). As condiçres te incubaçãa foram iguais às do enriquecimento seletivo e as colónias suspeitas foran repicadas, em picada e estria para àgar-ferro-trí plice açúcar (Difco) inclinado e àgar ferroulisina (Difco) inclinado. Os 
tubos foram incubados em estufa a $36 \pm 1{ }^{\circ} \mathrm{C}$ por 24 e 48 horas, respectiva mente.

As reações bioquímicas, bem como as etapas anteriores de isola mento seletivo foram confrontadas con a descrição da literatura, além do acompanhamento pela cepa padrão de Salmonella thyphosa ATCC 6539.

Procedeu-se à observação microscópica, após coloração de Gram do crescimento cuja resposta bioquīica indicou reação positiva, a firi de confirmar a presença de bacilos Gram-negativos.

\subsubsection{Estimativa de Escherichia coli}

As amostras cujas provas do 1 tem 4.2 .4 .4 indicaram resposta po sitiva para Escherichia coli foram submetidas à análise quantitativa pela técnica do tubo mültiplo.

Prepararam-se diluições seriadas decimais até $10^{-4}$ tendo-se prosseguido com a técnica analítica do item 4.2.3.1.1 empregando-se o caldo lactose (Merck) e a incubação a $36 \pm 1^{\circ} \mathrm{C}$ por 48 horas.

Repicou-se $1 \mathrm{~mL}$ do crescimento con resposta positiva para $5 \mathrm{~mL}$ de Caldo EC (Difco) con tubo de Duhran, tendo-se incubado a $45,0 \pm 0,5^{\circ} \mathrm{C}$, em banho de água, durante 24 horas. Os tubos com resposta positiva, eli fun ção da diluição correspondente, serviram para a determinação do Número Míis Provävel de Escherichia coli por grana de amostrá. 


\section{RESULTADOS}

\subsection{Apresentação das amostras}

Todas as informações relativas às caracteristicas inerentes à comercialização, qualificação legal e demais inscrições presentes na forma de a.presentação das especialidades fitoteräpicas amostradas encontram-se relacionadas, respectivamente, nas Tabelas I, II III (pg. 51,52,53).

5.2 Determinação de contaminantes viäveis totais

Os valores do Nümero Mais Provável (NMP/g) encontrados nos 84 lotes para bactérias aeröbias mesöfilas, esporos bacterianos e fungos, eril função da espécie vegetal e da forma farmacéutica, constam, respectivamente, das Tabelas IV, V, VI e VIII, IX, X (pg.54,55,55 e 58,59).

A Tabela XII (pg. 61) refere-se à incidencia de bolores, leveduras e de ambos, de acordo com a forma farmacéutica.

A carga de microorganismos viáveis totais (NMP/g) dos lotes correspondentes aos produtores com amostragem mais abrangente encontram-se nas Tabelas XVII (produtor A) (pg. 66), XVIII (produtor 8) (pg. 67), XIX (produtor L) (pg. 68) e XX (produtor G) (pg. 69). Os dados equivalentes, porém, correspondentes a produtores com menor amostragem achám-se na Tabela XXI (pg. 70).

5.3 Pesquisa de patogénicos específicos

5.3.1 Pesquisa de coliformes e de Salmonella sp.

Du total de 84 amostras, 61 acusaram crescimento em caldo lactose e, destas, 40 produziran gás e turvação en caldo lactose-bile-verde brilhante. 
Das 40 amostras repicadas para caldo EC, 13 acusaram crescimen to e produção de gás. Destas, 5 apresentaram reações bioquímicas prelimina res positivas, tendo-se observado colonias suspeitas para Salmonella sp.em àgar ferro-triplice açúcar, diferentemente do àgar ferro-lisina em que as reações foram atīicicas.

As Tabelas VII e XI (pg. 57 e 60) relacionaram a incidéncia dos microorganismos patogènicos específicos pesquisados, respectivamente, com a espécie vegetal e forma farmacéutica das 84 amostras.

Ainda, a verificação da presença de coliformes totais, colifor mes fecais e de Salmonella sp., em função da carga de bactérias aérobias mesóitilas, esporos bacterianos e fungos, consta, respectivamente, das Tabe las XIII, XIV e XV (pg. 62,63 e 64).

\subsubsection{Isolamento e determinação de Escherichia coli}

Do total de 13 amostras que acusaram a presença de coliformes fecais, 5 apresentaram reação confirmatória positiva para o microorganismo, tendo-se verificado colónias típicas em meio de isolamento seletivo lágar eosina-azul de metileno), que foram positivas para a fermentação de lactose e prova do IMViC. A Tabela XVI (pg. 65) relaciona os dados de contagem de microorganismos viáveis para as 13 amostras contendo coliformes fecais, fornecendo, para aquelas positivas para Escherichia coli o resultado da sua determinação quantitativa. 
TABELA I - Relação entre amostragem de fitoterápicos e características inerentes à comercialização

\begin{tabular}{|c|c|c|c|c|c|c|c|c|c|}
\hline \multirow{2}{*}{ DROGA VEGEIAL } & \multirow{2}{*}{ AMOSTRAGEM } & \multirow{2}{*}{ PRODU IOR ** } & \multicolumn{2}{|c|}{ EMBAL AGEM } & \multirow[t]{2}{*}{ BULA } & \multicolumn{2}{|c|}{ IDENT IF I CAÇAOA } & \multirow{2}{*}{$\begin{array}{l}\text { PRAZO DE VAL.IOADE } \\
\text { (anos) }\end{array}$} & \multirow{2}{*}{$\begin{array}{l}\text { IÉCHICO } \\
\text { RESPONSÁNEL } \\
\text { (omissão) }\end{array}$} \\
\hline & & & Primária & Secundária & & $N=\operatorname{lote}$ & Data de fabricaçäo & & \\
\hline ALCACHOFRA & $\begin{array}{l}05 \text { cápsula } \\
01 \text { comprimido }\end{array}$ & $\begin{array}{l}B, B, L, L, N \\
K\end{array}$ & $p, p, p, p, p$ & $\begin{array}{l}-,-, c_{,},- \\
-\end{array}$ & $\begin{array}{l}-,-, r c, r c,- \\
r\end{array}$ & $\begin{array}{l}B, B, L,-,-, \\
k\end{array}$ & $\begin{array}{l}B, 8, \cdots, \cdots \\
k\end{array}$ & $\begin{array}{l}3,3,-,-,- \\
3\end{array}$ & \\
\hline BOLOO & $\begin{array}{l}02 \text { comprimido } \\
01 \text { po }\end{array}$ & $\begin{array}{l}L, L \\
C\end{array}$ & $\begin{array}{l}p, p \\
s\end{array}$ & $\begin{array}{l}c, c \\
f l\end{array}$ & $\begin{array}{l}r c, r c \\
r^{*}\end{array}$ & $\mathrm{c}^{-,-}$ & $c^{-,-}$ & $\ddot{2}$ & \\
\hline CARVÃO HEDICIHAL & 01 comprimido & 1 & s & c & a & - & - & - & \\
\hline CASIANHA DA INOLA & 02 cápsula & $8, B$ & $p, p$ &,-- &,-- & $B, \theta$ & $B,-$ & 3,3 & \\
\hline CATUABA & 03 cápsula & $B, B, M$ & $p, p, b$ & $-, \cdots, c$ &,,$-- \mathrm{a}$ & $B, B, M$ & $B, 8, M$ & $3,5,2$ & \\
\hline CENIELHA ASIÁtICA & 03 cápsula & $B, B, L$ & $p, p, p$ & $-\cdot-, c$ &,,$-- r c$ & $B, B,-$ & $8, B,-$ & $3,3,-$ & L \\
\hline CONFRE I & 01 cápsula & B & $p$ & - & - & B & B & 3 & \\
\hline ISPINHEIRA SANTA & 01 cápsula & B & P & - & - & 8 & B & 3 & \\
\hline ESPIRUILINA & 03 cápsula & $B, B, L$ & $p, p, p$ &.,$-- c$ &,,$-- r c$ & B.B,- & $B, B,-$ & $3,3,-$ & $\mathrm{L}$ \\
\hline rucus & 05 cápsula & $B, B, L, L, N$ & $p, p, p, p, p$ & $-,-, c, c,-$ &,,$-- r c . r c-$ & B,B, , , ,- & $B, B, \cdots,-,-$ & $1,3, \ldots,-$ & \\
\hline GINSENG GRASILEIRO & $\begin{array}{l}02 \text { capsula } \\
01 \text { comprimido }\end{array}$ & $\begin{array}{l}\text { B, B, } \\
\text { L. }\end{array}$ & $\begin{array}{l}p, p, \\
p\end{array}$ & $\begin{array}{l}\because- \\
c\end{array}$ & $\begin{array}{l}-,- \\
-\end{array}$ & $\begin{array}{l}B, 8 \\
-\end{array}$ & $\begin{array}{l}8,8 \\
-\end{array}$ & $\begin{array}{l}3.3 \\
-\end{array}$ & L \\
\hline GINSENG COREANO & 03 cápsula & $A, A, E$ & $p, p, p$, &,$- \cdot c$ & $r, r, a$ & $A, A,-$ & $A, A, E$ & $3,3,-$ & \\
\hline gUVARANá & $\begin{array}{l}06 \text { cápsula } \\
08 \text { comprimido } \\
13 \text { pó }\end{array}$ & $\begin{array}{l}A, A, A, B, L, L \\
C, C, G, G, H, K, K, N \\
B, B, C, C, D, H, H, J \\
J, P, R, S, I\end{array}$ & $\begin{array}{l}p, p, p, p, p, p \\
v, v, s, p, p, v, v, p \\
p, p, s, s, p, p, p, e, \\
f l, f I, p, v, v\end{array}$ & $\begin{array}{l}-,-,-,, c, c \\
c, c,-,,,,-,- \\
-,-, F I, F l,-,,-, c \\
,-,-,,-\end{array}$ & \begin{tabular}{l}
$r, r, r,-, r c, r c$ \\
$-,-,-, \cdots, r, r, r,-$ \\
\hdashline$,-, r^{*}, r^{*}, r, \cdots, \cdots, a$ \\
$r^{*}, r^{*}, r, r, r$
\end{tabular} & $\begin{array}{l}A, A, A, B,-, L \\
C, C,-, G,-,-, K, N \\
B, B, C, C,-,-,-,- \\
-,-, R,-,-\end{array}$ & $\begin{array}{l}A, A, A, B, \cdots \\
\cdots, B, C, \ldots, \ldots, K, N \\
\cdots, \ldots, \ldots,-\end{array}$ & $\begin{array}{l}3,3,3,5, \ldots \\
5,5, \ldots, \ldots, \ldots,- \\
3,3,2,2, \ldots, \ldots, \\
1, \ldots, \ldots,-\end{array}$ & $\begin{array}{l}0, J \\
J, R, S, I\end{array}$ \\
\hline LECIIINA DE SOJA & OS cápsula & $A, B, B, L, O$ & $p, p, p, p, b$ & $\cdots, \cdots, c, c$ & $r,-,-, r c, c$ & $A, B, B, L,-$ &,,,,-++ & $3,3,3, \ldots$ & \\
\hline LEVEOIJRA DE CERVEJA & $\begin{array}{l}02 \text { cápsula } \\
08 \text { comprimido } \\
01 \text { po }\end{array}$ & $\begin{array}{l}B, L \\
A, B, G, G, G, G, H, H \\
B\end{array}$ & $\begin{array}{l}p, p \\
p, p, p, s, p, p, p, p \\
p\end{array}$ & $\begin{array}{l}-, c \\
-, \ldots, \ldots,-,- \\
-\end{array}$ & $\begin{array}{l}-, r c \\
r,-,,-,-,, \ldots \\
-\end{array}$ & $\begin{array}{l}8,- \\
A, B, \ldots, G, G,-,- \\
B\end{array}$ & $\begin{array}{l}-,- \\
-\end{array}$ & $\begin{array}{l}3,- \\
3,3, \ldots, \ldots, \ldots,- \\
5\end{array}$ & \\
\hline $\begin{array}{l}\text { ÓLEO DE GERME OF IRIGO } \\
\text { ZEDOÁRIA }\end{array}$ & $\begin{array}{l}06 \text { cápsula } \\
01 \text { cápsula }\end{array}$ & $\begin{array}{l}A, A, B, B, 0, D \\
F\end{array}$ & $p, p, p, p, p, b$ & $-, \cdots, \cdots,+, c$ & $r, r, \ldots, r, c$ & $\begin{array}{l}A, A, B, B, D,- \\
-\end{array}$ & $\cdots, \cdots, \cdots$ & $\begin{array}{l}3,3,3,5,2,- \\
1\end{array}$ & 0 \\
\hline
\end{tabular}

* Para o mesmo produtor com mais de um

lote amostrado, manteve-se a orrelaca sequencial entre estes e os dados discriminados na tabela.
- ausência de informação

a - bula como impresso avulso

b - "blister"

c - cartucho

- envelope de papel flastificado

fl- fibra-lata p - frasco plastico

$r$ - rótulo da embalagem primária $r^{*}$ - rótulo da embalagem secundária s - saco plástico

$\checkmark$ - frasco de vidro 
TABEL II - Aspecto legal dos produtos amostrados ( $n^{\circ}$ de lotes) quanto ao seu registro

\begin{tabular}{|c|c|c|c|c|c|c|c|c|c|c|}
\hline \multirow{2}{*}{ DROGA VEGEIAL } & \multirow{2}{*}{ AMOSIRAGTM } & \multirow{2}{*}{ PRODIJIOR* } & \multicolumn{4}{|c|}{ MINISIÉRIO DA SAÚDE } & \multirow{2}{*}{$\begin{array}{l}\text { MINISIÉRIO DA } \\
\text { AGRICULIURA }\end{array}$} & \multirow{2}{*}{ SEM REGISIRO } & \multirow{2}{*}{$\frac{\text { PROOUIO }}{\text { Alopático }}$} & \multirow{2}{*}{$\frac{\text { OF I C INAL }}{\text { Homeopático }}$} \\
\hline & & & Sem especificaçäo & DIMED & DINAL & 1 sento & & & & \\
\hline ALCACHORRA & $\begin{array}{l}05 \text { cápsula } \\
\text { Ol comprimido }\end{array}$ & $\begin{array}{l}B, B, L, 1, H) \\
k\end{array}$ & & & & k & & $L^{P}, L^{e}, N$ & & $B^{d}, B^{d}$ \\
\hline$B O L D O$ & $\begin{array}{l}02 \text { romprimito } \\
01 \text { pó }\end{array}$ & $L_{C}^{L}$ & & & & & & $L^{e}, L^{e}$ & $c^{a}$ & \\
\hline CARVĀO MEDICINAL & 01 comprimido & 1 & & & & I & & & $I^{a}$ & \\
\hline CASIANHA DA IMDIA & 02 cápsula & $B, B$ & & & & & & & & $B^{d}, B^{d}$ \\
\hline CAIUABA & 03 ć.jpsula & $B, B, M$ & & м & & & & & & $\theta^{d}, B^{d}$ \\
\hline CENITLHA ASIÓTICA & 03 cápsula & $B, B, 1$ & & & & & & $L^{e}$ & & $8^{d} \cdot B^{d}$ \\
\hline CONTRE I & 01 cápsula & B & & & & & & & & $8^{d}$ \\
\hline ESPINHEIRA SANTA & 01 cápsula & B & & & & & & & & $B^{d}$ \\
\hline [SP] RIIIINA & 03 cápsula & B., B,L & & & & & & $i^{e}$ & & $8^{d}, B^{d}$ \\
\hline rucus & 05 cáprula & $B, B, L, L, N$ & & & & & & $\mathrm{I}^{e}, \mathrm{~L}^{e}, \mathrm{H}$ & & $\theta_{d^{d}}^{d} \cdot \theta^{d}$ \\
\hline GINSEMT, GRASIIFIRO & $\begin{array}{l}02 \text { cápsula } \\
01 \text { comprimido }\end{array}$ & $L^{B, B}$ & $\iota$ & & & & & $L^{e}$ & & \\
\hline ginseng corrtano & 03 cápulata & $A, A, E$ & $A, A, E$ & & & & & & & \\
\hline gunaramá & $\begin{array}{l}06 \text { cápsula } \\
08 \text { comprimidn } \\
13 \text { pó }\end{array}$ & $\begin{array}{l}A, A, A, B, L, L, \\
C, C, G, G, H, K, K, N \\
B, B, C, C, O, H, H, J, J \\
P, R, S, 1\end{array}$ & $\begin{array}{l}A, A, A, \\
C, C \\
J^{2} \\
R, S\end{array}$ & $k, k$ & 1 & B & $\jmath^{\prime}$ & $\begin{array}{l}L^{e}, L^{e} \\
G, G, N \\
D\end{array}$ & $\begin{array}{l}k, k \\
c^{a}, c^{a} \\
p^{2}\end{array}$ & $\begin{array}{l}B^{d} \\
c^{d}, C^{d}, H^{d} \\
B^{d}, B^{d}, H^{d}, H^{d}\end{array}$ \\
\hline IECITINA DC SOJA & 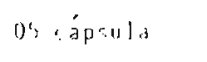 & $A, 18,8,1,0$ & $n, H, B$ & 0 & & & & $l^{e}$ & & \\
\hline LEVEDURA OE CFRVEJA & $\begin{array}{l}02 \text { capsula } \\
08 \text { comprimido } \\
01 \text { pó }\end{array}$ & $\begin{array}{l}B, L \\
A, B, G, G, G, G, H, H \\
B\end{array}$ & A & & & & & $\begin{array}{l}L^{\mathrm{e}} \\
\mathrm{G}, G, G, G, \mathrm{H}^{\mathrm{e}}, \mathrm{H}^{\mathrm{e}}\end{array}$ & $\mathrm{H} . \mathrm{H}$ & $\begin{array}{l}B^{2} \\
B^{2} \\
B^{2}\end{array}$ \\
\hline ÓLEO DE GERME DE TRIGO & 06 cápsula & $A, A, B, B, 0, D$ & $A, A, 0$ & & 0 & & & $B^{e}, B^{e}$ & & \\
\hline TIODÁRIA & Ol cáprula & $f$ & & & & $\mathrm{r}$ & & & ib & \\
\hline
\end{tabular}

* Para o mesmo produtor com mais de um lote amostrado, manteve-se a correlação sequencial entre estes e os dados discriminados na tabela. a - Farm. Bras.

b - Farm. Bras. I

c - Farm. Bras. II I d - Farmacopéia Honeopática Rrasileira e - Produto homeopático 
TABEIA III - Algumas informações relevantes inscritas no material gráfico dos produtos amostrados

\begin{tabular}{|c|c|c|c|c|c|c|c|c|c|c|c|}
\hline \multirow{2}{*}{ ORDGA VEGEIAL } & \multirow{2}{*}{ RHOSIRAGEM } & \multirow{2}{*}{ PRODUIOR* * } & \multirow{2}{*}{ ESIADO DA FEDERACÃO } & \multicolumn{2}{|c|}{ IOENTIFICAÇ,ĀO BOTÂNICA } & \multirow{2}{*}{$\begin{array}{l}\text { PRODUIO } \\
\text { NATURAL }\end{array}$} & \multirow{2}{*}{$\begin{array}{l}\text { AF IRMAÇAO DE } \\
\text { INOCUIDADE }\end{array}$} & \multirow{2}{*}{$\begin{array}{l}\text { ALIMENTO/ } \\
\text { PRODUTO } \\
\text { DIETÉTICO }\end{array}$} & \multirow{2}{*}{$\begin{array}{l}\text { COMPLEKENTO } \\
\text { NUTRITIYO }\end{array}$} & \multirow{2}{*}{$\begin{array}{l}\text { MILIGRAMAS } \\
\text { DA DROGA } \\
\text { POR UHIOADE }\end{array}$} & \multirow{2}{*}{ POSOLOGIA } \\
\hline & & & & Presença & Nome científico & & & & & & \\
\hline ALCACHOFRA & $\begin{array}{l}05 \text { cápsula } \\
01 \text { comprimido }\end{array}$ & $\begin{array}{l}B, B, L, L, N \\
K\end{array}$ & $\begin{array}{l}\text { SP }(B, L, N) \\
\text { RJ }\end{array}$ & 1,1 & Cymara scolymus & & & & & $\begin{array}{l}\mathrm{L}, \mathrm{L} \\
\mathrm{K}\end{array}$ & $\mathrm{L}, \mathrm{L}$ \\
\hline BOLDO & $\begin{array}{l}02 \text { comprimido } \\
01 \text { comprimido }\end{array}$ & $\begin{array}{l}L, L \\
C\end{array}$ & $\begin{array}{l}S P(L) \\
S P\end{array}$ & $\begin{array}{l}\mathrm{L} \\
\mathrm{C}\end{array}$ & $\begin{array}{l}\text { Peunus boldus } \\
\text { pFumus bolous }\end{array}$ & c & c & & & & $\begin{array}{l}l, L \\
C\end{array}$ \\
\hline CARУÃO MEDICINAL & al comprimido & 1 & $S P$ & & & 1 & I & & & I & 1 \\
\hline CASTANHA DA INDIA & 02 ćasula & 8.8 & $S P(B)$ & & & & & & & & \\
\hline CAIUABa & 03 cápsula & $B, B, M$ & $S P(B, M)$ & & & m & & & & & M \\
\hline CENTELHA ASIÁHICA & 03 ápsula & $8,8,1$ & $S P(B, L)$ & $B, B$ & CENTELLA AS. & & & $\mathrm{L}$ & & & l \\
\hline CONTRE I & 01 cápsula & 8 & SP & & & & & & & & \\
\hline ESPINHEIRA SANIA & 01 capsula & B & $S P$ & & & & & & & & \\
\hline CSPIRULINA & 03 cápsula & B. B. L & $S P(B L)$ & & & & & 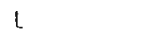 & & L & L \\
\hline rucus & 05 cápsula & $0.8 .1 .1 . \mathrm{N}$ & $\operatorname{SP}(B, L, N)$ & $B, B, L, L, N$ & $1 *(B, B), 2^{*}(L, L), 3^{*}(\mathrm{~N})$ & & & & & $\mathrm{L}, \mathrm{L}$ & $L, L$ \\
\hline GINSENG BRASILEIRO & $\begin{array}{l}02 \text { cápsula } \\
01 \text { comprimido }\end{array}$ & $\begin{array}{l}B, B \\
1\end{array}$ & $\begin{array}{l}S P(B) \\
S P\end{array}$ & $L$ & Pfaffia paniculata & & & & & & \\
\hline GINSENG COREANO & 03 cápsula & $A, A, E$ & $S P(A), R S(C)$ & & & E & $\varepsilon$ & & & $B, B, L$ & $A, A, E$ \\
\hline GULARANá & $\begin{array}{l}06 \text { cápsula } \\
08 \text { comprimido } \\
13 \text { pó }\end{array}$ & $\begin{array}{l}A, A, A, B, L, L \\
C, C, G, G, H, K, K, H \\
B, B, C, C, D, H, H, J \\
J, P, R, S, I\end{array}$ & $\begin{array}{l}\operatorname{SP}(A, B, L) \\
\operatorname{SP}(C, G, H, N), R J(K) \\
\operatorname{SP}(B, C, H), P A(O), H I(J), \\
M I(J), S P(P, R, S, I)\end{array}$ & $\begin{array}{l}L_{1}^{\prime} \\
C, C \\
C, C \\
j, \\
\end{array}$ & $\begin{array}{l}\text { Paulinia sorbilis }(1) \\
\text { PaUlinia Cupana }(C, C) \\
\text { PaUlinea Cupana }(C, C) \\
4^{*}(J, 1)\end{array}$ & $\begin{array}{l}A, A, \cap \\
C, C, D, H, H, J \\
J, P, R, T\end{array}$ & $\begin{array}{l}A, A, A \\
C, C \\
P\end{array}$ & & & $\begin{array}{l}A, A, A \\
N, G, G\end{array}$ & $\begin{array}{l}A, A, A, L, C \\
K, K \\
C, C, D, J \\
J, P, R, S, T\end{array}$ \\
\hline LECIIINA DE SOJA & 05 cápsula & $A, B, B, L, 0$ & $S P(A, B, C, D)$ & & & $A, D$ & A & $A, L, D$ & A & $A, B, B, L, O$ & $A, L, Q$ \\
\hline LTVLOURA DE CERVE JA & $\begin{array}{l}02 \text { cápsula } \\
08 \text { comprimido } \\
01 \text { pó }\end{array}$ & $\begin{array}{l}B, L \\
A, B, G, G, C, C, H, H \\
B\end{array}$ & $\begin{array}{l}S P(B, L) \\
S P(A, B, C, H) \\
S P\end{array}$ & & & $\begin{array}{l}\text { L } \\
\text { A }\end{array}$ & A & & & $A, G, G, G, G$ & L \\
\hline óleO de GERME DE IRIGO & 06 rápsula & $A, A, B, B, 0,0$ & $S P(A, B, 0), S C(0)$ & & & $A, A, 0,0$ & $A, A, O$ & $A, A, B$ & $A, A$ & $A, A, B, B, 0, D$ & $n, A, 0.0$ \\
\hline ZEDOÁRIA & 01 rásula & 1 & $S^{p}$ & $r$ & Curcuma zedoaria & & & & & $r$ & $F$ \\
\hline
\end{tabular}

* Para o mesmo produtor com mais de um lote amostrado, manteve-se a correlaça sequencial entre estes e os dados discriminados rá tabela.

$1 *$ - FUCUS VES

$2^{*}$ - Fucus vesiculosus

$3^{*}$ - FUCUS VESICULOSUS 
TABELA IV - Frequência de distribuição da carga bacteriana aeróbia mesófila (NMP/g) nos produtos amostrados segundo a espécie vegetal

\begin{tabular}{|c|c|c|c|c|c|c|c|c|c|c|c|}
\hline \multirow{2}{*}{ OROGA VEGETAL } & \multirow{2}{*}{ NOAMOSTRA } & \multicolumn{10}{|c|}{ BACTÉRIAS/g } \\
\hline & & $<10$ & $10-10^{2}$ & $10^{2}-10^{3}$ & $10^{3}-10^{4}$ & $10^{4}-10^{5}$ & $10^{5}-10^{6}$ & $10^{6}-10^{7}$ & $10^{7}-10^{8}$ & $10^{8}-10^{9}$ & $10^{9}-10^{1.0}$ \\
\hline ALCACHOFRA & 6 & - & - & - & 3 & 2 & 1 & - & - & - & - \\
\hline BOLDO & 3 & - & - & - & - & 2 & 1 & - & - & - & - \\
\hline CARVÃO MEDICINAL & 1 & - & - & - & 1 & - & - & - & - & - & - \\
\hline CASTANHA DA INDIA & 2 & - & - & 1 & 1 & - & - & - & - & - & - \\
\hline CATUABA & 3 & - & - & - & 2 & 1 & - & - & - & - & - \\
\hline CERTELha asiática & 3 & - & - & - & - & - & 2 & - & - & - & 1 \\
\hline CONFREI & 1 & - & - & 1 & m & - & - & - & - & - & - \\
\hline ESPINHEIRA SANTA & 1 & - & - & - & - & - & - & 1 & - & - & - \\
\hline ESPIRULINA & 3 & - & - & - & - & 1 & - & 1 & - & 1 & - \\
\hline Fucus & 5 & - & - & 1 & 1 & 1 & 2 & - & - & - & - \\
\hline GINSENG BRASILEIRO & . & - & - & - & - & - & 1 & 1 & 1 & - & - \\
\hline GI MSENG COREANO & 3 & - & 1 & 1 & - & 1 & - & - & - & - & - \\
\hline GUIARAMÁ & 27 & 1 & - & 1 & 2 & 9 & 8 & 5 & 1 & - & - \\
\hline LECITIMA DE SOJA & 5 & - & - & $t^{i}$ & 1 & - & - & - & - & - & - \\
\hline LEVEDURA DE CERVEJA & 11 & 1 & 4 & 2 & 3 & 1 & - & - & - & - & - \\
\hline OLEO DE GERME DE TRIGO & 6 & 4 & 1 & 1 & - & - & - & - & - & - & - \\
\hline ZEDOÁRIA & 1 & - & - & 1 & - & - & - & - & - & - & - \\
\hline $101 A L$ & 84 & 6 & 6 & 13 & 14 & 18 & 15 & 8 & 2 & 1 & 1 \\
\hline
\end{tabular}


$\mathbb{T} \mathbb{A} E \mathbb{W}$ - Frequência de distribuição da carga de esporos de bactérias aeróbias mesófilas (NMP/g) nos produtos amostrados segundo a espécie vegetal

\begin{tabular}{|c|c|c|c|c|c|c|c|c|c|}
\hline \multirow{2}{*}{ DROGA VEGETAL } & \multirow{2}{*}{ NO AMUSTRA } & \multicolumn{8}{|c|}{ ESPOROS BACTERIANOS/g } \\
\hline & & $<10$ & $10-10^{2}$ & $10^{2}-10^{3}$ & $10^{3}-10^{4}$ & $10^{4}-10^{5}$ & $10^{5}-10^{6}$ & $10^{6}-10^{7}$ & $10^{7}-10^{8}$ \\
\hline ALCACHOFRA & 6 & - & 1 & 2 & - & 2 & 1 & - & - \\
\hline $80 L 00$ & 3 & - & - & 1 & 1 & 1 & - & - & - \\
\hline CARYÄO MEDICINAL & 1 & - & - & 1 & - & - & - & - & - \\
\hline CASTANHA DA INDIA & 2 & - & - & 1 & 1 & - & - & - & - \\
\hline CATUABA & 3 & - & - & 1 & $!$ & 1 & - & - & - \\
\hline CENTELHA ASIÁTICA & 3 & - & - & - & 1 & 1 & - & - & 1 \\
\hline COMFREI & 1 & - & 1 & - & - & - & - & - & - \\
\hline ESPINHEIRA SAMTA & 1 & - & - & - & - & - & 1 & - & - \\
\hline ESPIRULINA & 3 & - & - & - & 1 & 1 & 1 & $=$ & - \\
\hline FUCUS & 5 & & - & 1 & 2 & 2 & - & - & - \\
\hline GINSENG GRASILEIRO & 3 & - & - & - & 1 & - & 1 & 1 & - \\
\hline GINSENG COREANO & 3 & - & 1 & 1 & - & 1 & - & - & - \\
\hline GUARAMá & 27 & 1 & - & 2 & 2 & 6 & 11 & 5 & - \\
\hline LECITINA OE SOJA & 5 & - & - & 3 & 1 & - & 1 & - & - \\
\hline LEVEOURA OE CERVESA & 11 & 2 & 4 & 4 & 1 & - & - & - & - \\
\hline ÓLEO DE GERME DE TRIGO & 6 & 2 & 3 & - & 1 & - & - & - & - \\
\hline ZEDOÁRIA & 1 & $i$ & - & - & - & - & - & - & - \\
\hline TOIAL & 84 & 6 & 10 & 17 & 13 & 15 & 16 & 5 & 1 \\
\hline
\end{tabular}


TABEILAII - Frequência de distribuição da carga fúngica (NMP/g) nos produtos amostrados segundo a espécie vegetal

\begin{tabular}{|c|c|c|c|c|c|c|c|}
\hline \multirow[b]{2}{*}{ OROGA VEGETAL } & \multirow[b]{2}{*}{ NO AMOSTRA } & \multicolumn{5}{|c|}{ FUNGOS $/ g$} & \multirow[b]{2}{*}{$10^{5}-10^{6}$} \\
\hline & & $<10$ & $10-10^{2}$ & $10^{2}-10^{3}$ & $10^{3}-10^{4}$ & $10^{4}-10^{5}$ & \\
\hline ALCACHOFRA & $\delta$ & 4 & - & 2 & - & - & - \\
\hline BOLDO & 3 & 2 & 1 & - & - & - & - \\
\hline CARVĀO MEDICINAL & 1 & 1 & - & - & - & - & - \\
\hline CASTANHA DA INOIA & 2 & 1 & 1 & - & - & - & - \\
\hline CATUABA & 3 & - & 2 & - & 1 & - & - \\
\hline CENTELHA ASIÁTICA & 3 & - & - & - & 1 & 2 & - \\
\hline CONFREI & 1 & 1 & - & - & - & - & - \\
\hline ESPINHEIRA SANTA & 1 & 1 & - & - & - & - & - \\
\hline ESPIRULINA & 3 & 3 & - & - & - & - & - \\
\hline FUCUS & 5 & 1 & - & 1 & 2 & 1 & - \\
\hline GINSENG BRASILEIRO & 3 & 2 & - & - & - & 1 & - \\
\hline GIMSENG COREANO & 3 & - & 2 & 1 & - & - & - \\
\hline GUARANÁ & 27 & 5 & 7 & 2 & 6 & 5 & 2 \\
\hline LECITINA DE SOJA & 5 & 4 & 1 & - & - & - & - \\
\hline LEVEDURA DE CERVEJA & 11 & 9 & - & 2 & - & - & - \\
\hline ÓLEO DE GERME DE TRIGO & 6 & $\hat{0}$ & - & - & - & - & - \\
\hline ZEDOÁRIA & 1 & 1 & - & - & - & - & - \\
\hline TOCI A L & 84 & 41 & 14 & 8 & 10 & 9 & 2 \\
\hline
\end{tabular}


TABEILA VII - Isolamento de patogênicos específicos dos produtos amostrados segundo a espécie vegetal

\begin{tabular}{|c|c|c|c|c|c|c|}
\hline \multirow{2}{*}{ OROGA VEGETAL } & \multirow{2}{*}{ AMOSTRA } & \multicolumn{3}{|c|}{ COLIFORMES } & \multirow{2}{*}{$\underline{\text { E. coli }}$} & \multirow{2}{*}{ Salmonella sp. } \\
\hline & & PRESUNTIVA & TOTAIS/CONFIRMATÓRIA & FECAIS & & \\
\hline Alcachofra & 6 & 4 & 2 & - & - & - \\
\hline $801 d 0$ & 3 & 3 & 2 & - & - & - \\
\hline Carvào medicinal & 1 & 1 & 1 & - & - & - \\
\hline Castanha de India & 2 & 1 & 1 & - & - & - \\
\hline Catuaba & 3 & 3 & 1 & - & - & - \\
\hline Centelha asiática & 3 & 3 & 3 & 1 & 1 & 1 \\
\hline Confrei & 1 & 1 & - & - & - & - \\
\hline Espinheira santa & 1 & 1 & - & - & - & - \\
\hline Espirulira & 3 & 3 & 3 & 1 & 1 & 1 \\
\hline Fucus & 5 & 5 & 5 & - & - & - \\
\hline Ginseng brasileiro & 3 & 3 & 2 & 2 & 1 & 1 \\
\hline Ginseng coreano & 3 & 3 & 1 & 1 & - & - \\
\hline Guaraná & 27 & 22 & 14 & 7 & 1 & 1 \\
\hline Lecitina de soja & 5 & - & - & - & - & - \\
\hline Levedura de cerveja & 11 & 8 & 5 & 1 & 1 & 1 \\
\hline óleo de germe de trigo & 6 & - & - & - & - & - \\
\hline Zedoária & 1 & - & - & - & - & - \\
\hline IOSTA & 84 & 61 & 40 & 13 & 5 & 5 \\
\hline
\end{tabular}


TABEA VIII - Frequência de distribuição da carga bacteriana aeróbia mesófila (NMP/g) nos produtos amostrados segundo a for ma farmacêutica

\begin{tabular}{|c|c|c|c|c|c|c|c|}
\hline & \multirow{2}{*}{ NMP $/ g$} & \multicolumn{2}{|c|}{ CÁPSULA } & \multicolumn{2}{|c|}{ COMPRIMIDO } & \multicolumn{2}{|c|}{ pó } \\
\hline & & $N \underline{0}$ & $\%$ & $N \cong$ & $\%$ & $N D$ & $\%$ \\
\hline & $<10$ & 4 & 8,3 & 2 & 9,5 & - & - \\
\hline 10 & $-10^{2}$ & 2 & 4,2 & 4 & 19,0 & - & - \\
\hline $10^{2}$ & $-10^{3}$ & 10 & $20, B$ & 3 & 14,3 & - & - \\
\hline $10^{3}$ & $-10^{4}$ & 9 & 18,8 & 2 & 9,5 & 3 & 20,0 \\
\hline $10^{4}$ & $-10^{5}$ & 9 & 18,8 & 5 & 23.8 & 4 & 26.7 \\
\hline $10^{5}$ & $-10^{6}$ & 7 & 14,6 & 3 & 14,3 & 5 & 33,3 \\
\hline $10^{6}$ & $-10^{7}$ & 4 & 8.3 & 1 & 4,8 & 3 & 20,0 \\
\hline $10^{7}$ & $-10^{8}$ & 1 & 2,1 & 1 & 4,8 & - & - \\
\hline $10^{8}$ & $-10^{9}$ & i & 2,1 & - & - & - & - \\
\hline $10^{9}$ & $-10^{10}$ & 1 & 2,1 & - & - & - & - \\
\hline 10 & I A L & 48 & & 21 & & 15 & \\
\hline
\end{tabular}

$\mathbb{T} \mathbb{A} \mathbb{B} \mathbb{A} \mathbb{A} \mathbb{X}$ - Frequência de distribuição da carga de esporos de bactérias aeróbias mesófilas (NMP/g) nos produtos amostrados segundo a forma farmacêutica

\begin{tabular}{|c|c|c|c|c|c|c|}
\hline \multirow{2}{*}{$N M P / g$} & \multicolumn{2}{|c|}{ CÁPSULA } & \multicolumn{2}{|c|}{ COMPRIMIDO } & \multicolumn{2}{|c|}{ Pó } \\
\hline & $N Q$ & $\%$ & No & $\%$ & No & $\%$ \\
\hline$<10$ & 3 & 6,2 & 3 & 14,3 & - & - \\
\hline $10-10^{2}$ & 6 & 12,5 & 3 & 14,3 & 1 & 6,7 \\
\hline $10^{2}-10^{3}$ & 10 & 20,8 & 4 & 19,0 & 3 & 20,0 \\
\hline $10^{3}-10^{4}$ & 9 & 18,8 & 3 & 14.3 & 1 & 6.7 \\
\hline $10^{4}-10^{5}$ & 7 & 14,6 & 4 & 19,0 & 4 & 26.7 \\
\hline $10^{5}-10^{6}$ & 8 & 16.7 & 4 & 19,0 & 4 & 26,7 \\
\hline $10^{6}-10^{7}$ & 4 & 8,3 & - & - & 2 & 13,3 \\
\hline $10^{7}-10^{8}$ & 1 & 2,1 & - & - & - & - \\
\hline $\begin{array}{lllll}T & 0 & T & A & L\end{array}$ & 48 & & 21 & & 15 & \\
\hline
\end{tabular}


TABELA X - Frequência de distribuição da carga fúngica (NMP/g) nos produtos amostrados segundo a forma farmacêutica

\begin{tabular}{|c|c|c|c|c|c|c|c|}
\hline & \multirow{2}{*}{$N M P / g$} & \multicolumn{2}{|c|}{ CÁPSULA } & \multicolumn{2}{|c|}{ COMPRIMIDO } & \multicolumn{2}{|c|}{ Pó } \\
\hline & & $N Q$ & $\%$ & $N \underline{0}$ & $\%$ & $N \cong$ & $\%$ \\
\hline & $<10$ & 24 & 50.0 & 17 & 80,9 & - & - \\
\hline 10 & $-10^{2}$ & 7 & 14.6 & 2 & 9,5 & 5 & 33,3 \\
\hline $10^{2}$ & $-10^{3}$ & 5 & 10,4 & 1 & 4.8 & 2 & 13,3 \\
\hline $10^{3}$ & $-10^{4}$ & G & 12,5 & 1 & 4.8 & 3 & 20,0 \\
\hline $10^{4}$ & $-10^{5}$ & 5 & 10,4 & - & - & 4 & 26,7 \\
\hline $10^{5}$ & $-10^{6}$ & 1 & 2,1 & - & - & 1 & 6,7 \\
\hline $\begin{array}{ll}\mathrm{T} & 0\end{array}$ & $T A L$ & 48 & & 21 & & 15 & \\
\hline
\end{tabular}




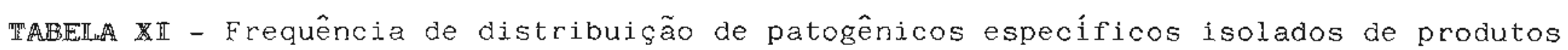
amostrados segundo a forma farmacêutice

\begin{tabular}{|c|c|c|c|c|c|c|c|c|c|c|c|}
\hline \multirow{3}{*}{ FORMA FARHACÊUTICA } & \multirow{3}{*}{$\begin{array}{c}N Q \\
\text { AMOSIRA }\end{array}$} & \multicolumn{6}{|c|}{ COLIFORMES } & \multirow{2}{*}{\multicolumn{2}{|c|}{ E. coli }} & \multirow{2}{*}{\multicolumn{2}{|c|}{$\begin{array}{c}\text { Salmonella sp } \\
\text { (susperta) }\end{array}$}} \\
\hline & & \multicolumn{2}{|c|}{ PRESURTIYA } & \multicolumn{2}{|c|}{ TOTAIS/CONF IRHATÚRIA } & \multicolumn{2}{|c|}{ FECAIS } & & & & \\
\hline & & NQ & $\%$ & № & $\%$ & NO & $\%$ & № & $\%$ & № & $\%$ \\
\hline CÁPSULA & 48 & 31 & 64,6 & 23 & 47,9 & 7 & 14,6 & 3 & 6,3 & 3 & 6,3 \\
\hline COMPRIMIOO & 21 & 15 & 71,4 & 7 & 33,3 & I & 4.8 & - & - & - & - \\
\hline Pó & 15 & 15 & 100,0 & 10 & 66,7 & 5 & 33,3 & 2 & 13,3 & 2 & 13,3 \\
\hline YOIAL & 84 & 61 & 72,6 & 40 & 47,6 & 13 & 15,5 & 5 & 6.0 & 5 & 6,0 \\
\hline
\end{tabular}


TABELA XII - Frequência de distribuição de bolor, levedura e de ambos nos produtos amostrados segundo a forma farma cêutica

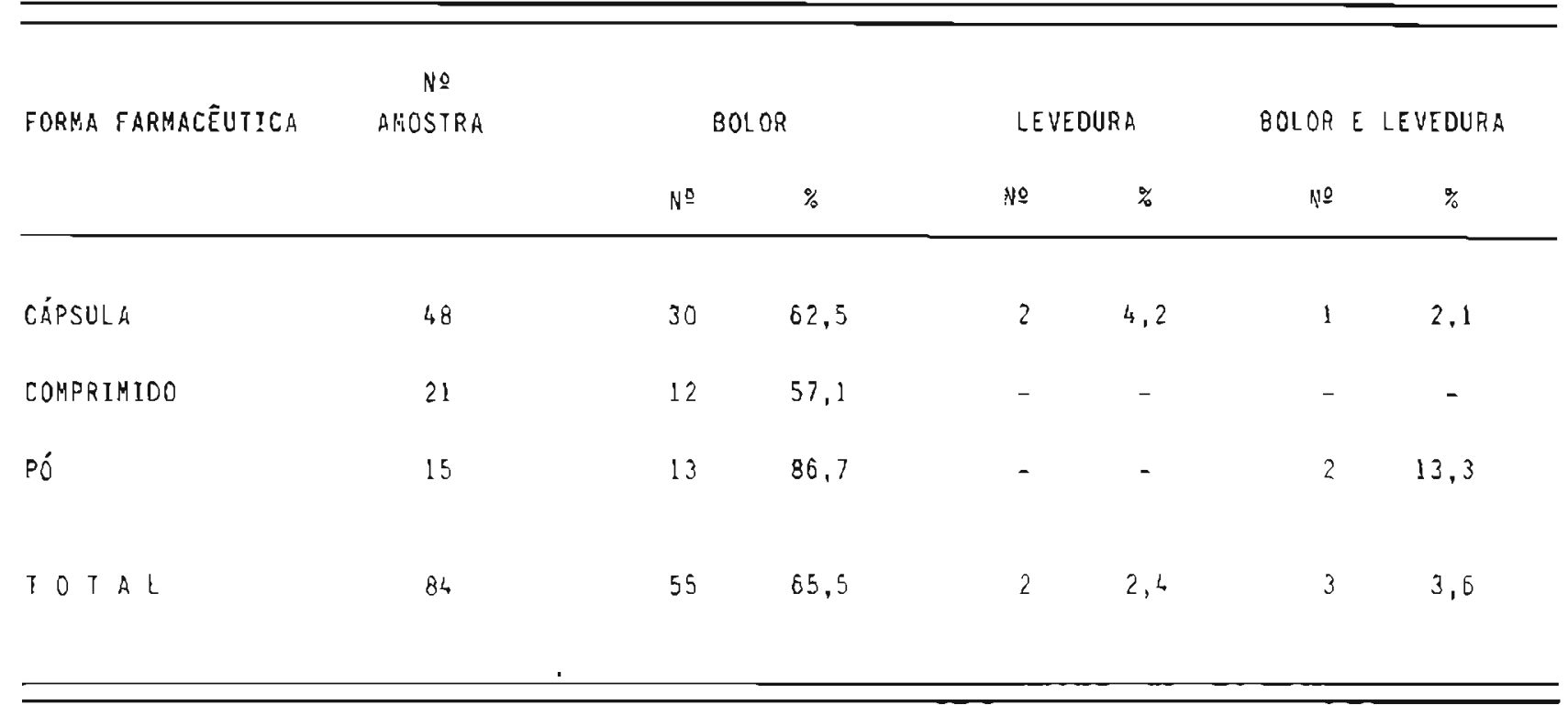


TABEIA XIII - Relação entre carga bacteriana aeróbia mesófila e incidência de coliformes totais, coliformes fecais $e$ Salmonella sp.

\begin{tabular}{|c|c|c|c|c|c|c|c|c|c|c|}
\hline \multirow{3}{*}{$N M P / 9$} & \multicolumn{6}{|c|}{ COLIFORMES } & \multirow{2}{*}{\multicolumn{2}{|c|}{$\underline{\text { E. coli }}$}} & \multirow{2}{*}{\multicolumn{2}{|c|}{$\frac{\text { Salmonella sp. }}{\text { (suspeita) }}$}} \\
\hline & \multicolumn{2}{|c|}{ PRESUNTIVA } & \multicolumn{2}{|c|}{ TOTAIS/CONFIRMATÓRIA } & \multicolumn{2}{|c|}{ FECAIS } & & & & \\
\hline & № & $\%$ & № & $\%$ & Nㅗ은 & $\%$ & $n^{2}$ & $\%$ & $\mathrm{~N}^{2}$ & $\%$ \\
\hline$<10$ & 1 & 1,2 & - & - & - & - & - & - & - & - \\
\hline $10-10^{2}$ & 3 & 3,6 & - & - & - & - & - & - & - & - \\
\hline $10^{2}-10^{3}$ & $s$ & 6,0 & 3 & 3.6 & - & - & - & - & - & - \\
\hline $10^{3}-10^{4}$ & 11 & 13,1 & 7 & 8,3 & 1 & 1,2 & 1 & 1,2 & 1 & 1,2 \\
\hline $10^{4}-10^{5}$ & 15 & 17,9 & 9 & 10,7 & 2 & 2,4 & - & - & - & - \\
\hline $10^{5}-10^{5}$ & 15 & 17,9 & 11 & 13,1 & 3 & 3,6 & 1 & 1,2 & 1 & 1,2 \\
\hline $10^{5}-10^{7}$ & 7 & 8,3 & 6 & 7,1 & 3 & 3,6 & 1 & 1.2 & 1 & 1,2 \\
\hline $10^{7}-10^{8}$ & 2 & 2,4 & 2 & 2,4 & 2 & 2,4 & - & - & - & - \\
\hline $10^{8}-10^{9}$ & 1 & 1.2 & 1 & 1,2 & 1 & 1,2 & 1 & 1,2 & 1 & 1.2 \\
\hline $10^{9}-10^{10}$ & $!$ & 1,2 & 1 & 1,2 & 1 & 1,2 & 1 & 1,2 & 1 & 1,2 \\
\hline TOS A L & 51 & 72,7 & 40 & 47.6 & 13 & 15,5 & $s$ & 6,0 & 5 & 6,0 \\
\hline
\end{tabular}


TABELA XIV - Relação entre carga de esporos bacterianos aeróbios mesófilos e incidência de coliformes totais, coli formes fecais e Salmonella sp.

\begin{tabular}{|c|c|c|c|c|c|c|c|c|c|c|}
\hline \multirow{3}{*}{$N M P / g$} & \multicolumn{6}{|c|}{$C O L I F O R M E S$} & \multirow{2}{*}{\multicolumn{2}{|c|}{ E. coli }} & \multirow{2}{*}{\multicolumn{2}{|c|}{$\frac{\text { Salmonella }}{\text { (suspeita) }}$}} \\
\hline & \multicolumn{2}{|c|}{ PRESUNTIVA } & \multicolumn{2}{|c|}{ TOIAIS/CONFIRMATÓRIA } & \multicolumn{2}{|c|}{ FECAIS } & & & & \\
\hline & NQ & $\%$ & Na & $\%$ & $N^{0}$ & $\%$ & $\mathrm{~N}^{0}$ & $\%$ & $N^{2}$ & $\%$ \\
\hline$<10$ & 1 & 1.2 & - & - & - & - & - & - & - & - \\
\hline $10-10^{2}$ & 7 & 8,3 & 3 & 3.6 & 1 & 1,2 & 1 & 1,2 & 1 & 1,2 \\
\hline $10^{2}-10^{3}$ & 10 & 11.9 & 5 & 6,0 & - & - & - & - & - & - \\
\hline $10^{3}-10^{4}$ & 10 & 11,9 & 9 & 10.7 & 1 & 1,2 & - & - & - & - \\
\hline $10^{4}-10^{5}$ & 13 & 15,5 & 8 & 9,5 & 3 & 3.6 & 2 & 2,4 & $?$ & 2,4 \\
\hline $10^{5}-10^{6}$ & 14 & 16,7 & 9 & 10,7 & 4 & 4,8 & - & - & - & - \\
\hline $10^{6}-10^{7}$ & 5 & 6,0 & 5 & 6,0 & 4 & 4,8 & 2 & 2,4 & 2 & 2,4 \\
\hline $10^{7}-10^{8}$ & 1 & 1.2 & 1 & 1,2 & - & - & - & - & - & - \\
\hline$T O T A L$ & 61 & 72.6 & 40 & 47,6 & 13 & 15,5 & 5 & 6.0 & 5 & 6,0 \\
\hline
\end{tabular}


TABELA XV - Relação entre carga de fungos e inciaência de coliformes totais, coliformes fecais e Salmonella sp.

\begin{tabular}{|c|c|c|c|c|c|c|c|c|c|c|}
\hline \multirow{3}{*}{$N M P / 9$} & \multicolumn{6}{|c|}{ COLIFORMES } & \multirow{2}{*}{\multicolumn{2}{|c|}{ E. $\operatorname{coli}$}} & \multirow{2}{*}{\multicolumn{2}{|c|}{ Salmonella sp. }} \\
\hline & \multicolumn{2}{|c|}{ PRESUNTIVA } & \multicolumn{2}{|c|}{ TOTAIS/CONFIRMATÓRIA } & \multicolumn{2}{|c|}{ recaIS } & & & & \\
\hline & N2 & $\%$ & № & $\%$ & № & $\%$ & № & $\%$ & № & $\%$ \\
\hline$<10$ & 23 & 27,4 & 13 & 15,5 & 2 & 2,4 & 1 & 1,2 & 1 & 1,2 \\
\hline $10-10^{2}$ & 12 & 14,3 & 4 & 4,8 & 1 & 1,2 & - & - & - & - \\
\hline $10^{2}-10^{3}$ & 7 & 8,3 & 5 & 6,0 & 2 & 2,4 & 1 & 1,2 & 1 & 1.2 \\
\hline $10^{3}-10^{4}$ & 9 & 10,7 & 9 & 10,7 & 4 & 4,8 & - & - & - & - \\
\hline $10^{4}-10^{5}$ & 8 & 9.5 & 7 & 8.3 & 3 & 3,6 & 3 & 3,6 & 3 & 3.6 \\
\hline $10^{5}-10^{6}$ & 2 & 2,4 & 2 & 2,4 & 1 & 1,2 & - & - & - & - \\
\hline $\begin{array}{llll}I O & T & A & L\end{array}$ & 61 & 72,6 & 40 & 47,6 & 13 & 15,6 & 5 & 6,0 & 5 & 5,0 \\
\hline
\end{tabular}


TMBERA XVII - Carga de microorganismos viáveis (NMP/g) e estimativa de Escherichia coli nos 13 lotes positivos para coliformes fecais

\begin{tabular}{|c|c|c|c|c|c|c|}
\hline DROGA VEGETAA & FORAB FARMACÊUTICA & PRODUTOR & $\begin{array}{c}\text { BACTÉRIAS } \\
\text { AERÓBIAS } \\
\text { MESÓF ILAS } \\
\text { NMF } / g\end{array}$ & $\begin{array}{c}\text { ESPOROS } \\
\text { BAC TERIANOS } \\
\text { NMP } / \mathrm{g}\end{array}$ & $\begin{array}{l}\text { FUMGOS } \\
\text { MMP } / 9\end{array}$ & $\frac{\text { E. coli }}{\mathrm{NHP} / \mathrm{g}}$ \\
\hline CENIELHA ASIÁTICA & cápsula & $B$ & $5,1 \times 10^{9}$ & $2,6 \times 10^{4}$ & $1,7 \times 10^{4}(b)$ & $1,5 \times 10^{2}$ \\
\hline ESPIRULL INA & cápsula & B & $4,7 \times 10^{8}$ & $3,3 \times 10^{4}$ & $2,0 \times 10^{4}(b)$ & $9,3 \times 10$ \\
\hline \multirow[t]{2}{*}{ GINSENG BRASILEIRO } & cápsula & 8 & $1,0 \times 10^{6}$ & $1.7 \times 10^{6}$ & $1,2 \times 10^{4}(b)$ & $4,3 \times 10$ \\
\hline & & L & $9,3 \times 10^{7}$ & $4,3 \times 10^{3}$ & $<3,0$ & - \\
\hline GIHSENG COREANO & cápsula & E & $7,8 \times 10^{4}$ & $2,6 \times 10^{4}$ & $\begin{array}{l}4,3 \times 10(b) \\
1,5 \times 10^{2}(1)\end{array}$ & - \\
\hline \multirow[t]{7}{*}{ GUARamá } & cápsula & A & $2,3 \times 10^{5}$ & $1,5 \times 10^{6}$ & $4.6 \times 10^{5}(b)$ & - \\
\hline & & B & $2,5 \times 10^{4}$ & $9,3 \times 10^{5}$ & $2,6 \times 10^{3}(b)$ & - \\
\hline & & $L$ & $2,7 \times 10^{7}$ & $3,3 \times 10^{6}$ & $2,5 \times 10^{3}(b)$ & - \\
\hline & pó & B & $4,6 \times 10^{6}$ & $9,3 \times 10^{5}$ & $9,3 \times 10^{3}(\mathrm{~b})$ & - \\
\hline & & $B$ & $2,4 \times 10^{5}$ & $2,4 \times 10^{6}$ & $1,1 \times 10^{4}(b)$ & $2,3 \times 10$ \\
\hline & & c & $6,4 \times 10^{5}$ & $2,4 \times 10^{5}$ & $4,3 \times 10^{3}(b)$ & - \\
\hline & & $H$ & $2.4 \times 10^{6}$ & $4,3 \times 10^{5}$ & $7,5 \times 10^{2}(b)$ & - \\
\hline \multirow[t]{2}{*}{ LEYEDURA DE CERVEJA } & pó & 8 & $2,3 \times 10^{3}$ & $3,9 \times 10$ & $1,5 \times 10^{2}(b)$ & 4,0 \\
\hline & & & & & $7,5 \times 10(1)$ & \\
\hline
\end{tabular}


IABELA XVII - Carga de microorganismos viáveis (NMP/g) das amostras do produtor A

\begin{tabular}{|c|c|c|c|c|}
\hline \multirow[t]{2}{*}{ OROGA VEGETAL } & \multirow[t]{2}{*}{ FORMA FARMACẼUTICA } & \multirow{2}{*}{$\begin{array}{c}\text { BACTÉRIAS AERÓBIAS } \\
\text { MESÓFILAS } \\
\text { NMP/g }\end{array}$} & \multirow{2}{*}{$\begin{array}{c}\text { ESPOROS } \\
\text { BACTERIANOS } \\
\text { NMP } / g\end{array}$} & \multirow{2}{*}{$\begin{array}{l}\text { FUNGOS } \\
\text { NMP } / 9\end{array}$} \\
\hline & & & & \\
\hline \multirow[t]{2}{*}{ GINSENG COREANO } & cápsula & $2,5 \times 10$ & $4.7 \times 10$ & $1,0 \times 10(b)$ \\
\hline & & $1,0 \times 10^{2}$ & $1,0 \times 10^{2}$ & $1,0 \times 10(b)$ \\
\hline \multirow[t]{3}{*}{ GUARANÁ } & cápsula & $2,5 \times 10^{4}$ & $2,5 \times 10^{5}$ & $2,5 \times 10(b)$ \\
\hline & & $4,7 \times 10^{4}$ & $2,3 \times 10^{5}$ & $2,5 \times 10^{2}(b)$ \\
\hline & & $2,3 \times 10^{5}$ & $1,5 \times 10^{6}$ & $4,6 \times 10^{5}(b)$ \\
\hline LECITINA DE SOJA & cápsula & $2,5 \times 10^{2}$ & $2,3 \times 10^{2}$ & $9,0\{1\}$ \\
\hline LEVEDURA DE CERVEJA & comprimido & $2,3 \times 10$ & $2,3 \times 10^{2}$ & $9,0(b)$ \\
\hline \multirow[t]{2}{*}{ ÓLEO DE GERME DE TRIGO } & cápsula & $2,5 \times 10$ & $<3,3$ & $<3,3(b)$ \\
\hline & & 4.0 & $1,5 \times 10^{3}$ & $<3,0(b)$ \\
\hline
\end{tabular}


IIABIIA XVII - Carga de microorganismos viáveis (NMP/g) das amostras do produtor $B$

\begin{tabular}{|c|c|c|c|c|}
\hline DROGA VEGETAL & FORMA FARMACẼUIICA & $\begin{array}{c}\text { BACTÉRIAS AERÓBIAS } \\
\text { MESÓFILAS } \\
\text { NMP/g }\end{array}$ & $\begin{array}{l}\text { ESPOROS } \\
\text { BACTERIANOS } \\
\text { NMP } / 9\end{array}$ & $\begin{array}{l}\text { FUNGOS } \\
\text { NMP/g }\end{array}$ \\
\hline ALCACHOFRA & cápsula & $\begin{array}{l}1,4 \times 10^{5} \\
2,5 \times 10^{4}\end{array}$ & $\begin{array}{l}1,9 \times 10^{4} \\
7,7 \times 10^{4}\end{array}$ & $\begin{array}{l}<3,3(b) \\
<3,3(b)\end{array}$ \\
\hline CASTANHA DA INDIA & cápsuia & $\begin{array}{l}7,5 \times 10^{2} \\
2,5 \times 10^{3}\end{array}$ & $\begin{array}{l}2,3 \times 10^{2} \\
1,0 \times 10^{3}\end{array}$ & $\begin{array}{c}9,0(b) \\
1,4 \times 10(b)\end{array}$ \\
\hline CATUABA & cápsula & $\begin{array}{l}1,3 \times 10^{4} \\
2,5 \times 10^{3}\end{array}$ & $\begin{array}{l}1,0 \times 10^{4} \\
1,7 \times 10^{2}\end{array}$ & $\begin{array}{l}1,5 \times 10(b) \\
1,0 \times 10(b)\end{array}$ \\
\hline CENTELHA ASIÁTICA & cápsula & $\begin{array}{l}5,1 \times 10^{9} \\
4,3 \times 10^{5}\end{array}$ & $\begin{array}{l}2,5 \times 10^{4} \\
2,6 \times 10^{7}\end{array}$ & $\begin{array}{l}1,7 \times 10^{4}(b) \\
3,9 \times 10^{3}(b)\end{array}$ \\
\hline CONFREI & cápsula & $1,0 \times 10^{2}$ & $1,2 \times 10$ & $<3,3(b)$ \\
\hline ESPINHEIRA SANTA & cápsula & $2,3 \times 10^{6}$ & $2,3 \times 10^{5}$ & $<3,3(b)$ \\
\hline ESPIRULINA & cápsula & $\begin{array}{l}4.7 \times 10^{8} \\
2.5 \times 10^{6}\end{array}$ & $\begin{array}{l}3.3 \times 10^{4} \\
2,7 \times 10^{6}\end{array}$ & $\begin{array}{l}3,3(b) \\
7,7(b)\end{array}$ \\
\hline Fucus & cápsula & $\begin{array}{l}4,3 \times 10^{2} \\
2,3 \times 10^{4}\end{array}$ & $\begin{array}{l}5.1 \times 10^{2} \\
9.0 \times 10^{3}\end{array}$ & $\begin{array}{l}4.0 \\
2.3 \times 10^{2}(b)\end{array}$ \\
\hline GINSENG BRASILEIRO & cápsula & $\begin{array}{l}1,0 \times 10^{6} \\
4,3 \times 10^{5}\end{array}$ & $\begin{array}{l}1,7 \times 10^{6} \\
1,1 \times 10^{5}\end{array}$ & $\begin{array}{c}1,2 \times 10^{4}(b) \\
7,0\end{array}$ \\
\hline GUARANÁ & $\begin{array}{l}\text { cápsula } \\
\text { pó }\end{array}$ & $\begin{array}{l}2,5 \times 10^{4} \\
4,6 \times 10^{6} \\
2,4 \times 10^{5}\end{array}$ & $\begin{array}{l}9,3 \times 10^{5} \\
9,3 \times 10^{5} \\
2,4 \times 10^{6}\end{array}$ & $\begin{array}{l}2,5 \times 10^{3}(b) \\
9,3 \times 10^{3}(b) \\
1,1 \times 10^{4}(b)\end{array}$ \\
\hline LECITINA DE SOJA & cápsula & $\begin{array}{l}2,3 \times 10^{2} \\
4,8 \times 10^{3}\end{array}$ & $\begin{array}{l}2,4 \times 10^{3} \\
1,0 \times 10^{5}\end{array}$ & $\begin{array}{l}<3,0\{b\} \\
<3,3(b)\end{array}$ \\
\hline LEVEDURA OE CERVEJA & $\begin{array}{l}\text { comprimido } \\
\text { capsula }\end{array}$ & $\begin{array}{l}7,0 \times 10 \\
2,7 \times 10^{4} \\
2,3 \times 10^{3}\end{array}$ & $\begin{array}{c}9,0 \\
2,3 \times 10^{3} \\
3,9 \times 10\end{array}$ & $\begin{array}{c}<3,0(b) \\
1,0 \times 10^{2}(b) \\
1,5 \times 10^{2}\{b\} \\
7,5 \times 10(1)\end{array}$ \\
\hline óleo oe germe oe trigo & cápsula & $\begin{array}{c}<3,3 \\
2,5 \times 10^{2}\end{array}$ & $\begin{array}{l}1,0 \times 10 \\
4,3 \times 10\end{array}$ & $\begin{array}{l}<3.3(b) \\
<3,3(b)\end{array}$ \\
\hline
\end{tabular}

b-bolor

1 - Ievedura 
TABEIA XIX - Carga de microorganismos viáveis (NMP/g) das amostras do produtor $G$

\begin{tabular}{|c|c|c|c|c|}
\hline DROGA VEGETAL & FORMA FARMACÊUTICA & $\begin{array}{l}\text { BACTÉRIAS AERÓBIAS } \\
\text { MESÓFILAS }\end{array}$ & $\begin{array}{l}\text { ESPOROS } \\
\text { BACTERIANOS }\end{array}$ & BOLORES \\
\hline & & $\mathrm{NMP} / \mathrm{g}$ & $\mathrm{NMP} / \mathrm{g}$ & $\mathrm{NMP} / 9$ \\
\hline \multirow[t]{3}{*}{ GUARANÁ } & comprimido & $7,5 \times 10^{5}$ & $2,4 \times 10^{5}$ & 7,0 \\
\hline & & $2,4 \times 10^{6}$ & $2,3 \times 10^{5}$ & $2,0 \times 10$ \\
\hline & & $2,3 \times 10^{4}$ & $2.4 \times 10^{4}$ & $<3,0$ \\
\hline \multirow[t]{4}{*}{ LEVEDURA DE CERVEJA } & comprimido & 3,0 & 4,0 & 3,0 \\
\hline & & $1,7 \times 10^{2}$ & $7,1 \times 10^{\hat{2}}$ & $<3,3$ \\
\hline & & $4,3 \times 10^{2}$ & $0,4 \times 10$ & 7,0 \\
\hline & & $4,8 \times 10$ & $1.0 \times 10$ & $<3,0$ \\
\hline
\end{tabular}


TABELA XX - Carga de microorganismos viáveis (NMP/g) das amostras do produtor $\mathrm{L}$

\begin{tabular}{|c|c|c|c|c|}
\hline \multirow[t]{2}{*}{ OROGA VEGETAL } & \multirow[t]{2}{*}{ FORMA FARMACÊUTICA } & $\begin{array}{l}\text { BACTÉRIAS AERÓBIAS } \\
\text { MESÓFILAS }\end{array}$ & $\begin{array}{l}\text { ESPOROS } \\
\text { BACTERIANOS }\end{array}$ & \multirow{2}{*}{$\begin{array}{c}\text { BOLORES } \\
\text { NMP } / g\end{array}$} \\
\hline & & $\mathrm{NMP} / \mathrm{g}$ & $\mathrm{NMP} / \mathrm{g}$ & \\
\hline \multirow[t]{2}{*}{ ALCACHOFRA } & cápsula & $1,5 \times 10^{3}$ & $1,7 \times 10^{2}$ & $4,6 \times 10^{2}$ \\
\hline & & $2,5 \times 10^{3}$ & $7,5 \times 10^{2}$ & $<3,3$ \\
\hline \multirow[t]{2}{*}{ BOLDO } & comprimido & $2,3 \times 10^{4}$ & $4.3 \times 10^{3}$ & $<3.0$ \\
\hline & & $4,3 \times 10^{5}$ & $9,0 \times 10^{4}$ & $<3,0$ \\
\hline CENTELHA ASIÁTICA & cápsula & $3,9 \times 10^{5}$ & $9,0 \times 10^{3}$ & $4.6 \times 10^{4}$ \\
\hline ESPIRULINA & cápsula & $4.3 \times 10^{4}$ & $4,3 \times 10^{3}$ & 4.0 \\
\hline \multirow[t]{2}{*}{ FUCUS } & cápsula & $1,0 \times 10^{5}$ & $1,2 \times 10^{5}$ & $1.7 \times 10^{3}$ \\
\hline & & $2,7 \times 10^{5}$ & $4,3 \times 10^{3}$ & $2,3 \times 10^{3}$ \\
\hline GINSENG BRASILEIRO & comprimido & $9,3 \times 10^{7}$ & $4.3 \times 10^{3}$ & $<3,0$ \\
\hline \multirow[t]{2}{*}{ GUARANÁ } & cápsula & $4,7 \times 10^{6}$ & $9,3 \times 10^{6}$ & $1.0 \times 10^{4}$ \\
\hline & & $2,7 \times 10^{7}$ & $3,3 \times 10^{6}$ & $2.5 \times 10^{3}$ \\
\hline LECITINA OE SOJA & cápsula & $3,9 \times 10^{2}$ & $2.3 \times 10^{2}$ & $2.3 \times 10$ \\
\hline LEVEDURA OE CERVE JA & cápsula & $2,3 \times 10^{3}$ & $1,0 \times 10^{2}$ & $<3,3$ \\
\hline
\end{tabular}


TABEJA XXI - Carga de microorganismos viáveis (NMP/g) dos lotes relativos a produtores com menor amostragem

\begin{tabular}{|c|c|c|c|c|c|}
\hline \multirow[t]{2}{*}{ DROGA VEGETAL } & \multirow[t]{2}{*}{ PROOUTOR } & \multirow[t]{2}{*}{$\begin{array}{l}\text { FORMA } \\
\text { FARMACÊUTICA }\end{array}$} & $\begin{array}{l}\text { BACTÉRIAS AERÓBIAS } \\
\text { MESÓFILAS }\end{array}$ & \multirow{2}{*}{$\begin{array}{c}\text { ESPOROS } \\
\text { BACTERIANOS } \\
\text { NMP/g }\end{array}$} & \multirow{2}{*}{$\begin{array}{l}\text { FUNGOS } \\
\text { NMP/g }\end{array}$} \\
\hline & & & NMP/Q & & \\
\hline \multirow[t]{2}{*}{ ALCACHOFRA } & k & comprimido & $7,0 \times 10^{4}$ & $4,3 \times 10^{5}$ & $1,5 \times 10^{2}(b)$ \\
\hline & N & cápsula & $4,7 \times 10^{3}$ & $4,7 \times 10$ & $<3,3(b)$ \\
\hline $80 L 00$ & $c$ & pó & $4,0 \times 10^{4}$ & $9,0 \times 10^{2}$ & $9,3 \times 10(b)$ \\
\hline CARVĀO MEOICINAL & $I$ & comprimido & $6,4 \times 10^{3}$ & $2,0 \times 10^{2}$ & $9,0(b)$ \\
\hline CATUABA & M & cápsula & $2,5 \times 10^{3}$ & $8.3 \times 10^{3}$ & $2,7 \times 10^{3}(b)$ \\
\hline fucus & $\aleph$ & cápsula & $7,8 \times 10^{3}$ & $4.3 \times 10^{4}$ & $1.0 \times 10^{4}(b)$ \\
\hline GINSENG COREANO & E & cápsula & $7,8 \times 10^{4}$ & $2,5 \times 10^{4}$ & $\begin{array}{l}4,3 \times 10(b) \\
2,5 \times 10^{2}(1)\end{array}$ \\
\hline \multirow[t]{18}{*}{ GUARANá } & c & comprimido & $9,3 \times 10^{4}$ & $9,3 \times 10^{5}$ & $<3,0(b)$ \\
\hline & & & $4,3 \times 10^{4}$ & $2,3 \times 10^{5}$ & $4,6 \times 10^{3}(6)$ \\
\hline & & pó & $6.4 \times 10^{5}$ & $2,4 \times 10^{5}$ & $4,3 \times 10^{3}(b)$ \\
\hline & & & $4.3 \times 10^{4}$ & $4,3 \times 10^{4}$ & $9,3 \times 10(b)$ \\
\hline & 0 & pó & $4,3 \times 10^{5}$ & $4,3 \times 10^{4}$ & $7,5 \times 10(b)$ \\
\hline & $H$ & comprimido & $4,3 \times 10^{5}$ & $4.3 \times 10^{4}$ & $4,0(t)$ \\
\hline & & pó & $2,4 \times 10^{\hat{0}}$ & $4.3 \times 10^{5}$ & $7,5 \times 10^{2}(0)$ \\
\hline & & & $2.3 \times 10^{5}$ & $4,3 \times 10^{5}$ & $2.6 \times 10^{5}(b)$ \\
\hline & & & $2,3 \times 10^{5}$ & $4,3 \times 10^{5}$ & $2.4 \times 10^{5}(b)$ \\
\hline & Ј & pó & $4,3 \times 10^{3}$ & $4,7 \times 10^{2}$ & $1,5 \times 10^{4}(b)$ \\
\hline & & & $4,3 \times 10^{3}$ & $3.9 \times 10^{2}$ & $2.1 \times 10(b)$ \\
\hline & k & pó & 3,0 & $<3,0$ & $4.0 \times 10(b)$ \\
\hline & & & $4,3 \times 10^{2}$ & $4,0 \times 10^{3}$ & $9,0(b)$ \\
\hline & N & comprimido & $7,5 \times 10^{5}$ & $2,4 \times 10^{5}$ & $7,0(b)$ \\
\hline & $p$ & pó & $4,3 \times 10^{4}$ & $2,4 \times 10^{4}$ & $4,6 \times 10^{4}(b)$ \\
\hline & R & pó & $1,5 \times 10^{6}$ & $2,3 \times 10^{6}$ & $4,6 \times 10^{4}(b)$ \\
\hline & $s$ & pó & $2.3 \times 10^{4}$ & $3,9 \times 10^{3}$ & $\begin{array}{l}2,3 \times 10^{3}(b) \\
7,5 \times 10^{3}(1)\end{array}$ \\
\hline & $i$ & pó & $1,4 \times 10^{5}$ & $2,3 \times 10^{4}$ & $6,4 \times 10(b)$ \\
\hline LECIIINA DE SOJA & $Q$ & cápsula & $4,3 \times 10^{2}$ & $9,3 \times 10^{2}$ & $7,0(1)$ \\
\hline \multirow[t]{2}{*}{ LEVEDURA DE CERVEJA } & H & comprimido & $7,0 \times 10$ & $2,3 \times 10$ & $3.0(b)$ \\
\hline & & & $1,2 \times 10^{3}$ & $4,3 \times 10^{2}$ & $c 3,0(b)$ \\
\hline \multirow[t]{2}{*}{ ÓLEO OE GERME OE TRIGO } & 0 & cápsula & $<3,3$ & $1,0 \times 10$ & $<3,3\{b\}$ \\
\hline & 0 & cápsula & 4,0 & 4,0 & $4,0(b)$ \\
\hline ZEDOÁRIÁ & f & cápsula & $2.5 \times 10^{2}$ & 3,3 & $<3.3(b)$ \\
\hline
\end{tabular}




\section{DISCUSSÃO}

\subsection{Considerações gerais}

A "Fitoterapia" è um termo proveniente da fusão de duas palavras gregas "phuton" = planta e "therapeuein" = tratar, curar, sendo conhe cida como "tratamento ou medicina pelas plantas" $(16,103,115,135,144)$. Há, porèm, a tendència em confundi-la com "Fitofarmäcia", constituindo a parte da Farmácia que "trata do preparo de produtos destinados a proteger as plantas e gêneros de origem vegetal contra ação nociva de vários parasitas ou microorganismos, bem como da elaboração de preparaçóes tóxicas para os animais prejudiciais às culturas e aos gēneros úteis ao homeril: (115) ou aindia "o estudo das preparações antiparasitárias destinadas ao tratamento das doenças das plantas" (57).

Ao conceituar "Fitoterápico", deve-se fazé-10, primeiramente de "Drogas", cuja prōpria definição, por sua vez, apresenta variação. 0 termo provém de "droog", palavra holandesa significando "seco" (155) e do per sa "droa" = odor (136), visto que muitas apresentam odor mais ou menos acentuado. Vuigarmente, corresponde a qualquer substância contida em medica mento, empregado interna ou externamente para o tratamento, cura ou preven ção de doenças (58), o que parece redundante, uma vez que constitui a própria definição de medicamento $(24,70)$. Pode, até mesmo, considerar "Droga" qualquér preparação narcótica $(58,193)$, sendo que a legislação brasileira (24) acrescenta-lhe, ainda, a finalidade sanitária. São tambén conceitua das como matéria-prima para a preparação de medicamentos oficinais e magis trais, medicamentos simples ou brutos, produtos de obtenção imediata ou ainda, partes de vegetais como folhas, raízes, gomas etc., bem como produtos animais ou de sintese $(44,69,136,156)$. Essa útıima se asseme tha à definição da Farmacopéia Helvética (153) que considera como "droga medici- 
nal" não apenas drogas ou partes de örgãos de origem vegetal, animal ou hu mana, como também, as misturas de substancias destas mesmas origens.

Em Farmacognosia, as "Drogas" são "vegetais, animais ou ainda partes deles, que, após sofrerem processos de coleta e de conservação, pos suem composição e propriedades tais que possibilitem o seu uso como forma bruta de medicação ou como necessidade farmacéutica" (142).

No presente trabalho, adotou-se o termo "especialidade fitoterápica", considerando, supostamente, que as amostras continham partes vege tais, produtos derivados e atè extratos, à semelhança de Negretti (131), pois, este usou o termo "fitoteräpico" para referir-se a matérias-primas na turais (vegetais) e aos derivados sob a forma de óleos essenciais (essên cias), tinturas, extrato fluido e seco.

\subsection{Apresentação comercial das amostras}

A abrangência da amostragem de fitoterápicos para este estudo, no decorrer de 2 anos, ficou na dependēncia mercadológica, razão pela qual muitos produtos não foram possiveis de serem analisados en mais de 1 lote. No caso de produtor que não apresentava recurso para identificação do ciclo produtivo a aquisição da amostra foi efetuada após alguns meses, na su posição de que se tratasse de outro lote e este critério, somado à caracte rística efêmera de muitos destes produtos, acabou limitando a amostragem. Procurou-se, todavia, abranger maior variedade de drogas vegetais comercia lizadas na forma farmacéutica sólida.

Conforme a relação da Tabela I (og. 51), esía abrangência refletiu, inclusive, interesse de comercialização direcionado para uma deter minada droga por parte de muitos producores como ocorreu com guaraná. Apesar disto, houve inconstäncia, pois quando se procurou outros lotes do mes mo produto, de determinado fabricante, não mais se encontrava à venda. Ain 
da com relação aos produtores verificou-se aparente tendéncia de regionali zação, uma vez que houve predomináncia de empresas paulistas envolvidas nesta amostragem, conforme a relação da Tabela III (pg. 53).

Considerando a legislação sanitária vigente para "medicamentos, drogas, correlatos, cosméticos, produtos de higiene, saneantes e outros" regulamentada pelo decreto 79094 de 5 de janeiro de 1977 (24), apesar de não fazer menção específica aos produtos fitoterápicos, esces deven ser en quadrados como medicamentos alopáticos. Todavia, isto não póde ser observa do, de forma geral, em relação aos produtos analisados.

Dentre as exigéncias legais pertinentes à apresentação comer cial, alguns pontos fundamentais foram observados. Conforme a Tabela I lpg. 51), a questão da bula teve que ser observada segundo dois aspectos, a saber: inclusão de material impresso avulso dentro da embalagem secundäria (a), contendo as informaçōes pertinentes ao produto, assimi como informação exigida por lei, embora impressa no pröprio rötulo (r) e/ou cartucho (c). No primeiro caso, apenas 5 anostras, fabricadas por 5 diferentes produto res $(E, F, M, I, J)$ obedeceram a este critério. Em contraposição, 43 amostras não continham na apresentação comercial qualquer informação sobre o produ to, correspondendo a 6 diferentes produtores $(B, C, G, H, L, N)$. Houve omissão integral no caso do produtor $B$, cuja gana de especialidades fitoterápicas amostradas indica ser fabricante com grande fatia de mercado (26 lotes). Apesar disto, rião atende aos requisitos legais. Outro produtor (L) que está na situação intermediária, pelo fato de incluir informações no rótulo e cartucho, também foi coerente dentro deste critério em relação às 12 amostras dentre 13 lotes de diferentes fitoterápicos.

A baixa frequencia de inclusão de bula no interior da embâla gem secundäria pode ser atribuída ao decreto $n=83239$, de 6 de março de 1979 (25), que retifica o decreto $n=79094$ (24) referido anteriormenite, no qual é dispensado tâl impresso para medicamentos que não apresentar "con - 
tra-indicações" de uso ou esclarecimentos quanto a efeitos colaterais, des de que seja mencionado na rotulagem ou embalagem externa o modo de usar ou de aplicar o produto". Porém, é sabido que a inocuidade das drogas vegetais está limitada à dose, e portanto, a declaração de "ausência de toxicidade" verificada em 14 lotes correspondentes a 10 produtos (Tabela III) (pg. 53), baseada no conceitó de que "sendo natural faz bem" não deve ser apresentado como base do incentivo e propaganda ao emprego da fitoterapia.

Nesta amostragem, 25 lotes correspondendo a 20 produtos incluem os dizeres "produto natural" (Tabela III) (pg. 53), cuja mensagem poderia ser enquadrada cono não condizente com o artigo 93, parágrafo úrico, da retificação de 1979 (25) que proibe a apresentação, na rotulagem ou publicidade e propaganda do produto, de indicaçōes que possibilitem a interpretação falsa, erro ou confusão quanto à origen, procedência, natureza, composição, ou qualidade, ou que atribuam ao mesmo finalidades ou características diferentes das que realmente possui. Porém uma especialidade contendo zedoária (produtor $F$ ) apresentou, na bula, o ítem precauções fazendo menção de que "mesmo sem a existẽncia de referèncias sobre a teratoge nia, recomenda-se não usar o produto no primeiro trimestre de gestação e na lactação".

Num outro produto, (catuaba, produtor M) havia adverténcias se melhantes, além da "administração preferencial a adultos". Ainda, no caso de zedoäria foran descritas as reações adversas, diferentemente daquela de catuaba que apenas recomenda o uso das doses indicadas, no sentido de "evi tar reações desagradăveis". Portanto, ambas apresentam preocupação com o consumidor, demonstrando seriedade para com os produtos fitoterápicos.

Contrariamente, apenas $i$ amostra de ginseng brasileiro (produtor E) apresentou afirmação de que "o produto não apresenta contra-indicações, nem restrições e cuidados a considerar quanto ao seu uso, já que trá ta-se de produto genuinamente vegetal". Neste caso foi flagrante a desobe- 
diència ao artigo 93 referido anteriormente (25).

Ainda com relação à natureza ou tipo de informação constante no material impresso, en 33 amostras configurou, no rótulo da embalagen, a quantidade da droga, em miligramas (Tabela III) (pg. 53). Embora tenha a presentado esta informação, nem sempre constou a posología. A omissão dessas informações foge aos requisitos em vigor, além de que todas essas espe cialidades farmacẽuticas estão sendo comercializadas sem prescrição médica.

Conforme os dados da Tabela I (pg. 51), com relação à identifi cação do ciclo produtivo foi considerada, nesta observação, a presença do impresso referindo-se ao nümero de lote e data de fabricação. Sendo assim, mais da metade $(61,9 \%)$ dos 84 lotes amostrados incluiam o lote, seja em etiqueta, no rótulo ou no cartucho. Apesar da exigéncia legal, a informação referente à data de fabricação nem sempre esteve presente junto ao nümero do lote, o mesno podendo ser dito quanto à data, pois em algumas amostras não constou o número de lote e sim, apenas a data de fabricação. Dentre es tas amostras, o produtorl, cujos produtos amostrados compreendem 9 drogas diferentes, com 13 lotes analisados, desobedeceu integralmente esta ültina exigên cia. No caso de produtores cujas amostras foram representadas por pequeno número de lotes não se pode tecer comentários.

4 informação que caracteriza o ciclo produtivo geralmente estava contida en etiqueta, sempre colada na embalagem prinária e em algumas, na base do frasco, dificultando o acesso a esta informação pelo consumicor.

Com referéncia à estabilidade e consequente prazo de validade, normalmente o tempo de vida útil recomendado para as drogas vegetais "per se" é de 1 ano $(71,143,144)$, embora, com algumas exceções. Todavia, entre os produtos amostrados neste estudo houve predomináncia para 3 anos, pois, 32 dos 46 lotes que apresentaram prazo de validade assim estavam sendo comercializados. Apenas 3 lotes apresentavâm prazo de validade de 1 ano, em contraposição a 5 anos, para 5 lotes, o que deve ser tempo milto iongo, 
implicando na redução de atividade terapéutica. Portanto, é discutivel a estabilidade dos princípios ativos nestas condições.

0 aspecto quanto à omissão de prazo de validade de cada lote é preocupante, mas o extreno oposto com 5 anos de vida util pode ser questio nável, tendo em vista a heterogeneidade inerente às drogas vegetais, cuja complexidade quanto ao seu conteúdo é fator favorável na aceleração da ins tabilidade dos seus componentes.

Pela observação macroscópica das amostras de óleo de germe de trigo en cäpsulas havia sinais de deterioração, pois, estas se apresentavam intumescidas e aderentes à parede do frasco. No entanto, o prazo de va lidade inscrito era de 3 anos e no momento desta ocorréncia haviam decorrido 2 anos após a data de sua fabricação.

Sabe-se que a natureza do material de acondicionamento (embala gem primäria) pode interferir na estabilidade do seu conteúdo. Observando os dados da Tabela I (PS. 51), naqueles casos de amostras com 5 anos de prazo de validade, apenas 2 lotes de comprimido de guaraná do produtor C estavam acondicionados em frasco de vidro. Na quase totalidade houve prefe rência pelo material plástico lós lotes em frasco de plástico, 5 em saco plástico, 3 como blister" e 1 como envelope de papel plastificadol, seguido de frasco de vidro (7 lotes) e fibra-lata (2 lotes).

A comerciâlização de especialidades fitoterápicas sen a embala gem secundäria é marcante, visto que apenas 24 amostras estavam embaladas em material celulósico, seja como cartucho (2l lotes) ou embalagem cilindrica ( 3 lotes). A auséncia de embalagem secundária assume iriportáncia maior quando se considera o fato de que a grande maioria dos frascos plásticos era transparente. Assim, a degradação dos princípios ativos pela ação da luz far-se-á presente e o pràzo de validade de 3 a 5 anos, nestes produtos, torna-se preocupante. 
Ainda com relação ao material gräfico, a omissão do responsável técnico é desobediéncia grave à legislação en vigor. Conforme a Tabela I (pg. 51), dentre os produtores envolvidos nesta amostragem, 7 estão em desacordo. 0 produtor $L$, também neste aspecto, demonstrou estar em desacordo, pois, em 3 produtos dentre 9 amostrados não constou o nome do responsável técnico. Considerando a legislação sanitária vigente (Artigo 95 do Título X) (25) que trata da rotulagem e publicidade de medicamentos, verificou-se que apenas 15 lotes $(17,9 \%)$ foram condizentes integralmente com a norma no que se refere a bula, número de lote, responsāvel técnico, data de fabrica ção e prazo de validade. Os fabricantes correspondentes for am 5 , sendo que os produtores A, $M$ e 0 cumpriran con tais exigëncias en todos os lotes amostrados. Todavia estes dois últimos não apresentam significância, tendo em vista a amostragem reduzida em relação ao A, com 9 lotes. Os outros produtores, $C$ e $K$, obedeceram-nas, respectivamente, com frequéncia de $2 / 5$ e $2 / 3$, indicando falta de critério.

Analisando outras informações constantes no materià impresso que acompanha a apresentação comercial dos produtos, conforme os dados da Tabela II (pg. 52), en confronto à legislação en vigor, muitos não informan os dados de registro en órgão oficial competente. Dos 84 lotes, 54 não atenderam a esta exigéncia. Os procutores $B, C$ e L seguiram as normas em parte das amostras, o que indica falta de paóronização. Entre as amostras registradas juncico ao Ministério da Saúde, apenas 4 faziam menção à DIMED e 2, à DJNÁl. Situação extrema foi observada con o pó de guâraná do produtor $J$, com registro eni ministérios diferentes.

Os dados da Tabelà II (pg. 52) podern ser reflexo da controvérsia existente quanto à conceituação deste tipo de produtos como sendo medi camentos ou alimentos. Isto fica ainca mais caracterizado quando o mesmo produtor registra lecitina de soja junto ao DIMEO e óleo de germe de trigo, junto ao DINAL (produtor Q), dando destaque ao termo "alimento dietético". 
Eonforme os dados da Tabela III (pg. 53), 3 amostras, 1 a base de lecitina de soja e as outras 2 correspondendo a óleo de germe de trigo (Produtor A) apresentavan a conotação "complemento nutritivo", con indicação em "dietas especiais", sem entretanto, informar o órgão competente (Tá bela II) (pg. 52). Estes fatos, igualmente, evidenciam a auséncia de padronização.

Além destes, outros 3 loces contendo lecitina de soja, espirulina e centelha asiätica, fabricados por $L$ apresentarám reconenáação de uso cono "auxiliar nos regimes de emagrecimento".

Portanto, todas estas amostràs enquadram-se na definição legal de produto dietético (artigo 3o das Disposições Preliminares do Título I) (24), porén não estão en conformidade con o artigo 112 do Título $X$ que prevê, para estes produtos, a especificação no rótulo e demais impres sos que os acompanharin, do resultado áproximado da análise percentual dos componentes en que se baseia à utilização dietética especial, o que não foi verificado nestas amostras.

Há portanto falta de clareza a definição quanzo aos conceitos de medicamento, complenento alinentar e alimento dietético en ruitos produ tos analisados.

Värios lotes de guaraná constituiram outra eviciencia do fato, visto que 1 amostra apresentou à inscrição "alimento naturāl" (Produtor P) sem informaçãc quanto ao seu registro a 3 com registro no kinisiério da Saúde, com indicação no tratamento de astenia muscular (Produtor A). Outro produto contendo a mesma droga vegetal foi registrado junto co vinisté rio da Agricultura e na sua bula confiçurava a lista dos componentes quíi cos da pasta endurecida, descrevendo suas propriedades terapêuticas (Produ tor J).

A renção de Farmacopéia Brasileira, exigicà por lei para produ 
tos oficinais (24) foi verificada apenas em 6 amostras correspondentes a 4 produtores $(C, F, I, P)$, sendo que outros 4 lotes de 2 produtores $(K, H)$ apenas apresentaram os dizeres "produto oficinal".

Sernelhantemente, a legislação (24) exige que nos rötulos de me dicamentos homeopáticos constem os dizeres "Fârnalacopéiã Homeopática Brasileira". Desta formâ, isto se verificou em produtos de 3 fabricantes (8, C, H), principalmente do 8 . Porém os producos correspondentes não apresenta ran discrininação da escala e dinamização, conforme regulanenta a lei. Alëm de que não constarabi sequer as indicações terapêtuticas a que se restringen as exigèncias (parágrafo único do artigo ic2) (24) para as bulas de produtos homeopáticos.

Considerando a variedade de espécies vegerais reunidas sob o mesno gènero e a importáncia da icentidacie botänica, seria desejāvel seu reconhecimento analîtico åravés da dencrinação ciencíficâ.

Conforrie a Tabelà III (og. 53i, o none cientifico roi mencioną do en 9 cas 17 espécies botänicas, poréri, nem seripre de forria correta, em conformidade com as regras de nomenclatura cientifica (142). Neste estudo não foi feita a comprovação farmacognóstica das espécies vegetais declaradas no rótulo dos produtos amostrados para avaliação do grau de contaminação microbiana. Em vista disto, preferiu-se atribuir nomenclatura vulgar ao conteúdo botânico destas especialidades farmacêuticas, cuja denominação co mercial quase sempre foi coincidente.

A falta de padronização e cumprimento à legislação no tocante à comercialização destes produtos podem ser atribuidas à pröpria falha ou omissão no decreto pertinente, uma vez que as especialidades fitaterápicas apresentam caracteristicas específicas. Portanto, è desejável que haja atualização na lei com regulamentação desta gama de medicamentos hoje tão amplamente exploradose consumidos sem que haja critérios, seja como alopático, dietético, homeopático ou alimento. 


\subsection{Métodos}

\section{3.l Tratamento das amostras}

Considerando as características das amostras, empregaram-se re cursos adequados, de forma a garantir o contato intimo destas com o meio de cultura.

Os comprimidos foram reduzidos a pó através de trituração. No caso de cápsulas, tanto a gelatinosa dura como mole, a anālise foi conjunta, sem se preocupar apenas com o conteúdo vegetal. Isto porque o paciente ingere a cápsula como um todo e o risco a que se expõe o mesmo independe da origem da contaminação, se da gelatina ou do próprio fitoterápico.

Com relação ao recurso para facilitar a dispersão e dissolução da gelatina, recorreu-se ao aquecimento do conjunto amostra-diluente, conforme as recomendações oficiais pertinentes à anälise de cápsulas vazias de gelatina. Nesse particular, há variação nas condições anaijiticas de ten po e temperatura, sendo que a temperatura recomendada reside entre 40 a $45^{\circ} \mathrm{C}$, por tempo não superior a 30 minutos $(34,205,208)$. Segundo Ferreira e Freitas (72) o aquecimento de amostra sob forma de suspensão facilita a re moção das bactérias aderidas às particulas. Esses autores estudaram tal fato através do aquecimento de suspensão de amostra de taico, atribuindo ao abaixamento da tensão superficial, decorrente ao efeito do recurso térmico, maior recuperação dos microorganismos viäveis. Ainda, com relação à nature za do diluente, estudaram vărias soluções, contendo ou não tensoativos. A solução salina de tampào fosfato, seguida de solução de Ringer e de salina foram as melhores dentre aquelas sem o tensoativo. No estudo efetuado por Buhlman e colaboradores (37), o polissorbato 80 foi recomendado para facilitar a dispersão de partículas das amostras constituidas por comprimidos, drägeas e pós. 
De acordo com Ferreira e Freitas (72), o melhor agente umectan te foi o polissorbato 80 , seguido de citrato de sódio e monoestearato de glicerila. Além disso, a melhor combinação diluente-agente umectante foi solução salina-tampão fosfato acrescida de $0,1 \%$ de polissorbato 80 .

Os métodos oficiais para anālise de medicamentos não estéries $(34,47,133,134)$ fazem recomendação para uso de agentes umectantes no diluente para preparo das amostras, cuja concentração varia de 0,1 a $1,0 \%$. Entre os tensoativos, tanto o polissorbato 20 como 080 são recomendados.

Neste trabalho, levando em consideração a dificuldade de homogeneização das partículas em suspensão, bem como pela necessidade em emulsificar algumas amostras lipófilas de óleo de germe de trigo, decidiu-se pela adição de $0,5 \%(p / v)$ de polissorbato 80 à solução salina $0,9 \%$.

\subsubsection{Detecção de contaminantes viáveis}

Respeitando a representatividade das amostras e a validade ana lítica, a tomada de ensaio foi em função da quantidade de amostra disponível, tendo-se considerado, de inicio, a necessidade potencial de repetição dos testes e o número de provas que seriam realizadas.

Empregaram-se $5 \mathrm{~g}$ de cada amostra para o preparo da diluição $10^{-1}$. Porém, na literatura encontram-se tomadas menores como de $19(23,69$, $72,213)$ e $2 \mathrm{~g}(146)$; foi mais usada a de $10 \mathrm{~g}(37,47,72,92,133,134)$. Evidentemente que a melhor representatividade reside em tomada de ensaio cada vez maior, razão pela qual os métodos oficiais em vigor recomendam a tomada de $10 \mathrm{~g}(34,47,133,134,208)$.

Com vistas à validação do método analítico para a determinação dos contaminantes microbianos viáveis, em função das características deste tipo de amostras, foi realizado o ensaio prévio, tendo-se testado as técni cas de semeadura em profundidade e dos tubos mültiplos, usando 3 amostras. 
Os resultados das contagens bacterianas totais obtidos foram confrontadose pode-se verificar a coeréncia entre os valores encontrados, tendo sido de mesma ordem de grandeza. Constatação semeihante foi verificada por Fischer e colaboradores (73) da Dinamarca, em 1968, na análise de comprimidos produzidos em farmäcias e em indústrias, incluindo alguns contendo drogas ou substâncias de origem vegetal. No mesmo ano, Smidt e Ulrich (184) avalia ram lotes de comprimidos de produção industrial, através das mesmas técnicas e os resultados obtidos demonstraram a semelhança com os daqueles auto res. Entretanto, segundo Romond (170), nos casos de carga bacteriana baixa, a sensibilidade do método em caldo se mostrou maior. Além disso, o mesmo autor menciona como vantagem a possibilidade de aplicação desta técrica para qualquer natureza da amostra. A FIP (47) apresenta esse método como sendo adequado para amostras insoluveis em áqua, de natureza não lipófila, quando a carga contaminante viável é inferior a $10^{2} / \mathrm{g}$ ( $\mathrm{mL}$ ), com resultado mais exato.

Considerando a natureza das amostras, constituídas de drogas vegetais trituradas ou pulverizadas, encapsuladas in natura ou sob a forma de comprimidos, merece tecer alguns comentários. Sabe-se que toda droga ve getal passa por algum processo de secagem visando sua conservação $(50,143$, 144).

A temperatura para dessecação varia de acordo com a parte da planta, sendo, segundo Paris e Moyse (144) de 20 a $40^{\circ} \mathrm{C}$ para sumidades flo ridas e folhas e de até $60-70^{\circ} \mathrm{C}$ para as cascas e raizes, o que contrasta com as temperaturas de 35 a $40^{\circ} \mathrm{C}$ usualmente empregadas e recomendadas (143) a fim de não alterar os princípios ativos.

Prara a estabilização empregam-se temperaturas mais elevadas por curto espaço de tempo. Geralmente se faz uso de calor seco a $80^{\circ} \mathrm{C}$ por até 30 minutos $(50,143,144)$. Além disso, a aplicação adicional de aquecimento irá ocorrer quando as drogas são processadas para serem consumidas sob a 
forma de comprimidos. Assim, a secagem dos granulados requer temperatura maior que ambiente, por exemplo, de 40 a $50^{\circ} \mathrm{C}$ durante 4 a 5 horas (163).

Desta forma, microorganismos presentes nas drogas estariam, após sucessivos tratamentos, debilitados pelas condiçóes adversas. Tendo em vista, adicionalmente, a relação direta entre a atividade de água e a dete rioração do produto $(139,143)$, no caso das formas sölidas estudadas, era de se esperar que os valores das contagens fossem baixos, o que levou, em primeira instäncia, à escolha do método de tubos mültiplos. Nesse aspecto, Romond (170) recomendou, inclusive, o uso de caldo de dupla concentração.

Além disto, outra vantagem da metodologia consiste em permitir melhor revitalização dos microorganismos traumatizados em função do perfei to contato da amostra com o meio de cultura $(138,170)$. Neste caso, o uso de meio sölido fundido seria fator adicional de "stress" (167), uma vez que a temperatura do meio não seria favorável aos microorganismos debilita dos. A Farmacopéia Americana (208) recomenda o uso da técnica dos tubos múltiplos em caso de amostras pouco solúveis e translúcidas.

Os produtos amostrados para este estudo enquadram-se nesta des crição, além de que as diluições iniciais da amostra inoculadasem meio sólido levariam a düvidas na diferenciação entre o crescimento microbiano e particulas das amostras. Mesmo com a técnica de tubos mültiplos, dependendo da natureza da amostra e do nivel de contaminação, houve necessidade de comprovação do crescimento microbiano através de sub-culturas. 0 inconve niente, neste caso, relaciona-se a gasto adicional de material e de tempo. Portanto, em anālises de rotina é preferivel o emprego da técnica de ágar fundido, sobretudo se o nivel de contaminação for elevado, uma vez que, nes te caso, é viável a realização de diluições mais altas, eliminando-se a in terferencia das particulas do produto na leitura dos resultados.

Na realização de sub-culturas, a FIP (47) sugere o emprego do meio sölido correspondente, com incubação nas mesmas condições de tempera- 
tura $\left(30-35^{\circ} \mathrm{C}\right)$ por 48 a 72 horas. A Nota Técnica Pró Farmacopéia no 189 (133), porèm, recomenda, indistintamente a necessidade da sub-cultura em meio $l \hat{i}$ quido ou sôlido, assim como a Farmacopéia Britänica (34). A Farmacopéia Americana (208) não apresenta tal orientação.

Outro inconveniente do método è a baixà precisão $(2,13,118,137)$, uma vez que a determinação do Nümero Mais Provável (NMP) se baseia em esti mativa fundamentada em probabilidade (2). Assim indica o valor dentro de $\underline{u}$ ma faixa e que reflete o nümero de microorganismos presentes (118).

Barzaghi e colaboradores (13) compararam os métodos de NMP, de placa e da filtração, tendo verificado a imprecisão do primeiro.

Com o prosseguimento das anälises verificou-se que muitas das amostras de fitoterápicos estavam altamente contaminadas, em niveis supe riores ao esperado. Desta forma, em alguns casos testaram-se as diluições altas, até da ordem de $30^{-7}$ a $10^{-10}$.

Buogo e Ratti (40) igualmente fizeram uso da mesma técnica, ten do chegado à conclusão de que esse método è perfeitamente viável na análise bacteriológica de medicamentos, inclusive, durante o processo produtivo, com a determinação do NMP dos contaminantes totais (bacterianos e füngicos). Os autores realizaram, paralelamente, a contagem empregando o meío sólido.

A técnica de tubo múltiplo é muito utilizada na determinação de coliformes em alimentos, águas e solos $(2,7,52,123,137)$, sendo também recomendada como método oficial para controle microbiológico de medicamentos $(34,47,70,133,170,208)$. Lingnan (111) testou-a para controle de maté rias-primas.

Neste trabalho, a escolha do caldo caseina-soja como meio de cultura na determinação de bactérias aeróbias mesófilas residiu nas recomendações oficiais $(13,34,47,49,70,133,208)$, embora alguns autores tenham utilizado o caldo tioglicolato $(40,73)$. I gualmente, embora com pequenas va 
riações, o tempo de incubação recomendado vai até 5 dias, para temperatura variando de 30 a $37^{\circ} \mathrm{C}$. Neste estudo optou-se pela incubação em estufa $36 \pm$ $1^{\circ} \mathrm{C}$ durante 3 dias.

Com relação à técnica para determinação de fungos, optou-se, neste trabalno, pelo uso de apenas 1 antibiótico, a tetraciclina, na concentração de 100mg/L de caldo Sabouraud-dextrose. Verificou-se na maioria dos casos, eficiēncia na inibição do crescimento bacteriano, porém, em outros, quando foi observada turvação no meio, efetuou-se esfregaço e colora ção de Gram, a fim de confirmar a natureza do desenvolvimento microbiano, conforme orientação da FIP (47).

A solução do antibiótico foi esterilizada por filtração, antes de ser adicionada ao meio de cultura, embora houvessem autores que acharam desnecessário esse procedimento se fossem observados cuidados adequados durante o seu preparo.

A positividade para o crescimento de bolores foi baseada na formação de micélio filamentoso, de observação macroscópica fácil, no meio de cultura líquido.

Ao testar-se o uso do meio de cultura sólido contendo a combinação de cicloheximida $(400 \mathrm{mg} / \mathrm{L})$ e cloranfenicol $(50 \mathrm{mg} / \mathrm{L})$ observou-se 0 desenvolvimento de bactérias resistentes, fato confirmado através de obser vação microscópica após coloração de Gram das colónias com caracteristicas bacterianas. Portanto, camparado ao caldo empregado para a contagem contendo apenas tetraciclina, pode-se considerar o caráter inibitório do crescimento bacteriano deste üitimo, satisfatório.

Quanto às condições de incubação, apesar das variações em função de autores $(7,70,96,116,133,170,208)$ se adotou o tempo de 7 dias, a 20$25^{\circ} \mathrm{C}$. Sabe-se, porém que é viável, também, o uso de incubação à temperatura ambiente, sempre que não se dispõe de incubação controlada a temperaturas baixas. Neste caso, deve-se anotar o fato e inclusive a faixa de variação da temperatura (96). 
Na busca de recursos para a obtençäo de resultados mais räpidos, Mead e 0'Neil (116) desenvolveram um método analitico para a recupera ção de bolores que levou 3 dias, fundamentado no controle adequado de temperatura de incubação (entre 27 e $28^{\circ} \mathrm{C}$ ), em substituição à temperatura ambiente, além do uso de meio de cultura contendo alto teor de nutriente, com tamponamento pröximo à neutraitidade, no lugar de pH ácido. Ainda tiveram que evitar a perda de umidade do meio sölido e acrescentaram cloranfenicol $(0,01 \mathrm{mg} / \mathrm{mL})$ para evitar a contaminação bacteriana.

0 procedimento para determinação de esporos visou a eliminação de formas vegetativas, usando a suspensão da amostra de diluição correspon dente a $10^{-1}$. O tratamento térmico usado por diversos autores indica cond ções que não afetem a viabilidade de esporos menos termoresistentes (125, 194), até outras mais drásticas (138).

Neste trabalho, optou-se por aquecimento a $80 \pm 1^{\circ} \mathrm{C}$, por $10 \mathrm{mi}$ nutos, como foi a técnica empregada por Romond (170) e Pedersen e Szabo (146). A determinação foi pela técnica do tubo múltiplo, visando favorecer o contato dos nutrientes com os esporos, por vezes estressados durante a secagem da droga, bem como na ミetapa de granulado, em se tratando de comprimidos.

Com vistas à obtenção de resultados fiēis, sob o ponto de vista quantitativo, uma vez que os esporos podem estar diferentemente estressados, as condições para germinação devem ser favoráveis. Para isto, Ray e Adams Jr. (167) recomendam a adição de amido ao meio de cultura de recuperação para adsớção de possiveis agentes inibidores, assim como a inclusão de lisozima para facilitar a germinação de esporos lesados.

Como a pesquisa de patogénicos específicos é ensaio limite, na tomada de ensaio deve ter havido preocupação quanto à representatividade e sensibilidade, a fim de poder efetuar o confronto com a especificação em questão. 
A Farmacopéia Americana, por exemplo, até a 17ạ edição (203) e xigia a auséncia de Escherichia coli em $10 \mathrm{mg}$ de gelatina, cujo padrão foi alterado a partir da edição seguinte para $10 \mathrm{~g}$. A recomendação oficial brị tânica, mesmo na edição de 1980 (33) ainda faz menção a 1 g; com detalhes para melhor representatividade na tomada de ensaio, preparando a diluição $10^{-1}$ com $10 \mathrm{~g}$ de amostra, na edição de $1988(34)$.

Neste estudo, partiu-se de $10 \mathrm{~mL}$ da suspensão da amostra correspondente à diluição $10^{-1}$, una vez que o padrão microbiano a ser usado foi o da FIP (47), embora critérios oficiais mais recentes sejam bem mais exigentes. Alem disto, defrontou-se com a exiguidade de amostra conforme já comentado por ocasião da amostragem.

Tendo em vista a origem vegetal das amostras e o direcionamento da pesquisa de microorganismos especificos para aqueles com implicação direta com a via de administração destes produtos, optou-se pelo isolamento de indicadores da contaminação fecal. Para isto, tendo seguido metodologia com tendéncia norte-americana (123) para a pesquisa de Escherichia coli, diferentemente da oritânica que considera suficiente o uso de caldo MC Conkey e a formação de gás como evidencia da presença de coliformes totais. Os métodos para isolamento ou análise diferenciada de coliformes estão baseados naqueles para anălise de água $(2,106)$, dos quais deriva ram aqueles para alimentos (123).

A literatura refere-se ao emprego de variadas sequências anali ticas e meios de cultura com a mesma finalidade, tendo-se adotado aqueles mais adaptados aos recursos laboratoriais disponiveis (123).

Hä abundante bibliografia relativa ao valor de Escherichia coli e da famīila Enterobacteriaceae como indicadores de contaminação fecal (123). Esses indicadores devem ter capacidade de sobrevivéncia em ambien tes diferentes do trato intestinal (34). 
0 termo "coliformes" compreende Escherichia coli e diversas es pécies pertencentes a outros géneros da famijia Enterobacteriaceae (123). - grupo não apresenta características uniformes quanto à especificidade de habitat e tempo de sobrevivencia em ambiente diverso do trato intestinal (106).

Na prova para coliformes è possivel detectar-se, geraimente, os gëneros Escherichia, Citrobacter, Klebsiella, Yersinia $(105,123)$.

En contraste, o grupo de coliformes fecais fornece maior especificidade fecal que os coliformes, visto possuir maior incidencia de Escherichia coli $(105,106,178)$. Ainda assim, também estão incluídos outros membros do mesmo género e outros gẽneros como Klebsiella e Enterobacter (118).

E importante lembrar que, espécies bacterianas do gênero Erwinia, Serratia (123) e Klebsiella (187) fazem parte da microflora natural dos vegetais. Assim, uma reação positiva para coliformes fecais pode ser induzida por essas bactérias.

Fica evidente, portanto, que os termos "coliforme" e "coliforme fecal" não possuem validade taxonönica (118), o que torna claro o signi ficado das contagens de coliformes fecais, apenas quando expressas em termos do procedimento analítico usado e do produto acabado (118).

0 procedimento com uso sequencial de meios, cada vez mais sele tivos, normalmente, é empregado com a finalidade de melhorar $\supset$ isolamento

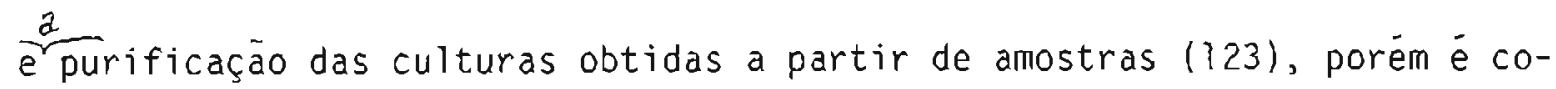
mum a realização dos testes para os diferentes tipos de coliformes isolada mente $(2,52)$, isto é, usar-se cada meio de enriquecimento seletivo ou de isolamento após o respectivo enriquecimento não seletivo.

Empregou-se, inicialmente, caldo lactose, seguido de caldo lac tose-bile-verde brilhante com confirmação do crescimento dos tubos 
positivos para a fermentação da lactose em àgar eosina-azul de metileno com anälise macromorfológica e posterior confirmação bioquímica e micromorfológica.

Embora houvesse recomendações indistintas para os 2 meios (2), a metodologia para avaliação de alimentos tem substituído o caldo lactose por caldo lauril sulfato-triptose $(7,19,52,88,106,118)$, tendo em vista mai or sensibilidade no aspecto do enriquecimento seletivo $(35,123)$. Porém as ültimas edições da Farmacopéia Americana (208) e da Británica (34), ainda recomendam o caldo lactose para enriquecimento, na pesquisa de Escherichia coli.

Na análise de medicamentos não estéreis e de drogas vegetais, o caldo lactose-bile-verde brilhante é utilizado, no enriquecimento seleti vo, com vistas à pesquisa de enterobactērias, de coliformes fecais e de EScherichia coli $(53,110)$, inclusive na sua quantificação $(170)$. Segundo Ro mond $(170)$, esse caldo apresenta alguns inconvenientes, uma vez que não de tecta o crescimento de coliformes anaerógenos, assim como dá resultado fal so-positivo. Dessa forma, microorganismos como Bacillus polymyxa e Bacillus macerans, produtores de gäs, desenvolvem-se em caldo lactose-bile-verde brilhante. Amostras contaminadas por leveduras, igualmente, irão acusar formação de gás carbōnico. Segundo Desvignes e colaboradores (53) alguns cocos Gram-positivos iräo desenvolver-se em função do tempo de incubação ser maior que 24 horas, embora os métodos oficiais recomendem de 24 a 48 horas, seja a $30^{\circ} \mathrm{C}, 35^{\circ} \mathrm{C}$ ou $35-37^{\circ} \mathrm{C}(2,7,52,53,88,123)$.

A questão da temperatura de incubação é bastante controvertida com relação ao caldo EC, quando da determinação e detecção de coliformes fecais. A constatação de Leitão e colaboradores (106) usando $44,5^{\circ} \mathrm{C}$ levou a resultados falso-positivos, sendo 3 vezes superiores aos observados quan do da incubação a $45,5^{\circ} \mathrm{C}$. Outros métodos recomendam, apesar disto, tempera tura como $44,5 \pm 0,2^{\circ} \mathrm{C}(2,19,118,123)$ em oposição a $45,50 \pm 0,05^{\circ} \mathrm{C}(7,52)$. 
Com relação aos resultados deste estudo, conforme os dados das Tabelas VII e XI (pg. 57 e 60), a incidencia de 5 lotes contaminados por Escherichia coli pode até ter sido em função da temperatura do banho, uma vez que a precisão do termostato empregado pode ter amplitude de sensibili dade aquén da desejāvel. Por outro lado, tendo em vista a prova confirmató ria no ágar eosina-azul de metileno, as dúvidas teriam sido eliminadas.

A inclusão deste meio com a finalidade de isolamento seletivo e identificação de Escherichia coli è assunto iguaimente variävel en função de autores e métodos. Pode ser a $35^{\circ} \mathrm{C}$ por $24 \pm 2$ horas $(7,118), 35 \pm 0,5^{\circ} \mathrm{C}$ por $24 \pm 2$ horas $(2), 35^{\circ} \mathrm{C}$ por 18 a 24 horas $(52), 35^{\circ} \mathrm{C}$ por 24 horas (88) ou $37^{\circ} \mathrm{C}$ por 48 horas $(146)$.

Há críticas ao uso desse meio, pois certos biōtipos de Escheri chia coli não produzem colónias tipicas com brilho verde (118). Aqueles mi croorganismos fermentadores lentos de lactose, assim como os lactose-negativos, produzem colōnias incolores. As limitações são de natureza física e subjetiva, sendo discutivel a capacidade do meio em detectar uma colónia distinta entre värias além daquela de distinguir especificamente uma colônia de Escherichia coli entre värias outras de coliformes.

Na metodologia apresentada por Mehlman e colaboradores (117), para a recuperação e identificação de Escherichia colì, os autores recomen daram o uso de ágar eosina-azul de metileno para o isolamento de microorga nismos fermentadores rápidos de lactose, tendo preferido para os não fer mentadores ou fermentadores lentos o uso de ágar Mac Conkey.

Na triagem das amostras, na fase de isolamento seletivo em àgar eosina-azul de metileno, foram consideradas positivas aquelas que apre sentaram colónias tipicas, isto é, pretas nucleadas com ou sem britho verde metálico $(2,52,177)$, o que pode ter excluído casos contaminados por fermen tadores lentos. Porém, não se observou a presença de colónias atipicas de Escherichia coli, isto é, rosas, opacas, anucleadas ou mucöides (2). Ainda 
para a confirmação das características anteriores foram efetuadas outras provas bioquímicas e a micromorfologia.

A pesquisa de Escherichia coli configurou, pela primeira vez, na monografia de gelatina, na USP XII (199), cuja metodologia foi sendo aprimorada cada vez mais. Se nesta época a prova era baseada em enriqueci mento não seletivo seguido de isolamento seletivo em ägar Endo ou àgar eosina-azul de metileno, para afirmar "evidéncia positiva da presença de Escherichia coli" em função das colönias típicas, em outras edições foram sendo aprimoradas com introdução de mais testes. Por outro lado, em função da sensibilidade inerente à técnica analítica recomendada, houve épocas em que o teste teve denominação diferente como sendo para identificação da presença de coliformes. Pode-se dizer que segurança maior foi introduzida a partir da 18 edição (204), onde, para teste de Escherichia coli foi exi gido o isolamento seletivo sequencial, passando do ägar Mac Conkey para ágar eosina-azul de metileno, seguido de provas confirmatórias bioquimicas e de cultura.

Alguma variação que configura no método farmacopèico británico introduzido a partir de 1973 (32) é que recomenda o enriquecimento não seletivo (caldo Mac Conkey) voltado para os termotolerantes $\left(43-45^{\circ} \mathrm{C}\right.$ ). Após isolamento seletivo em àgar Mac Conkey e confirmação pelas provas de indol a $44 \pm 0,5^{\circ} \mathrm{C}$, produção de gás e micromorfologia, a amostra é considerada positiva para a presença de Escherichia coli.

Como os métodos oficiais europeus $(34,133,134)$ exigem condições de incubação dando seletividade para os termotolerantes, cortez e colabora dores (49) analisaram plantas medicinais segundo essas recomendações.

Com relação às reaçōes bioquímicas complementares para a identificação de Escherichia coli, a prova "IMViC" cujo resultado é do tipo + + - - indica presença de Escherichia coli tipica enquanto que - + - -, as atipicas $(7,105,106,123)$. 
Procedimento analítico criticável foi adotado por Pedersen e Szabo (146), pois, esses inocularam a amostra diluída ou não, na superfície do ágar eosina-azul de metileno, e apenas desta forma efetuaram a determinação da carga de Escherichia coli em medicamentos não estéreis.

No presente trabalho, a quantificação de Escherichia coli foi em amostras que se apresentaram positivas após a triagem das mesmas.

0 resultado encontrado a partir do caldo lactose foi considera do como para Escherichia coli tendo em vista as provas bioquimicas e identificação macro e micromorfológicas executadas na pesquisa deste microorga nismo, tendo usado igual tomada de ensaio e caldo EC para a determinação do NMP por grama de produto.

Na análise com vistas a Salmonella sp. o aspecto semi-quantita tivo, comumente, é o de maior interesse $(34,47,70,133,159,170)$. A tomada $\underline{i}$ nicial representou a metade daquela recomendada pelos métodos oficiais tendo en vista a escassez da amostra.

0 enriquecimento inicial não seletivo considerou = a provável presença do microorganismo na forma debilitada e em nümero reduzido, em funçào dos tratamentos a que se submeteram as amostras durante sua produção. Objetivou o fornecimento de nutrientes necessärios e favoráveis ao desenvolvimento preferencial de salmonelas, bem como o reparo das células lesadas e reidratação (160). Para isso, empregou-se o caldo lactose, conforme recomendação oficial $(7,19,34,47,88,133,160,208)$, embora seja também usual o uso de caldo nutriente $(32,33,160)$, àgua peptonada tamponada e de caldo caseina-soja (160).

As condições de incubação, geralmente, variam de 30 a $37^{\circ} \mathrm{C}$, por 5 a 48 horas $(7,19,32,33,34,47,88,133,160)$, embora uma incubação prévia à temperatura ambiente, por 4 horas (160) promova maior recuperação do microorganismo, constituindo, inclusive, orientação da Farmacopēia Britânica de edições anteriores $(32,33)$. No entanto, em caso de suspeita da 
presença de Pseudomonas, Romond (170) alertou para o fato de que a incubação deve ser curta, visto que, os metabólitos podem ser tóxicos para as salmonelas. Porém, segundo Poelma e colaboradores (160) a incubação de 6 horas pode levar à ocorrência de falso-negativos o que se contrapõe a recomendações oficiais de 5 horas $(34,47,133)$.

A transferēncia de aliquota de $1 \mathrm{~mL}$ correspondente a $0,1 \mathrm{~g}$ de produto a partir do caldo lactose para aqueles de enriquecimento seletivo $(10 \mathrm{~mL})$ foi conforme orientação da Farmacopéia Americana XXII (208), porém a sub-cuitura de volumes menores $(0,1 \mathrm{~mL}$ ) ou maiores (de 2 a $10 \mathrm{~mL}$ ) não al tera significativamente a sensibilidade do método (160).

O emprego simultáneo dos caldos tetrationato e selenito-cistina è o mais frequente $(7,19,34,88,160,208)$, embora a FIP (47) tenha recomendado apenas o primeiro e, Romond (170), o segundo por ser menos agressivo ao microorganismo.

Apesar de a incubação ser usualmente a $30-37^{\circ} \mathrm{C}$, por 12 a 24 horas $(7,47,208)$, o emprego de temperaturas elevadas $\left(42-43^{\circ} \mathrm{C}\right.$ por 24 horas) tambèm è viável $(34,133)$, a fim de aumentar a seletividade do meio, porém há relatos (160) de que o caldo tetrationato com incubação nessas condiçóes é letal para salmonelas, bem como de que o meio de selenito incu bado a $37^{\circ} \mathrm{C}$ possibilita melhor recuperação do que a $43^{\circ} \mathrm{C}$.

No isolamento de salmonelas o emprego de pelo menos 2 meios se letivos solidas ções (160). Desta forma, a escolha recaiu naqueles mais usados, isto é, gar verde brithante $(34,70,88,160)$ e àgar sulfito de bismuto $(7,160)$. Havendo, ainda, o possibilidade do emprego de ägar citrato-desoxicolato (34, $47,133,170)$, ägar xilose-lisina-desoxicolato $(7,34,47,133,208)$, ágar verde brilhante-vermelho fenol-lactose-sacarose $(47,133)$, SalmonellaShigella (SS) $(88,160)$, Mac Conkey (160) e àgar Hektoen $(7,160)$. 
As condições de incubação foram as usuais, isto é, a $35-37^{\circ} \mathrm{C}$, por 18 a 24 horas (160), embora exista recomendação para até 48 horas para o sulfito de bismuto, para afirmação segura da ausencia de colónias de salmonela (144).

Verificou-se a presença de colonias suspeitas com as seguin tes características: rosas, opacas, pequenas, em meio de ágar verde briThante $(34,208)$, diferentemente daquelas transparentes e brancas opacas, rodeadas ou não por halo avermelhado ou róseo.

No meio de àgar sulfito de bismuto, considerou-se positiva a presença de colöni as pretas ou esverdeadas (208) e, igualmente daquelas com coloração marrom $(7)$.

A utilização de meios diferenciais de àgar ferro-triplice açücar $(7,34,47,70,88,133,160,208)$ e de ágar ferro-lisina $(7,160)$ visou, em ambos casos, a verificação da formação de sulfeto de hidrogénio e, respectivamente, da utilização de glicose, lactose e sacarose e da descarboxilaf̧ão da lisina (160).

0 ägar ferro-tríplice açúcar pode ser incubado a $30-37^{\circ} \mathrm{C}$ por 18 a 48 horas $(7,34,70,160,208)$, tendo-se adotado a temperatura de $36 \pm$ $1{ }^{\circ} \mathrm{C}$ por 24 horas $(7,34,70,160)$ diferentemente do àgar ferro-1isina por 48 horas $(7,160)$.

Verificou-se a presença de colónicas tipicas de salmonelas em àgar ferro-trīplice açúcar, tendo levado à formação de coloração vermelha na superficie inclinada e, amarela, na base, indicando, respectivamente, reação alcalina e ácida, além da ocorrēncia de produção de gás acompanhada da formação de sulfeto de hidrogénio (133).

Diferentemente, no meio de ágar ferro-lisina não se constatou a presença de colónias tipicas, isto é, produtoras de reação alcalina na base do meio de cultura (fundo), levando à formação de coloração púrpura 
(violeta) $(7,160)$, bem como à produçāo de sulfeto de hidrogénio, indicada pelo escurecimento do àgar. Nestes casos, a AOAC (7) recomenda que não se descartem as colónias positivas no primeiro meio, a fim de efetuar testes bioquímicos adicionais e sorológicos.

Na anàlise de medicamentos è usual o emprego unicamente de àgar ferro-tríplice açúcar $(34,133,208)$. A USP XXII (208) considera "de aacordo com os requisitos para ausēncia do gênero Salmonella sp.", as amostras que apresentam reação negativa nesse meio, com possibilidade de "evidências confirmatórias adicionais, se necessärio".

Outros métodos oficiais $(34,47,133)$ sugerem a confirmação mais precisa dos resultados, normesme através da realização de "testes bio químicos e sorológicos".

Portanto, tendo em vista os testes realizados até a etapa de reações bioquimicas preliminares, pode-se concluir, apenas, pela suspeita da presença do microorganismo nas 5 àmostras que acusaram provas positivas (Tabelas VII e XV) (pg.57 e 64).

\section{4 Resultados de contaminação microbiana}

Conforme os dados das Tabelas IV, V e VI (pg. 54,55 e 56), a incidéncia de carga contaminante viável é elevada, pois, quando se conside ra o valor de $10 \%$ g como sendo o limite para carga bacteriana, 59 dentre 84 lotes estão acima deste valor. Embora, a contaminação fúngica (Tabela VI) (pg. 56) tenha indicado qualidade melhor, os dados referentes aos esporos (Tabela V) (pg. 55) refletem situação semelhante ao da contagem bacteriana total, apresentando certa correlação. Pela frequéncia de distribuição dos lotes, percebe-se que 60 estão entre $10^{2}$ a $10^{6}$ (Tabela IV) (pg. 54) em relação à carga bacteriana, cujo resultado se assemelha aos encontrados por outros autores $(9,49,55,59,62,110,131,147,177)$. 
Este resultado pode ser em decorrēncia do uso de drogas brutas sem devido cuidado no preparo de fitoterápicos e/ou a ocorréncia de recontaminações durante sucessivas operações de colheita, armazenamento, mondagem, acondicionamento e outras manipulações atè a transformação em esper,ia lidade farmacêutica.

As plantas medicinais, como qualquer outro vegetal, estão sujeitas aos mesmos veículos de contaminação microbiológica, isto é, solo, ar e água, apresentando, portanto, microflora rica e variada, refletindo as condições ecolögicas $(9,110)$. Além disso, vários fatores influem na qua lidade microbiana final como a natureza do produto fresco, intervalo de tempo entre a estabilização e o processo de secagem, tempo e temperatura de secagem, umidade do produto acabado, condições nigieñicas do local de trabalho, caracteristicas intrinsecas do produto, tipo de embalagem, conservação etc.

Sabe-se que a secagem da droga ou do granulado para comprimidos pode eliminar a maioria dos microorganismos inicialmente presentes na droga e mesmo a etapa de compressão, que propicia a redução da população microbiana em função da força aplicada $(9,21,59,62,78,158,159,177)$. Assim, no caso de levedura de cerveja, apesar do alto teor de vitamina B favorecer o crescimento microbiano (120), 7 dos 11 lotes analisados (Tabelas XVII, XVIII, XIX, XX e XXI) (pg.66,67,68,69 e 70) apresentaram carga bacte riana baixa, o que pode ter sido em função do processo produtivo, uma vez que coincidentemente se trata de amostras sob a forma de comprimidos.

0 contato direto do vegetal com o solo é fator predisponente à ocorrência de altas cargas contaminantes (187), porēm, avaliando a qualida de microbiológica de plantas medicinais ou de suas partes, muitos pesquisa dores chegaram à conclusão de que não havia relação entre a carga contaminante viävel e a parte vegetal considerada $(9,49,114,131)$. Em contraste, Kedzia e Holderna (95) apontaram os frutos, sementes e cascas como partes 
contendo menor carga bacteriana e füngica quando comparadas a folhas, f10res, rizomas e o vegetal todo. Da mesma forma, Diding e colaboradores (59) verificaram a contaminação alta em föihas e rajizes. Negretti (131) detectou microorganismos patogênicos mais frequentemente em raizes, rizomas, cascas e folhas, comparativamente aos frutos e à planta considerada no todo. Aureli e colaboradores (9) porém, preferiram atribuir a alta contamina ção ao ambiente e à tecnologia de produção ao invés da porção vegetal.

Essas constatações não podem ser comparadas às amostras analisadas neste trabalho, pois, os diferentes órgãos vegetais sofreram muitos processos atē a apresentação farmacéutica final. Logo, pode ter havido redução na carga contaminante originalmente presente no vegetal ou recontami nação em função de condições sanitärias impröprias à manipulação farmacéutica.

Quando o nivel de contaminação é muito baixo, essa carga pode representar os sobreviventes de uma população que já tenha causado decompo sição do substrato (183). Por outro lado, elevado nivel de contaminantes pode significar falha no processo de descontaminação ou mesmo omissão de tratamento, além da possibilidade de multiplicação de microorganismos, entre outros, os patogénicos. Em decorrência disto, a deterioração do produto passa a ser aspecto preocupante, uma vez que compromete a eficácia tera pẽutica.

A presença de esporos bacterianos aeróbios mesófilos apresentando estreita correlação com a carga bacteriana total pode serreflexo do pröprio processamento, cujas condições permitiriam a sobrevivēncia e perma néncia dos contaminantes na sua forma de resisténcia. Esses esporos são ge ralmente do gènero Bacillus, Gram-positivos e muito frequentes em medicamentos sólidos de uso oral $(6,54,183,194)$. Entretanto, sua origem pode estar intimamente ligada à contaminação ou veiculação através da poeira (110). De acordo com os dados da Tabela $V$ (pg. 55), 38 lotes apresentaram carga de esporos igual ou acima de $10^{4} / \mathrm{g}$, niveis estes comprometendo amostras constituídas 
de folha, rizoma, raiz, semente e vegetal inteiro. A frequencia elevada destes contaminantes em amostras de guaraná $(81,5 \%)$ pode ser atribuida à contaminação durante o processo de colheita, lavagem, mondagem, secagem e/ ou permanéncia seletiva dos esporos no decorrer dos diferentes estágios pro dutivos. Com relação às demais amostras contendo outras partes vegetais, pouco pode ser comentado em função da amostragem restrita.

Neste trabalho, segundo os dados da Tabelas IV e V (pg. 54 e 55), os 14 lotes de guaraná que apresentaram carga viável bacteriana total acima ou igual a $10^{5} / \mathrm{g}$ tarbém acusaram contaninação por esporos. Com relação a esta droga, a má qualidade independe do produtor, pois pelos dados das Tabe las XVII, XVIII, XIX, XX e XXI (pg. 66,67,68,69 e 70), 13 produtoresdentre 14 apresentaram resultadosinadequados, o que pode sugerir condiçōes imprö prias devidas à natureza da matéria-prima. Se isto for realidade, significa que muitos fabricantes não dispõem de controle de qualidade na sua empresa, pois não selecionam os fornecedores da semente de guaranä, nem sequer controlam os seus produtos em diferentes fases da manipulação farmacêutica. Este fato está bastante evidente nos produtores B e L (Tabelas XVIII e XIX) (pg. 67 e 68). No primeiro, além de 2 lotes de guaraná, alcachofra, centelha, espinheira santa, espirulina e ginseng, tamoèm, apresentam 1 ou 2 lotes com carga viävel total acima de $10^{5} / \mathrm{g}$. Situação semelhante ocorreu, também, com o produtor $L$, embora não tenha sido exatamente com produtos contendo a mesma droga vegetal.

Por outro lado, quando o nümero de esporos foi maior que da contagem bacteriana total, pode-se deduzir que o choque térmico está sendo necessário para o desencadeamento da germinação dos esporos, ainda que o método de contagem tenha sido em meio líquido.

Com relação às amostras que apresentaram contaminação bacteria na total baixa, houve também coincidéncia com relação à carga de esporos 
(Tabelas IV e V) (pg. 54 e 55). Estas foram representadas por confrei, leci tina de soja, öleo de germe de trigo e zedoária. Como a amostragem destas não pôde ser com maior número de lotes, quando se refere a confrei e zedoá ria, poucas referéncias podem ser feitas quanto à origem vegetal, produtor ou parte utilizada e a qualidade microbiana final. Quanto aos produtos de rivados, evidentemente, que é compreensivel a razão pela qual o nivel de contaminação è baixo.

Quanto ao total da amostragem, niveis iguais ou maiores que $10 \%$ g foram constatados em 23 lotes, coincidindo, igualmente, com as espécies vegetais contendo carga bacteriana semethante. Referem-se a alcacho fra, centelha asiática, espinheira santa, espirulina, ginseng brasileiro e guaraná.

Analisando os dados da Tiabela VI (pg. 56), as amostras com car ga füngica elevada (maior ou igual a $10^{5} / \mathrm{g}$ ) foram em menor nümero (apenas 2 lotes) quando comparado à contaminação bacteriana, enquanto que 55 dentre 84 lotes apresentaram nivel inferior a $10^{2} / \mathrm{g}$. Com relação às amostras de guarană, verificou-se, igualmente, para este requisito, qualidade. inadequada, tendo apresentado $55,6 \%(15 / 27)$ dos lotes com carga fúngica superior a $10^{4} \mathrm{~g}$. Confrontando-se este resultado com aquele encontrado por Lutomsky e Kedzia (114), pode-se dizer que a qualidade destes fitoteräpi $\cos$, no tocante à contaminação fúngica, è superior ao da amostragem feita por aqueles autores. Os mesmos encontraram apenas 10\% das drogas vegetais brutas com carga inferior a $10^{2} / \mathrm{g}$.

A contaminação füngica não foi submetida à identificação; entretanto, segundo trabalho de outros pesquisadores, há predomináncia de Aspergillus niger e Penicillum $(86,114,171)$. Igualmente, não houve preocupação quanto à presença de bolores ou leveduras, mais foi possivel perce ber que a frequéncia de leveduras foi muito inferior em relação à débolores (Tabela XII) (pg. 61). Pode-se atribuir tal ocorrencia à provável falha me- 
todológica, sendo inibidas pelo antibiótico acrescido ao meio de Sabourauddextrose.

Segundo Devleeschouwer e Dony (55), que empregaram o meio reco mendado pela FIP (47), contendo 2 antibiöticos, ocorreu fato semelhante, re cuperando leveduras em número reduzido de amostras, mesmo adaptando as con dições de incubação.

Em função da carga fúngica, o risco relacionado à presença de aflatoxinas em drogas vegetais foi objeto de estudo de diversos pesquisado res, embora os resultados tivessem sido variáveis $(86,114,171)$. Tal variação foi atribuīda a fatores que influenciam sua produção como caracteristị cas da carga genética do hospedeiro, dispersão do inóculo de esporos por vetores, estresse da umidade e a presença de outros contaminantes fúngicos invasores.

Neste trabalho, como não se determinou a presença de aflatoxinas, mesmo nas amostras mais contaminadas por bolores, não se pode avaliar o risco, mas há indicação da condição inadequada de conservação. Segundo o limite estabelecido pela OMS, o produto com nivel de aflatoxina maior que $20 \mathrm{ug} / \mathrm{Kg}$ deve ser rejeitado (171).

Com relação à pesquisa de Escherichia colí, os dados da Tabela VII (pg. 57) indicam elevada incidencia de coliformes fecais nestas amostras. Ao se fazer correlação entre a contagem total bacteriana e a presença de coliformes totais pode-se dizer que quando a carga é de $10^{4}$ a $10^{6} / \mathrm{g}$, há intima relação com a contaminação por coliformes (Tabela XIII) (pg. 62). Portanto, pelo raciocinio inverso e também confirmado pelos dados das Tabe las VII, XVII, XVIII, XX e XXI (pg. 57,66,67,69 e 70), amostras de confrei, lecitina de soja, óleo de germe de trigo e zedoária apresentam qualidade satisfatöria em todos os aspectos.

Da mesma forma, a correlação entre coliformes totais e carga de esporos também é verdadeira (Tabela XIV) (pg. 63), pois não houve 
contaminação por coliformes totais quando o nivel de esporos era inferior a $10 / 9$.

Logo, amostras mais contaminadas, seja por esporos ou não, geralmente continham coliformes, diferentemente da presença de fungos (Tabela XV) (pg. 64). Constatação semelhante foi efetuada por Diding e colabora dores (59), pois os coliformes foram encontrados em amostras com carga bac teriana de $10^{4}$ a $10^{6} / 9$.

A presença de coliformes fecais foi detectada em 13 lotes, nos quais a contaminação bacteriana total havia acusado cargas compreendidas en tre $10^{3}$ e $10^{10} / \mathrm{g}$ (Tabela XIII) (pg. 62). Estes, por sua vez, estavam, também, com fungos (Tabela XV) (pg. 64). Isto permite deduzir que estas amostras são de qualidade inadequada, indicando condiçóes sanitärias impróprias do produtor para a manufatura e comercialização destes produtos.

Portanto, segundo os dados da Tabela VII (pg. 57), nesta amostragem com 84 lotes, 5 acusaram Escherichia coli (centelha asiática, espirulina, ginseng brasileiro, guaraná e levedura de cerveja).

Em vista deste resultado indicando qualidade impropria para me dicamentos, as 5 amostras foram reanalisadas com vistas à quantificação deste indicador da contaminação fecal. A presença de Escherichia coli é ainda mais preocupante quando se consideram os dados de contagem dos conta minantes viāveis totais para estas amostras (Tabela XVI) (pg. 65). Assim, por exemplo, o lote de centelha asiática apresentou niveis altos de contaminação em todos os aspectos com $5 \times 10^{9}$ bactérias, $2,6 \times 10^{4}$ esporos bacterianos, $1,7 \times 10^{4}$ fungos e $1,5 \times 10^{2} \underline{E}$. coli por grama. Outros três $10-$ tes contendo o mesmo microorganismo mostraram-se especialmente contamina dos. Estes apresentaram em sua composição guaranā, ginseng brasileiro e es pirulina. Para estes a carga bacteriana variou de $10^{5}$ a $10^{8} / \mathrm{g}$, a de esporos, de $10^{4}$ a $10^{6} / \mathrm{g}$, a contagem de fungos esteve igualmente elevada, tendo alcançado até $10^{4} / \mathrm{g}$ e aquela de Escherichia coli variou de 2,3 a $9,3 \times 10 / \mathrm{g}$. 
Estes dados são alarmantes, uma vez que se tratam de medicamentos. 0 lote de levedura de cerveja apresentou niveis inferiores, porém, ainda assim a con tagem bacteriana superou $10^{3} / \mathrm{g}$ e a füngica, $10^{2} / \mathrm{g}$. Estes resultados, além de colocarem em risco a saúde do paciente, podem acarretar diminuição ou perda de atividade terapéutica, uma vez que indicam ou podem levar à degradação do princípio ativo.

Desta forma, tendo en vista o estado de "stress" e depressão $\underline{e}$ xistente no paciente que busca propriedades terapéuticas do guaranä, pode enfrentar problemas decorrentes da instalação de infecção por microorganis mos oportunistas, igualmente para o consumidor de ginseng, geralmente apre sentando quadro de esgotamento físico e ou mental. 0 emprego de medicamento a base de espirulina, com tal nivel de contaminação, pode não ser justi ficável para pacientes submetidos ao regime alimentar de emagrecimento 151 , 63,1921 .

Como estes 5 lotes, apesar de não serem da mesma espécie botânica, são comercializados pelo mesmo produtor (B), este fato permite concluir que as conơições sanitärias da fábrica são imprōprias para manufatura de medicamentos, além de indicar que não há controle de qualidade, mesmo a níver de qualidade de matérias-primas.

Lotes da mesma droga vegetal fabricados por outros produtores não acusaram a presença de Escherichia coli, embora apresentando altas con tagens. Portanto, mesmo para outras 8 amostras que apresentaram coliformes fecais, apesar de não ter sido isolada Escherichía coli, o aspecto da qualidade microbiana pode representar risco à saúde do consumidor. Neste caso são 6 os fabricantes implicados ( $A, B, C, E, H$ e L), conforme a Tabela XVI(pg. $65)$, os quais, exceto $E$, participaram nesta amostragem com relativa representatividade. Este aspecto passa a ser preocupante quando se atenta para distribuição dos mesmos lotes para grande parcela do mercado.

$$
\text { Mesmo considerando o total de } 13 \text { amostras contendo coliformes }
$$

fecais, o produtorb se destaca pela maior rejeição, tendo sido 7 em 26 lotes. 
Quando se incrimina o produtor B em função da condição sanitäria inadequada através dos 5 lotes de produtos de onde foi isolada Escheri chia coli, não significa que o restante das amostras esteja em perfeitas condiçōes, pois, pode-se admitir que a contaminação fecal tenha ocorrido, mas ter sido eliminada em função de processo térmico aplicado ao material, em algum estägio da manipulação.

Ao admitir que o processo térmico aplicado durante a fabrica ção pode ter eliminado o contaminante fecal, os 5 lotes incriminados devem ter sido em consequéncia da má qualidade da matéria-prima, uma vez que se tratavam de 3 lotes de cápsulas e 2 de pó. 0 fornecedor da droga bruta poderia ser o primeiro responsável, porém, torna-se evidente que não foi aplicado tratamento descontaminante algum pelo fato de não ter sido analisa da, quando da compra desta matéria-prima. Por não ter dado analítico, uma vez que o produtor não deve dispor de serviço de controle de qualidade, não houve sequer preocupação para a aplicação de algum processo descontaminante. Logo, é admissivel que a presença de Escherichia coli tenha ocorrido desde a fase de droga bruta, não sendo recontaminação pós-processamento.

Devleeschouwer e Dony (55) isolaram o microorganismo de amostras de drogas vegetais contendo contaminação bacteriana da ordem de $10^{4}$ a $10^{6} / \mathrm{g}$ e $10^{3}$ a $10^{5} / \mathrm{g}$ de fungos. Iguaimente, Lenoble e colaboradores (110) a presentaram resultados relacionados a $10^{6}$ e $10^{5} / \mathrm{g}$, respectivamente, de bac térias totais e fungos.

Outros microorganismos como estreptococos fecais e clostrídios sulfito-redutores podem revelar a presença de contaminantes da flora fecal. Em alguns pontos da Europa, o Clostridium perfringens é considerado como indicador de contaminação fecal (18). Lenoble e colaboradores (110), por exemplo, consideram indicação de contaminação fecal somente quando estão presentes, além das 2 espécies anteriormente referidas, os estreptococos fecais, sendo que das 12 amostras de Mentha piperita analisadas pelos auto res, 7 apresentaram sinais de contaminação fecal animal ou humana e destas, 
5 acusaram presença de Escherichia coli. Semelhantemente, Cortez e colaboradores (49) isolaramclostrídios e estreptococos fecais, além de Escheri chia coli, em 4 dos 79 lotes de plantas medicinais amostrados.

O significado desses microorganismos è variável de acordo com - tipo de produto. Assim, conforme mencionado anteriormente, quando esse passa por algum tratamento térmico, a Escherichia coli termolábil não sobreviveria (120). Nesse caso, estreptococos fecais e clostrídios evidencia riam, satisfatoriamente, contaminação de origem fecal em consequéncia de sua maior resistência a temperaturas relativamente altas $(14,120)$ e ao meio externo (110), do que Escherichia coli. Por outro lado, os esporos de Clostridium perfringens, por exemplo, sobreviven a condiçōes drästicas (14) e são responsáveis pela ampla distribuição da bactéria, o que possibilita seu isolamento dos mais variados ambientes como àgua, solo, poeira, trato intestinal, fezes, àrea de produção farmacéutica (14), plantas medicinais $(49,110,131)$ e aromáticas $(9)$.

Desta forma, pesquisadores americanos consideram a bactéria sem validade para a indexação da contaminação fecal (18), tendo em vista igual mente que os esporos foram isolados em zonas polares destituidas de vida $\underline{a}$ nimal e humana (110).

Portanto, a presença de Clostridium perfringens pode ser relacionada às condições higiènicas insatisfatörias de produção, oferecendo risco potencial à saúde, pelo menos, no que se refere à produção de espo ros no produto contendo a droga vegetal contaminada (9).

Na anälise de plantas aromáticas que passaram por processamento (150), a avaliação da qualidade microbiológica è semelhante àquela realizada no presente estudo, isto é, efetua-se a contagem de aeróbios, de fungos e a pesquisa de coliformes. No caso da presença destes últimos, pro cede-se à sua determinação. A pesquisa de salmonelas e shigelas è feita apenas quando o armazenamento foi feito em condições inadequadas. 
Salmonella sp. é, também, outro indicador das condições impróprias de faobricação de medicamentos, atém de que pode ocorrer desde a fase de cultivo das plantas, principalmente, devido à irrigação, bem como manuseio, armazenamento e transporte (107). A eliminação dessa bactéria pela a ção biocida química inerente à caracteristica da planta refere-se às espé cies aromáticas, pois, o óleo essencial apresenta ação antimicrobiana $(9$, 150).

0 isolamento de salmonelas defronta-se com problemas de ordem analitica, pois, sua recuperação sofre, por vezes, problemas de competição com a microflora natural e numericamente elevada (107).

Neste estudo, no isolamento de salmonelas, não foram feitas provas bioquimicas completas, bem como as sorológicas, conforme exposto an teriormente. Contudo, pelos dados das Tabelas XIII, XIV e XV (pg. 62,63 e 64), pode-se dizer que a suspeita da sua presença está intimamente relacio nada com o isolamento de Escherichia coli.

Associa-se, geraimente, o problema de contaminação microbiana às formas farmacéuticas 1 íquidas $(130,139)$, tendo em vista a alta atividade de àgua favorável ao desenvolvimento microbiano. Porém, as formas farma céuticas sōlidas sào igualmente passiveis de contaminação, tendo sido consideradas e estudadas por vários autores $(6,40,53,73,101,120,184,211)$. Waterman e colaboradores (211), por exemplo, arrolaram os fatores que influem na sobrevivenncia de microorganismos em formas farmacêuticas sólidas, a lém de outros como condiçóes ambientais de umidade, temperatura, ausencia ou presença de oxigènio e tempo de armazenamento.

Conforme os dados da Tabela VIII (pg.58), a carga bacteriana total foi marcadamente elevada em amostras constituīdas de pó, seguidas de cápsula e comprimido.

A carga bacteriana atingiu niveis da ordem de $10^{9}, 10^{7}$ e $10^{6} / \mathrm{g}$, 
respectivamente, em cápsulas, comprimidos e pós, cujos valores se assemeTham aos resultados encontrados por Dony (62) em formas sölidas como drá geas, granulados, além daquelas analisadas neste estudo. Verificou contagens bacterianas superiores a $10^{2} / \mathrm{g}$, tendo alcançado até $10^{9} / \mathrm{g}$ nas amostras contendo matérias-primas vegetais e animais, tendo constatado a presença de enterobactērias, estreptococos fecais e fungos.

Ainda, analisando os dados da Tabela VIII (pg.58), niveis de contaminação bacteriana superiores a $10^{3} / \mathrm{g}$ foram encontrados em $66,7 \%$ e $57,2 \%$, respectivamente, de cápsulas e comprimidos. Nos pós, os dados foram particularmente elevados, abrangendo a totalidade das amostras. Além disto, $80,0 \%$ destas amostras acusaram cargas superiores a $10 \%$, sendo que $33,3 \%$ com resultado compreendido entre $10^{5}$ e $10^{6} / \mathrm{g}$. Cabe a ressalva de que 13 dos 15 lotes de pó são de guaraná e como este é recomendado pelo produtor como complemento dietético ou alimento, conforme as informações inscritas en rótulo das embalagens, o fabricante poderia encontrar justificativa para controle menos rigoroso e consequentemente este perfil analitico.

Estas observações diferem daquelas de Desvignes e colaborado res (53), que verificaram percentagens menores para o mesmo limite $110^{3}$ bactérias/g), tendo sido, respectivamente, de 18,5 a 13,5\% para cápsulas e comprimidos. As constatações de Arribas e colaboradores (6) foram muito di ferentes dos resultados encontrados em fitoterápicos brasileiros, pois, ape nas $11,1 \%$ dos pós e 3,0\% das cápsulas e comprimidos se enquadravam ao mes no padrão. Ainda, na amostragem nacional, cerca de $48,0 \%$ das cápsulas e comprimidos apresentaram niveis superiores a $10^{4} / \mathrm{g}$.

Na avaliação de Desvignes e colaboradores (53), a incidéncia de contagem bacteriana inferior a $10^{4} / g$ foi pröxima entre as amostras de cápsulas $(95,0 \%)$ e de comprimidos $(92,0 \%)$, porém de maior valor que na presente pesquisa. 
Pelos valores da Tabeła IX (pg. 58), a contaminação por esporos bacterianos foi alta nos pós, tendo $73,3 \%$ dos lotes acusado carga maior ou igual a $10^{3} / \mathrm{g}$ em comparação a $60,4 \%$ das cápsulas e $52,4 \%$ dos comprimidos. A manutenção da viabilidade dos esporos em comprimidos è fato comprovado por Yanagita e colaboradores (218) uma vez que são altamente resistentes à compressão, assim como o são aos vãrios agentes químicos e físicos. Entretanto, pelos dados deste estudo, onde a amostragem abrangeu diferentes produtos contendo drogas vegetais diversas, por sua vez fabricados por muitas empresas, não se pode concluir que a forma farmacêutica tenhe apresentado fatores determinantes na qualidade ricrobiana.

Ao considerar o nivel de esporos $66,7 \%$ dos pós apresentaram car ga igual ou superior a $10^{4} / \mathrm{g}$, enquanto que para cápsulas e comprimidos os valores foram de $41,7 \%$ e $38,7 \%$ respectivamente.

No levantamento feito por Arribas e colaboradores (6), a contaminação por espécies do gènero Bacillus foi maior en pós $(37,0 \%)$, seguido de comprimidos $(30,3 \%)$ e cápsulas $(13,0 \%)$. As espécies isoladas a partir de comprimidos forer Bacillus subtilis, Bacillus brevis e Bacillus licheniformis, en quanto que Bacillus pumilus e Bacillus polymyxa, de pós e Bacillus subtilis e Bacillus brevis, de cápsulas.

Semelhantemente aos valores de contagens bacterianas, houve gran de variação naqueles de esporulados encontrados nas 3 formas iármacêuticas, tendo-se constatado cargas de ate $10^{8}, 10^{6}$ e $10^{7}$ esporos/g, respectivamente, en cápsulas, comprimidos e pós (Tabela IX) (pg. 58).

No que se refere à carga füngica, conforme a Tabela $x$ (pg. 59), nenhuma am̃ostra de pó acusou menos de $10 / \mathrm{g}$, contrariamente à grande incidencia deste nivel nas outras formas estudadas, que foi maior em comprimidos $(80,9 \%)$ do que en cápsulas $(50,0 \%)$. Além disto, à maioria dos lotes correspondentes a estas últimas $164,6 \%$ das cápsulas e $90,4 \%$ dos comprimi- 
dos) apresentou menos de $10^{2}$ fungos/g en contraste com apenas $33,3 \%$ dos pós. Quando presente a contaminação fúngica, sempre houve predomināncia de bolores, nas 3 formas farmacéuticas (Tabela. XII) (pg. 61). As leveduras não foran isoladas de comprimidos. Este fato pode encontrar explicação no processo de fabricação dos mesmos, corn a redução do teor de umidade do produto en função da etapa de secagem do granulado ou da compactação pela compressão to mesmo, criando assin condição desfavorävel $(21,158,159)$. 0 aparecimento de ambos os contaninantes fünicos foi verificado em 3 lotes (Tabelas XVIII e XXI) (pg. 67 e 70), sendo 1 de ginseng coreano (cápsula, pro Gutor E), I de levedura de cerveja $(p o ́$, produtor $B$ ) e outro de guaraná (pó, produtor S). O lote de guaraná apresentou nivel especialmente elevado de ambos os contaminantes fúngicos sendo die $2,3 \times 10^{3}$ jolores/g e $7,5 \times 10^{3}$ leveduras/g (Tabela XXI) (pg. 70). o lote r: $:$ levedura de cerveja estava particularmente contaminado, tendo apresentado inclusive contarinação por Escherichia coli e contagem de bolores superior à de leveduras $(7,5 \times 10 / \mathrm{g})$, diferentemente daquele de ginseng coreano, contendo coliformes fecâis, porén com carga ce leveduras $\left(1,5 \times 10^{2} / \mathrm{g}\right)$ superior à de bolores $(4,3 \times 10 / \mathrm{g})$ (Tabela XVI) (Fg. 65). A presença de levedurâ, isoladanente, ocorreu era 2 amostras de càpsulas (Tabela XI1) (pg.61).

As conáições necessärias ào desenvolvimento destes microorga nismos, incluindo a umidade, poden ter sido fornecidas na fase produtiva ou de armazenamento, en função da umidade relativa e temperatura, durante estas etapas, havendo, ainda, que considerar as propriedades físicas inerentes às pröprias drogas, como característica higroscópica. Desta forma, maior teor ce água livre favorece iguaimente o desenvolvinento de levećuras, cujas necessidades de água livre são pouco maiores que aouelas dos bolores (21).

Aparentemente, não hó correlação entre a presença destes micro organismos en combinação, tenco en vista o nümero reduzicio de amostras que 
acusaram a presenca de ambos.

Ainda com relação às leveduras, considerando que estas crescen. mais rapidamente do que os bolores e, frequentemente, junto deles (123) e, visto a sua baixa incidencia verificada nos fitoterápicos (Tabela XII) (pg. 81), isto pode indicar, conforme discutido anteriormente, o uso de método inadequado à sua recuperação. Pode ter ocorrido inibição de crescimento pe los antibióticos antibacterianos do meio de cultura, o que tornaria inviável o estabelecinento de relação segura entre os resultados obtidos e as formas farriacéuticas estudádas.

A contaninação por coliformes totais e fecais foi coerente en relação à contaminação total constatada nas 3 formas farmacéuticas. Assimi, conforme os dados da Tabela XT) os pós apresentaram percentagens superio res de ambos os grupos de contaminantes $(66,7 \%$ de coliformes totais, $33,3 \%$ de coliformes fecais) seguidos de cápsulas $(47,9 \%$ de coliformes totais, $14,6 \%$ de coliformes fecais) e comprimidos $(33,3 \%$ de coliformes totais e $4,8 \%$ de coliformes fecais). O mesmo verificou-se para Escherichia coli, re cuperacia a partir de pós $(13,3 \%)$ e cápsulas $(6,3 \%)$, porém, não foi isolada de comprimidos, o que era de se esperar, levando em consideração a sensibi lidade cesta espécie ao calor $(9,123)$. Todavia, con relação à compressão, estudos de Yanagita e colaboradores (218) demonstraram ser o microorganismo mais resistente do que outras bactérias com tananho celular maior.

A verificação de que as formas farnacéuticas sölidas estaven entre as mais contaminadas foi feita por värios autores $(53,191)$ que encon traran niveis iguais ou superiores a $10^{4} / \mathrm{g}$, à senelhança do que foi consta tado aqui.

As cápsulas e comprinidos apresentaran niveis relativamente al tos de contaminação, diferentemente do que outros autores verificaram $(40$, 55), o que pode ter ocorrido en função da origern essencialmente natural das drogas consituinces e, no caso cas cápsulas, tambën en decorréncia da 
qualidade das cápsulas gelatinosas como componente isolacto, visto que a ge latina è natëria-prima altamente contaminada $(77,147,194,215,216)$, devendo ser tratada adequadanente, além de que a etapa de encapsulação (77) po de ser fonte de nova contaminação. No entanto, não foi efetuada a análise em separado, visto que o produto é consumido como un todo, tendo-se, portanto, avaliado a qualidade final do mesmo. Desta forma, pode ter havido interferencia deste fator nos resultados encontrados, devendo-se considerar com cautela as conclusões relativas às espécies vegetais, quando apresentadas sob a forma de cápsulas.

Apesar de haver em abundáncia substratos como anido e lactose, Bos e colaboradores (21) atribuíram o crescimento microbiano raro em comprimidos às condições adequadas de armazenamento, isto é, em ambiente seco.

A expressão cios resultacos en microoranismos por grana de pro duto, visa, principalmente, o risco do produtor (40), porém sob o ponto de vista de risco do consunidor, una mesma dose infectante de microorganismos ten significado diferente de acordo com a via de administração, a posologia e condições do pröprio paciente. Desta forma, Desvignes e colaboradores (53) consideraram inporiante a expressão das contagens en número de riicroorganismos por unidade de apresentação farmacéutica, tendo sido adaptada por outros autores $(21,40)$.

Tendo emi vista que a elevada flora contaminante dos fitoterápi cos pode induzir à degradação dos produtos e consequente comprometimento da eficácia terapêutica, torna-se evicente a necessidade de se manter sob controle todos os fatores que influern na qualidade destes produtos, o que é possivel somente quando o producor segue as Boas Präticas de iranufatura $(4,41,77,80,112,119,161,182,207)$.

Portanto, a qualidade microbiológica deve ser comprovada duran te todia a produção, não podendo ser cbíida simplesmente por uma esteriliza 
ção final que mascara as más condições de fabricação (162).

Mesmaecker (119) enumerou pontos importantes para garantir a qualidace e eficácia das planias medicinais através da identificação de cá da espécie, ausència de contaminação por materiais estranhos, pureza micro biolögica e teor de princípios ativos. Hä estudos mostrando resultados favoráveis do desempoeirariento de plantas medicinais $(55,106,150)$.

No aspecto nicrobiológico, portanto, o cuidado $\mathrm{ccm}$ os pontos criticos do processo é essencial, devendo considerar que o nivel de microorganismos varia de acordo cori as condições de produção, método de colheita a tratamentos posteriores $(114,150)$. A limpeza e o processanento desses produtos possibilitari a redução do nîvel de contaninação, assin. cono a secagen e a moagen, esta ültima através do suposto aumento de ieriperatura. o oxido de etileno é usado em fumiaação agricola e industrial (59), em descontaminação de especiarias (150) e alimentos (59), porër. a sua ação al quilante, com propriecades mutạeñicas (5s), não o torna um agente seguro, podencio interferir com os constituintes das drogas e formar produtos tónicos. A esterilização de plantas medicinais contendo diferentes grupos de principios ativos foi estudada $(172,173)$, sencio que os resultadics for ari va riáveis quanto ao efeito sobre a atividade das mesmas.

A aplicação de radiação gama eñ plantas aromáticas de uso âlimentar é permitida, sendo regulamentaca a sua utilização no país (27), porén, para plantas medicinais, a ausencia de legislação pertinente dáa margerii para que os procutores utilizen esse recurso. Porém, o efeito da radia ção sobre os princípios ativos não está bem esclarecico, havendo necessida cle de estucos en particular, visto que nodificações na composição quínica e na própria estrutura ocorreram em outros produtos farmacêuticos $(43)$. 0 seu usc en medicamentos opoterāpicos de natureza enzimática levou à descon teminação satisfatória sem perda significativa de atividade (178). Em anti biöticos, a radiação gana afetou a atividade da penicilina $G$ e oxitetraci 
clina, diferentemente dos outros antibióticos testados por Gupta e colaboradores (79). A sua aplicação na planta de Atropa belladona foi capaz de induzir mutâções na maioria de suas características (94). Alguns mutantes apresentaram aumento no teor de alcalóides.

Portanto, a esterilização de drogas vegetais deve ser estudaca criteriosamente para cada caso, com visias a manter a integridade dos prin cipics ativos.

No que se refere a produtos naturais, a anàlise rotineira é in dicada (207). Para produtos con grande probabilidace de contaminação, Personné e colaboradores (151) consideraram a necessidade de efetuar concrole nicrobiológico sobre cada lote de fabricação.

Se por um lado è evidente a necessidade de padrões microbianos especificos para drogas vegetais com particularidades marcantes, não se pode dissociar do fato de que as especialidades fitoterápicas são medicamientos. Portanto, devem apresentar padrão de qualidade, embora não se veri fique na prätica, expondo o consumicior a grandes riscos.

Desta forma, hà contraste entre a necessidade de implantação die padrões mais tolerantes e as exigenncias de qualidãde de medicamentos não estéreis de uso oral, por considerar a origem natural dos insurnos fitoteräpicos e a grande probabilidade do desenvolvimento microbiano (67). Além disto, para aqueles produtos com fabricação en larga escalà, o risco associado à conta minação microbiana ganha maior dimensão $(62,138)$ tendo en vista a distribuição de um mesmo lote a grande faixa da população.

$H a ́$, portanto, lirgẽncia no estabelecimento ce normas nacionais que permitam o enquadramento destes produtos, gradativamente, aos padrões ce qualidade microbiológica, conscientizando os procutores a trabalhar em melhores concições, respeitando as Boas Nornas de Fabricação. Desta forma, a aplicação de padrões permitirà conhecer, indiretamente, as condições sanitárias de produção. 
Segundo Yokoya (219), no estabelecimento de normas de pureza microbiana, torna-se importante conhecer o risco que se quer evitar através do isolanento de microorganismos indicacores, levanco en consideração a via de administração do procuto além de outros fatores como o estado fí sico da forma farnacéutica (sólido, semi-sólico, líquido) es os recursos disponiveis para a suá obtenção (191). Ainda, o padrão deverä apresentar margem de toleräncia adequada, tencio em vistá a falta de exatidão proveniente dia anostragen e anälise. 0 pröprio monitoramento regular, durante o desenvolvimento e fabricação do produco leva à verificação e estabelecimento do tipo e número minino de microorganismos atingivel $(62,183)$, senco que a garantia de que esse nivel è compativel con a estabilioade micrabiológica do produto contitui o melhor manual de produção.

Sendo assim, a norma não constitui un valor estático, devendo sofrer alterações conforme o aprimoramento das condiçóes higiênicas da industria e de acordo con à modificação de procedimentos de fabricação (183).

No caso de fitoterápicos, o estabelecimento inicial de fadrões microbianos rígitos não é condição ideal para se alcançar a qualidace dese jável, una vez que pela origem dos mesmos, dificilmente serão obedecidos. Portanto, há que se extrapolar a icéia ce cortrole de qualicade de forma a abranger desde as primeiras etapas produtivas ca natéria-prina, como a cul tura, lavagem de drogas e possivel uso de solução desinfetante, alén da embalagem e conservação adequadas to produco acabado.

O embasamento legal dos padrões é importante, consitituindo sugestóes para adequar a produção a limites de contaminação tcleráveis com relação à inocuidade do produto.

A Farmacopéia da Tchecoeslovácuia (45) incluiu, pela primeira vez, limite microbiano para medicamentos não estéreis, tencio sido tolerante para a coniagen tóal $\left(5 \times 10^{4} / \mathrm{mL}\right)$, na medida en que requereu a ausència de determinacios nicroorganismos especificos (Tabela XXII) (og. 114). 
TABELA XXII - Limites de tolerância dos diferentes padrões microbiológicos para medicamentos não estéreis de uso oral

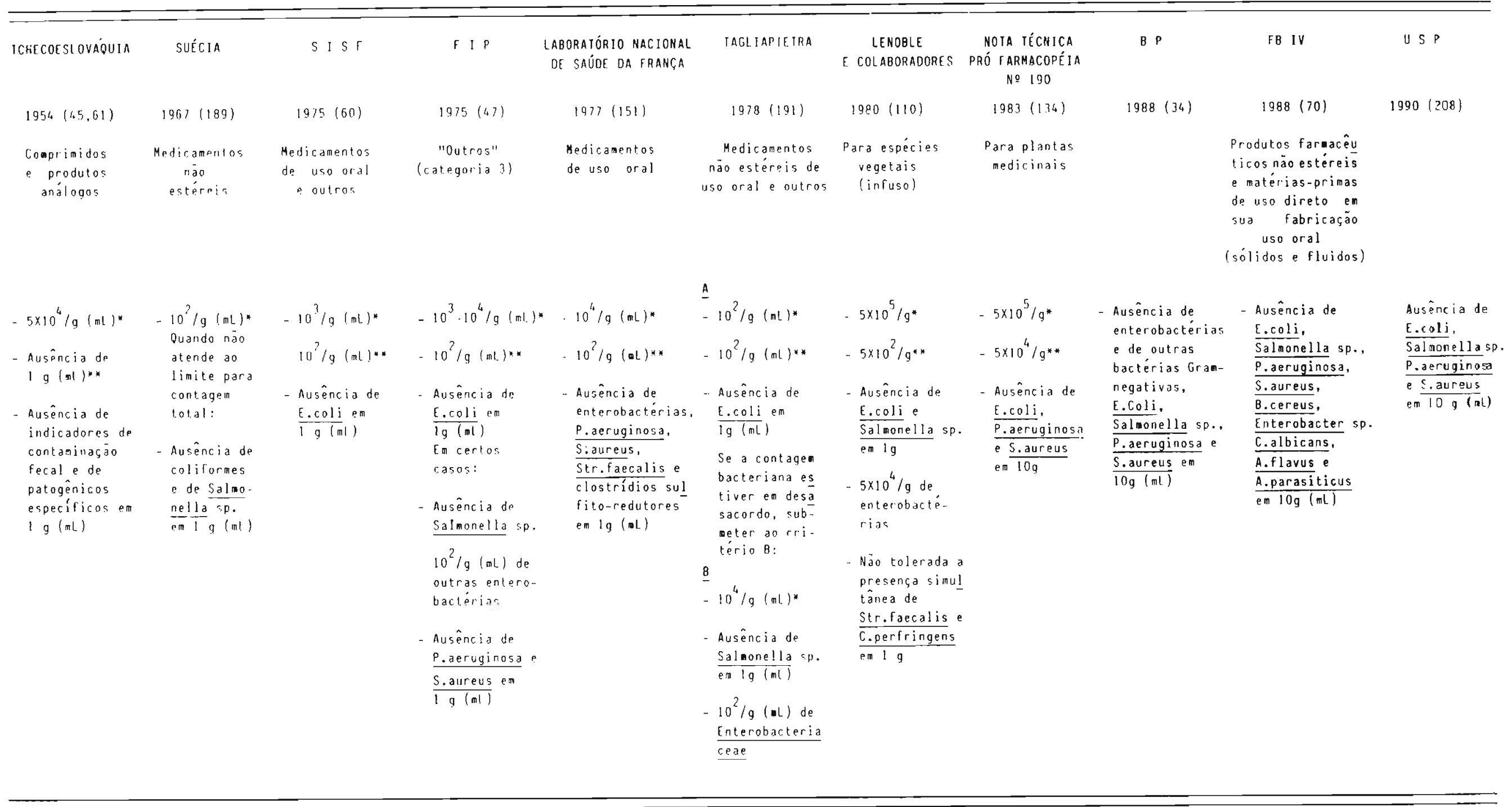

* bactérias aeróbias mesórilas

* bolores e leveduras 
As primeiras ocorrências de problenas clinicos en consequéncia do uso de medicamentos não estéreis contaminados servirar cie incentivo à elaboração de padrões, tendio surçico o sueco (189), en 1967, e cutras propostas na década de $70(47,110,191)$. Portento, a preocupação con a qualida de cestes produtos é relativanente recente, tendo despertado o interesse para com as crogas vegetais.

0 paórão sueco (189) (Tabela XXII) (pg.114) mosirou-se muito rígido quanco do linite da carga bacteriana, porér. justificadamente, en função dos casos de toxiinfecção verificados na época. No caso de produto contendo carga bacteriana inferior àquela preconizada por tal paóräo $\left(10^{2} / g\right)$, a pesouisa de microorganismos patogénicos é considerada desnecessária. Porén, em caso da exigencia não ser satisfeita, en função das matérias-primas de origem biológica, a pesquisa de espécies patogênicas deve atender à ausencia de coliformes e de salmonelas em $\mathrm{lg}$ (mL) de produto. No entanto, com a 2 a condição existe o risco de serem aprovados lotes com carga bacteriana alta com a jusíficativa de não conter os microorganismos indicados, conerastando con a 7 a exigéncia que visa excluir certos microorganismos pá togênicos ou potencialmente como tal, além daqueles indicadores de contami nação fecal (62), cuja presença é sinal de condições higiēnicas insatisfatörias de produção.

0 padrão proposto pela SISF (60) fixa en $10^{3} / \mathrm{g}$ o nivel märimo tolerado para bactérias aeróbias mesófilas, alén de limitar a pesouisa de microorgaismos especificos a Escherichia coli (Tabela XXII) (po.114). Limi t.e desta orden para a carga bacteriana torna difícil o cumprimento por par t,e destes produtos considerando sua oricem.

Os padrões que se sucederam tencerami à micr toleräncia quanto à carga total de contaninantes viáveis, tendo portanto exigido a verificação da presença ce microorganismos específicos (Tabela XXIJ) (Da.114). 
01 imite mäximo de $10^{3}-10^{4}$ bactérias/g sugerido pela FIP (47) pera medicamentos não estëreis de uso oral, alén de ser internacionalmente aceito, é aplicável para drogas vegetais, uma vez que se refere aos produtos constituindo "fonte inevitável de contaminação que não pode ser reduzi da efetivamente pelo processo produtivo". O mesmo se verifica na proposta. co Laboratório Nacional de Saúde da França (151), inclusive, havenco muita semelhança entre esses para os cemais requisitos (Tabela XXII) (pg.114).

A aplicação desses padrões aos procutos fitoteräpicos merece ainda algumas considerações. Tencio em vista a via de administração, a pesquisa sistemática de Pseudomonas aeruginosa e Staphylccoccus aureus tornase dispensável, diferentemente daquela de salmonella sp., que deveria apre sentar caräter de obrigatoriedace (110), apesar de o Laboratörio Nacional de Sáude da França não a ter considerado como patogênica (151).

Por outro laoo, o limite de tolerância zero para enterobacté rios, recomencado pela norma desse pais (151) è muito rigido para drogas vegetais, sendo criticável. Diferentemente, a FIP (47) sugere nivel inferi or a $10^{2} / \mathrm{g} \mathrm{mL}$ para outras enterobactérias, alén de Escherichia coli e Salmonella sp. para medicamentos não estéreis de uso oral, a aue seria mais viável para os produtos considerados do que a ausência recomendada pelo pa drão francès (151). Esse último contéra ainda requisito para a auséncia de estreptococos fecais e clostrídios sulfito-redutores, como indicadores de contaminação fecàl. Essa comissão optou por esses microorganismos, ao in vés de Escherichia coli, por considerar que não é a espécie mais patogênica entre as enterobactérias.

A indefinição da propostầ da FIP (47) quanto à pesquisa de microorganismos especificos, excluindo Escherichia coli na expressão "certos casos", pode dificultar o controle microbiológico. Porém, a rejeição de lo te contendo Escherichia coli em l grama de produto é perfeitamente aćequada, pois visa eliminar o risco ce contaminação fecal recente. Essa pode 
provir, no caso dos fitoterápicos, da recontaminação decorrente de más con ciições de produção, tendo em vista que, com os tratamentos sucessivos no cecorrer de sua transformação pode ocorrer diminuição na carga inicial pro veniente dos insumos.

As normas sugeridas por Tagliapietra (191) (Tabela XXI1) (pg. 114), erii 2 níveis estão na dependencia da carga bacteriana, pois se esta excedier $10^{2} / \mathrm{g}(\mathrm{mL})$, deve-se pesquisar salmonella sp., além de realizar a contagem de enterobactérias. Tendo em vista a carga microbiana alta dos produtos analisados, isto implica, geralmente, na aplicação do 20 nivel de exiçencia, tendendo à aprovação de lote com altó carga bacteriana.

Mais recentemente, en 1980, Lenoble e colaboradores (110) suge riran padrão especifico para espécies vegetais destinadas ao uso na forma de infuso, cujo nivel de tolerância para carga bacteriana, fúngica e de en terobactérias é alto com relação a outras normas microbiológicas (Tabela XXII) (pg. 114).

En 1983, a Nota Técnica Pro-Farmacopéia no 190 (134) introóuziu padrão similar ao anterior, para olantas medicinais, senco igualmente tolerante auanto à carga bacteriana (de até $5 \times 10^{5} / \mathrm{g}$ ) e sobretudo para fungos $\left(5 \times 10^{4} / 9\right)$. Fica questionävel para aqueles casos em que, diferente mente dos produtos destinados à infusão, não ocorre processamento prévio. Sabe-se que tal procedimento possibilita a redução da -arga conteminante $\underline{i}$ nicial de 1 à 2 logaritmos decimais $(110)$, porén, para os produtos consumi dos sob a forma de cápsula e pó, a toleráncia parece ser demasiada.

Quanto ao requisito para contaminação fúngica, quando existente en nomas microbiolögicas para medicamentos não estéreis, constata-se $\underline{u}$ nanimicade $(47,60,151,191)$ para o limite de toleräncia, senco de $10^{2} / \mathrm{g}$ (Tabela XXII) (pg. 114), parecendo, portanto, adequado para una boa conser vação do produto. 
Comparativamente, os padrões mais tolerantes são suscetiveis de critica, pois, de acordo com o teor de umidace do produto e das condições de armazenamento, pode haver comprometimento da integridade do mesmo.

No que se refere a enterobactérias e salmonelas, o padrão da Nota Técnica Pro-Farmacopéia (134) exige ausência de Escherichia coli/g, e outras diferentemente daquele de Lenoble e colaboradores (110), que apresen ta limite para as primeiras $\left(5 \times 10^{4} / g\right)$ superior àquele sugerido para medi camentos não estéreis de uso oral $\left(10^{2} / \mathrm{g}(\mathrm{mL})\right)(47,151)$, o que pode ser em função de se tratar de produtos naturais. Apesar dessa tolerāncia, recomen da auséncia de Salmonella $\mathrm{sp}$. em $1 \mathrm{~g}$, além de pesquisar, simultaneamente, 3 indicadores de contaminação fecal: Escherichia colí, estreptococos fecais e clostridium perfringens.

A proposta da Nota Técnica no 190 (134) apresenta, esisranhamen te, exigencia com relação à auséncia de Pseudomonas aeruginosa e Staphylococcus aureus apesar da via de administração estar subentendida. 0 mesmo se verifica nas exigēncias do Farmacopéia Brasileira IV (70) para "produtos farmacêuticos não estéreis e matérias-primas de uso direto em sua fabricação", pois mesmo quando se trata de produtos de uso oral "sölidos e fluicos" recomenda a pesouisa destes microoranismos, alëm de Escherichia coli, de Salmonella sp. e de outros. Portanto, segue a tendéncia norte-ame ricanâ (USP XXII) (208), que requer os testes para ausēncia das mesmas bac térias. No entanto, como requísito adicional, no caso de produto administrado via oral, exige a ausencia de Bacillus cereus, Enterobacter sp., Can dida albicans, Aspergillus flavus e Aspergillus parasiticus (Tabela XXII) (pg. 114), demonstrando preocupação semelhante àquela para com alimentos.

Com relação à Farmacopéia Britänica (34), as exigèncias quanto $\bar{a}$ ausência de patogénicos específicos são as mesmas que da Farmacopéia Ame ricana (208), complementadas pela ausencia de enterobactérias e de outros microorganismos Gram-negativos. 
Portanto, há diferentes implicações quando do confronto dos da dos encontrados neste trabalho em relação aos padrões.

Considerando os ítens analisados nesta amostragen de fitoterápicos brasileiros, sem se preocupar em atender todos os requisitos especificados en diferentes niveis de exigència anteriormente comentados, a frequēncia de aprovação variou de 29,8 a $94,0 \%$ (Tabela XXIII) (pg. 120), tendo sido a norma da SISF a mais rígida de todas. Este resultado permite con cluir que a maior toleráncia do padrão reside na não exigéncia da contagem total de sapröfitas (bactérias e fungos). Por sua vez, à medida que a tole rància neste aspecto é decrescente, o indice de aprovaçào diminui. É por isto que pela USP XXII a rejeição foi baixa. Constata-se, ainda, que tanto a Farmacopéia Brasileira IV (70) quanto o padrão sueco e aquele da Farmacopéia Britänica $\{34$ \} apresentam as mesmas percentagens de aprovação, apesar do sueco ser aparentemente mais rigido (Tabela XXII) (pg. 114).

É interessante observar, ainda, que em relação a todos os padrões estudados, o resultado analitico foi melhor para comprimido, seguido de cápsula e dó (Tabela XXIII) (pg. 120), sendo que os padröes mais rígidos rejeitaram todos ou quase tojos os lotes, o que é coerente com a má qualidade verificada nestas amostras.

Tomando-se por base padrões com niveis de toleräncia extremos em função do tipo de produto a que se destinar! como, por exemplo, aquele da FIP (47) e os 2 destinados a espécies vegetais $(110,134)$, verifica-se que o primeiro é mais adequado, quanto acs limites para microorganismos viä veis totais e especificos, podendo ser aplicado aos produtos fitoterápicos, com a ressatva de se pesquisarem as espécies microbianas airetamente relacionadas à via de administração. Contrariamente, as normas para plantas me dicinais (134) e para espécies destinadas j̀ infusão (110) não parecem ser suficientemente rigidas para garantir o nível adequacio de qualidade, tendo 
ThM

\begin{tabular}{|c|c|c|c|c|c|c|c|c|c|c|c|}
\hline & $1.55 \times x[]$ & $\begin{array}{c}\text { NOTH TÉCNICA } \\
\text { PRÓ- } \\
\text { TARMACOPÉ I n } \\
\text { No } 190\end{array}$ & LENORLE & surcin & F.日. IU & BP 1980 & IAGLIAPIEIRA & $F\rfloor P$ & $\begin{array}{c}\text { ICHECO- } \\
\text { ESLOVÁOUIA }\end{array}$ & $\begin{array}{l}\text { LABORATÓRIO } \\
\text { MACTONPLL } \\
\text { DE SAÚOE DA } \\
\text { FRAMCYA }\end{array}$ & SISF \\
\hline \multirow{2}{*}{ Br MMOSTRAS } & 34,0 & 78.6 & 85,5 & 52,4 & 52,4 & 52,4 & 40,5 & 40,5 & 34,5 & 32,1 & 29,8 \\
\hline & $179\}$ & $\{65\}$ & (55) & $(44)$ & (44) & $(46)$ & $(34)$ & $136)$ & {$[29]$} & $\langle 27\}$ & $\{25\}$ \\
\hline 1E RHOSTRAS APROUAOAS OURMTO nO & 100.0 & 86.7 & 80,0 & 5.3 .3 & 53,3 & 53.3 & $4,6.7$ & 46,7 & 26.7 & $4,6,7$ & 40,0 \\
\hline BSPECIU DE APRESTMAGEAO COMFRETAL & $(15)$ & (13) & $(12)$ & $(8)$ & (9) & (8) & (7) & (7) & {$[4]$} & (7) & (6) \\
\hline COMPAJMIDOS & 100,0 & 85,7 & 81,0 & 66,7 & 66.7 & 66,7 & 52,4 & 52,4 & 57,1 & 38,1 & 60.0 \\
\hline$(79)$ & $(21)$ & $(18)$ & $(17)$ & $(14)$ & $(14)$ & $(14)$ & (11) & $\{11\}$ & $(12)$ & $(8)$ & $(9)$ \\
\hline FORMA FARMACÊUTICA & 93.8 & 83,3 & 68.8 & 52.1 & 52.1 & 52,1 & 50,0 & 45,8 & 35,4 & 37,5 & 33,3 \\
\hline$(48)$ & $(4,5)$ & $\{40\}$ & (33) & $(25)$ & $(25)$ & $(25)$ & $(24)$ & $(22)$ & (17) & (18) & (16) \\
\hline \multirow[t]{2}{*}{ pós } & 86,7 & 53.3 & 33,3 & 33.3 & 33,3 & 33,3 & 13,3 & 6.7 & - & 6.7 & - \\
\hline & $(13)$ & {$[8]$} & $(5)$ & (5) & (5) & (5) & (?) & (1) & $(0)$ & $(1)$ & $(0)$ \\
\hline
\end{tabular}


em vista tratar-se de produtos com forma farmacêutica definida, devendo, pelo menos, tender a iqualar-se àquele de cutros medicamentos não estéreis. Alèm disso, considerando a via oral de administração o padrão da Nota Técnica Pro-Farmacopéia no 190 (134) apresenta falha no que se refere à omissão do requisito para salmonelas, além de ser tolerante demais com relação à carga bacteriana e füngica. No caso da norma proposta por Lenoble e colaboradores (110), a maior toleräncia referente ao nivel de contaminação bacteriana leva em consideração o preparo do infuso antes do seu consumo.

Desta forma, ac se confrontar os dados encontrados em amostras brasileiras (Tabelas, XVII, XVIII, XIX, XX, XXI) (pg. 66,67,68,69,70) con estas trés normas microbiológicas (Tabela XXII) (pg. 114), verifica-se resultado discrepante em relação aos padrões da Nota Técnica no 190 (134) e da FIP (47), pois $66(78,6 \%)$ e $34(40,5 \%)$ lotes preencheram, respectivamen te, estas exigências.

Esta frequència de aprovação é preocupante, uma vez que muitas amostras são aprovacas apesar de estaren com carga bacteriana ou fúngica a cima de $10^{4} / \mathrm{g}$. Consequentemente procutos com qualidade muito aquém dacuela cesejável para medicamentos não estéreis serão colocados à disposição do consunidor.

Alêrn disso, entre os lotes rejeitados pelos 2 padröes estão envolvidas 6 e 11 espécies vegetais, respectivamente, para o menos e o mais ríaido. Desta forma fica evidente que o padrão mais tolerante pode mascarar a qualidade variável de amostras contendo o mesmo insumo fitoterápico, apesar das diferenças de produtores, forma farmacêutica e, até mesmo, entre lotes distintos de unn mesmo produto.

Ao se confrontar os resultados analiticos das 15 amostras que atenceram às exigencias legais quanto à apresentaçào comercial com todos os pacrões de pureza microbiana arrolados (Tabela XXII) (pg. 114), quadro 
semelhante àquele apresentado pelo total da amostragem é verificado (Tabe1 a XXIII) (pg. 120), sendo que, neste caso o percentual de aprovação está entre 40 e $100 \%$.

Feitas as devidas ressalvas quanto ao número reduzido de amostras analisadas no caso de certos produtores, na comparação entre os 20 abrangidos por esta amostragem constata-se que o produtor A apresenta todos os lotes en concordäncia com a legislação sanitéria vigente $(24,25)$ (Tabela I) (pg. 51), além de que a pureza microbiológica está satisfatória em seus produtos, exceto naquele contendo guaraná. Porén, conforme comentado anteriormente, amostras de outros fabricantes contendo esta droga apresentaram má qualidade. Portanto, nota-se que o produtor A atua no mercado far macéutico nacional obedecendo aos requisitos de qualidace desejävel o que não acontece com os demais produtores.

Apesar da amostragem limitada, pode-se tecer algumas considera ções sobre os produtores $M$ e 0 , que iqualmente apresentaram interesse quan to à obediência à legislação (Tabela I) (pg. 51). Para o produtor $M_{1}$ não houve coerencia entre aspecto de apresentação comercial adequada e a qual dade microbiana, uma vez que os niveis de contaminantes viáveis foi da ordem de $10^{3} \%$ g (Tabela XXI) (pg. 70), o que é preocupante com relação à carga füngica. Já o produtor 0 revelou qualidade desejável en amoos os aspectos (Tabelas I e XXI) (pg. 51 e 70).

Dos outros 2 produtores ( $C$ e $K$ ), cujas amostras estão em acordo com as exigencias legais (Tabela I) (pg. 51), estas apresentaram diferentes dados frente à contaninação microbiológica (Tabela XXI) (pg. 70). us 5 lotes de $C$, correspondendo a guaraná (4) e boldo (1) apresentaram con tagem bacteriana superior a $10^{4} / \mathrm{g}$, com alguns deles contendo altos niveis de fungos. Portanto, a má qualidade foi constante para estes produtos. Já, - produtor $k$ con 3 lotes amostrados $(1$ de alcachofra e 2 de guaraná) demonstrou auséncia de padrão de qualidade, mesmo no que se refere à obediên 
cia à legislação para comercialização, visto que 1 dos lotes de guaraná es tava em desacordo (Tabela. I) (pg. 51). Diferentemente de outros produtores, este apresentou, para ambos os lotes contenco esta droga, qualidacie adequa. da, apesar de o miesmo não se ter verificado para alcachofra, cujas cargas bacteriana e füngica superaran, respecivivanente, $10^{4}$ e $10^{2}$ por grama.

Eom relação aos demais produtores que aparentemente atuan neste mercado com meior fatia $(B, L, G)$, apesar de terem sido verificados alguns lotes com qualidade microbiológica melhor, a meioria não estava satis fatória, tencio predominado niveis microbianos quase sempre altos (Tabelas XVIII, XIX, XX) (pg. 67,68,69). Para o produtor $G$ é fácil a distinção do nivel de qualidade de produtos contenco guaraná e levedura de cerveja, sen do claramente melhor no segundo caso, comprovando, mais uma vez, a auséncia de uniformidace e de padrão de qualidade para um mesmo produtor.

0 quadro delineado para os fitoterápicos através de resultados encontrados em produtos amostrados neste trabalho representa alerta para o risco a que se sujeita o consumidor destas especialidades farmacéuticas, pois, conforme já comentado, nem sempre se trata de produção em escala artesanal, o que dá maior significado ao problema da contaminação microbiana. Há necessidade, porzanto, de conscientização por parte dos produtores com relação à responsabilidade para corn o consumidor.

Com relação à situação brasileira no que tange às especificações farmacopéicas, verifica-se que, das espécies vegetais relacionadas à presente amostragen, apenas al gumas constam da Farmacopéia Brasileira, sen do: alcachofra $(69,71,152)$, boldo $(71,152)$, carvão medicinal $(69,152)$, cas tanha da India $(71,152)$, catuaba (152), guaraná $(69,71,152)$, levedura de cerveja (69,71,152) e zedoária (152). Porém, destas, apenas levedura de cerveja, como insumo, apresenta padrão microbiano, na segunda edição (71). Os linites de colerãncia para carga bacteriana e fúngica são, respec tivamente, $7,5 \times 10^{3} / g$ e $50 / g$. Ao confrontá-los com os resultados obtidos 
nos lotes correspondentes (Tabelas XVII, XVIII, XIX, XX e XXI) (pg. 66,67, $68,69,70)$, constatam-se 9 dentre $11(81,8 \%)$ em conformidade com estes re quisitos. Porém, se deve fazer adaptação do limite microbiano para a forma farmacêutica, uma vez que ao reportar-se a $1 \mathrm{~g}$ de matéria-prima, sabe-se que o conteúdo de insumo ativo presente er 1 unicade farmacẽutica (cápsula ou comprimidol é inferior, havendo, portanto, diluição da carga contaminan te original do insumo fitoterápico, possivelmente em mistura com excipientes.

A mesma observação aplica-se aos demais padrões ritcrobianos es tudados referentes a plantas medicinais e drogas para infuso (Tabela XXII) (pg. 114).

Considerando a situação brasileira, tanto pela ampla utilização de drogas da medicina popular, assin como pela inexistencia de requisi tos microbianos específicos en monografias farmacopéicas de drogas vegetais, defronta-se con resultado desta ordem, indicando a falta de controle de qualidade por parte do produtor. Impõe-se. assim, a necessidade de atualização das monografias com a inclusão das drogas mais utilizacias e das especialidades fitoterápicas correspondentes, bem como a especificação de normas microbiológicas, a exemplo do que ocorre em outros países $(34,208)$.

0 programa da Central de Medicamentos (CEME) para a pesquisa de plantas medicinais selecionou, em 1986,36 espécies vegetais, oficiais ou não, a fim, Ge serem estudadas, combase cientifica. Isto permitirá a implantação da terapéutica alternativa e complementar, visando favorecer a faixa carente da população, de forma a integrar, futuramente, a Relação Ną cional de Medicamentos Essenciais (RENAME). Como o periodo de aquisição das amostras para este estudo foi imediatamente posterior ao prograna da CEME, dentre as 17 espécies botänicas integrantes desta anostragem, apenas confrei e espinheira santa fazern parte do "primeiro elenco" de plantas selecionadas $(26)$. 
Verifica-se, portanto, que a maioria das drogas da presente amostragem não consta da lista com possibilidade de inclusão na RENAME, o que contrasta com a sua ampla comercialização. Entretanto, futuramente poderà ocorrer mudanças neste panorama.

O direcionamento para a terapeutica à base de plantas cientifi camente reconhecidas cono medicinais representa o inicio do uso correto das especialidades fitoteräpicas. Assim, a inclusão de drogas vegetais na RENAME imolicará no reconhecimento. a nivel nacional, de sua iniportäncia na terapéutica e com isto impondo a necessiciade do controle de qualidade dos fitoterápicos dentro dos padiões exigidos pára medicamentos não estéreis.

Ainda, consideranco as especialidades fitoterápicas, o estabelecimento do padrão microbiano deve ter como base 2 aspectos: as características originais inerentes à aroga vegetal em questão, fornecendo qualidades próprias a essa classe de produtos farmacêuticos, bem como o nivel de qualidade desejävel para medicamentos, visando a eficácia terapéutica com segurança do paciente.

Tanto o produtor de insumos fitoterápicos, cono o seu consumidor que participa na sua transformação para medicamentos deve efetuar levantamentos da qualidade cujo histórico servirá corio ponto de partida para suâ adequação às características farmacèuticas.

Alguns comentários podern ser feitos diante dos dados experimen tais obtidos, bem cono daqueles verificados por outros autores para órogas vegetais, além dos diversos padrões encontrados na literatura (Tabela XXIII) (pg. 114). A preocupação con a qualidade microbiológica destes produtos de ve englobar não somente a ausēncia de microorganismos especificos, como tambéri a ceterminação de contaminantes sapröfitas totais, visando a idonei dade do produto. Para isto, os niveis de toleráncia estipulados pela fip (47) e pelo Laboratório Nacional de Saúde da França (151) para as cargas 
bacteriana e fúngica parecem adequados, já que o limite $\frac{d}{10} 0^{4}$ bactérias por grama e de $10^{2}$ fungos por grama està levando em consideração a origem vegetal do insumo, bem como a manutenção da qualidade desejável para medica mentos não estéreis. O limite de carga füngica recomendado também por outras normas $(60,191)$, considera a necessidade de se evitar espécies toxigènicas, cuja probabilidade de ocorréncia passa a existir quando o nivel destes contaminantes ultrapassa tais valores.

A pesquisa de Escherichia coli e Salmonella sp. è indispensável, em função da via de administração a que se destinam estes produtos, a fim de controlar, inclusive, a introdução das mesmas durante sucessivas manipulações.

01 imite de $10^{2} / \mathrm{g}$ enterobactérias, exceto Escherichia coli, conforme a proposta da FIP (47) parece igualmente adequado, tendo en vista que padrões menos rigidos se aplicam a espécies vegetais destinadas à infusão (11).

Em adição às exigencias do padrão FIP, a pesquisa da presença simultänea de estreptococos fecais e clostrídios sulfito-redutores será desejável com o objetivo de se descartar a possibilidade de contaminação fecal remota. Especificamente, com relação a clostrídios, sua pesçuisa se ria recomendável nos casos en que o processo de manipulação necessariamen te envolve o tratamento térmico, durante o qual as células vegetativas de Escherichía coli e estreptococos poderiam ser destruidas, mas permanece riam os esporos do primeiro, e assim poderiam indicar se houve ou não con taminação fecal.

Na pesquisa de bolores, certas espécies são indesejäveis, en função da produção de micotoxinas. Desta forma, a ausēncia de Aspergillus flavus, usualmente encontrada em drogas vegetais $(150,171)$, deveria ser in dicada à semelhança da exigéncia dâ Farm.8ras.IV (70). Todas estas exigèn 
cias para espécies patogennicas especificas devem levar em consideração, se melhantemente aos métodos farmacopéicos mais recentes (USP XXII, 1990; Farm. Bras. IV, 1988; BP, 1988), a tomada de ensaio de $10 \mathrm{~g}$, por ser mais represen tativa do que aquela recomendada em outros padrões microbianos, porém, a tomada de $1 \mathrm{~g}$ pode ser admitida quando o nivel de toleráncia é maior em fun ção do risco de ocorréncia. Sugere-se, portanto, o seguinte limite microbiano como proposta:

- bactérias aeröbias mesöfilas: $\leqslant 10^{4} / \mathrm{g}(\mathrm{mL})$

- fungos: $\leqslant 10^{2} / \mathrm{g}(\mathrm{mL})$

- Escherichia coli: auséncia eri $10 \mathrm{~g}(\mathrm{~mL})$

- Salmonella sp.: auséncia em $10 \mathrm{~g}$ (mL)

- Streptococcus faecalis: ausencia em $1 \mathrm{~g}$, para insumos constituĩdos de örgãos subterrāneos

- Clostridios sulfito-redutores: ausência em $\mathrm{lg}$, para insumos constituídos de örgãos subter ràneos e em produtos envolven do tratamento térmico durante a manufatura

- Aspergillus flavus: auséncia eril $10 \mathrm{~g}(\mathrm{~mL})$, para insumos constituídos de semente

Tendo admitido a implantação de padrão de qualidade para fitote rápicos, incluindo a microbiana, ainda que a caráter provisōrio, medidas mais sérias cievem ser tomadas pela fiscalização, a fim de que os fabricantes cestes produtos se enquadrem às normas gerais impostas parâ produção e comercialização de medicamentos não estéreis de uso oral. Novas propostas poderão ser adotadas, fundamentadas em experiencias anteriores, cujo nível de exigencia tenhà sido gradativamente ajustado até o ideal. 
Desta forma, o seu esiabelecimento será fundamental para o enqua oramento dos producores ao conceito de controle de qualidade abrangente, desde a certificação da identidade botànica, a análise quali e quantitativa dos principios ativos, bem como a qualidade sanitäria das especialioades farmacēuticas fitoterápicas. O respaido na legislação é fundamental, a fim de garantir a devida aplicação de normas de qualidade. Estas não constituem simplesmente valores numéricos estanques, mas pontos de referéncia que visam orientar os produtores na melhoria da qualidade, indispensável à segurança do consumidor. Alén disso, considerando o consumo em grande esca 1a, quase sempre por auto-medicação e os problemas verificados no passado com a contaminação de medicanentos não estéreis de uso oral, é inadmissivel o descaso atribuido, atualmente, a esta gama de medicamentos. 
7. CONCLUSÕES

7.1 Os medicamentos fitoteräpicos analisados estão no mercado farmacêutico nacional apesár de a grande maioria estar en desacordo com a legis lação pertinente, quanto aos requisitos cie apresentação comercial, una vez que apenas $17,0 \%$ das amostras atendem a tais exigenncias.

7.2 Não há consenso por parte dos produtores de especialidades fitoterápị cas quanto ao enquadranento das mesmas como medicamentos alopáticos, homeopáticos, produtos dietéticos ou ainda como alimentos.

7.3 A lei de vigiläncia sanitäria de medicamentos deve incluir, explicita mente, os fitoterápicos como medicanentos alopáticos, cuja comerciali zação deve ser subnetida à fiscalização como tâ.

7.4 Dentre as formas farmacêuticas sölidas amostradas no comércio da cida de de são Paulo houve predominância de cápsulas, seguida ce compriritdos e pōs.

7.5 Os rnedicamentos fitoterápicos constituidos de drogas vegetais apresen tam qualidade sicrobiana inferior en relação àqueles contendo drogas derivadas.

7.6 Hà estreita relação entre à carga bacteriana aeróbia mesófila e de esporos de bactérias aeróbias mesófilas.

7.7 A contaninação füngica, nem sempre apresentando relação direta com a carga contaminante bacteriana, compromete menor percentagem de amostras. 
7.8 A qualidade sanitária inadequada de alguns produtos fitoterápicos indicou presença simultánea de Escherichia coli e de Salmonella sp., ao lado de altas cargas de contaminantes saprofitás.

7.5 Os dados analiticos relacionacos aos fitcierápicos de produtores de ande foi possivel amostracen mais representativa indican que não hà controle de qualidade.

7.10 0s dados analiticcs dos fitoterápicos amostracios, sob o ponto de vista sanitärio, quando confrontados do padrão microbiono da FIP, indican situação preocupante, pois $59,5 \%$ das amostras são rejeitadas.

7.11 A incicéncia de carga contaminante viāvel totâl elevaća ocorreu en amostras de pó, secuida de cápsulas e comprimiclos, independentemen te da origeri botānica envolvida.

7.12 Há necessidade imperiosa de implaniação de padrão ricrobiano nácio nal pare medicarentos fitoteräpicos, ainca que conc proposía, a fim de que gradativa e progressivarente venha a constituir os limites de toierância a serer obeciecidos pelos procutores.

7.13 Pela análise crítica dos civersos pécéces ricrobionos, acuele cia FIP, com algumas adaptações, poce ser sugerico corco propostic inicial anlicável aos nedicarentos fitoteräpicos nacicnais. 


\section{RESUMO}

Foram analisados 84 lotes de especialicades fitoterápicas de $\underline{u}$ so oral, na forma de cápsula, comprimido e pó, contendo 17 drogas vegetais, produzidas por 20 fabricantes e comercializadas em farmacias, drogarias, 10jas de produtos naturais e supermercados da cidade de São Paulo. O confronto da apresentação comercial das mesmas em relação à leçislação nacional, indicou que a minoria (15/84) atendeu a tais exigencias, alén de ter denonstrado total falta de padronização de qualidade pelos produtores, inciusive com ausência de definição e conceituação, enquadrando-as indistintamente como me Gicamentos alopáticos, homeopáticos, produtos dietéticos ou al imentos. Efetú ou-se a quantificação de bactérias aeróbias mesófilas (forma vegetativa e es porulada) e de fungos (bolores e leveduras), através da técnica de tubos múl tiplos, ben como a pesquisa de Escherichia coli e Salmonella sp. pela metodo logia oficial internacional. A contaminação fúngica, predominantemente de bo lores, foi inferior em relaçào à bacteriana aeröbia mesófila, pois o máximo detectacio para aquela foi de $4,6 \times 10^{5}$, enquanto que para esta $5,1 \times 10^{9} / \mathrm{g}$. A incidencia füngica con carga maior ou iqual a $10^{2} / \mathrm{g}$ foi de $34,5 \%$, contra $53,6 \%$ la carga bacteriana vegetativâ con $10^{4} / g$ ou mais e $45,2 \%$ da bacteriana

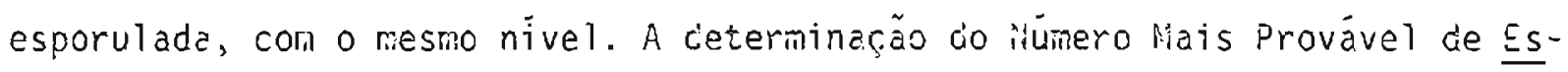
cherichiá coli indicou incidéncia de $6,0 \%$ con a carga maior igual à $1,5 x$ $10^{2} \%$. Houve estreitá relação entre a carga bacteriana vegetativa total e o nünero de esporos, assin cono à presença de patogênicos especificos en: procu tos altamente contarinados. Amosiras sob a forme de pó foran as mais aferadas, seguidas de cápsulas e comprimidos. Pelo confronio dos dados encontrados, corii os diversos padrôes microbianos âplicados para medicamentos rião es¿éreis de uso oral, para insurios e produtos fitoterápicos, o incice de apro-

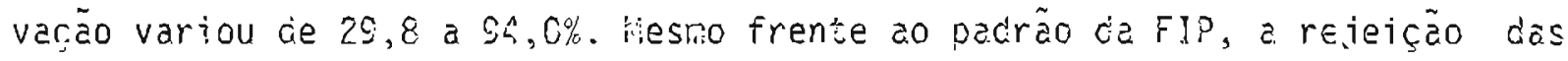
especialicades fitocerápicas analisadas foi dá orden de 50,5\%. Em vista da qualicade sanisäria de tilitos destes procutos ser impropria para o consumo, 
e após anàlise crítica dos värios padrões microbianos, discutiu-se a necessidade de implantação de especificações nacionais, ainda que a caräter pro visörio, sugerindo-se limites de tolerância para medicamentos fitoterápicos de uso oral. 


\section{SUMMARY}

84 samples of phytotherapic products of oral solid dosage forms (capsules, tablets and powders) containing 17 different crude drugs and produced by 20 laboratories, marketed in drugstores, herborist's and supermarkets at São Paulo-Brazil were analysed with regard to legal marketing re quirements, only 15 samples were in accordance. A complete lack of quality standard was attributed to the manufacturers, including indefinition as to the classification of products among allopathic or homeopathic pharmaceuticals or foods or dietetics. The total aerobic bacterial (vegetative and spo rulated forms) and fungal (moulds and yeasts) contents were determined by multiple tube technique; moreover tests were carried out for Escherichia co $1 \mathrm{i}$ and Salmonella sp. by official international methods. The fungal contami nation was predominantly of moulds and lower than the aerobic bacterial one. The maximum counts were $4,6 \times 10^{5}$ and $5,1 \times 10^{9} / \mathrm{g}$, respectively, for fungi and bacteria. The frequency of samples with or more than $10^{2}$ fungi/g was $34,5 \%$ that for vegetative and sporulated bacterial counts with or nore than $10^{4} / \mathrm{g}$ was respectively, 53,6 and $45,2 \%$. The incidence of Echerichia coli was abou: $6,0 \%$ with the highest level at $1,5 \times 10^{2} / \mathrm{g}$. There was a tight relation between the vegetative and spcrulated bacterial counts as well as the presen ce of specific pathocenic riicroorganisms in highly contaminated samples. The highest contamination occured in powders followed by capsules and tablets. Comparing our experimental data with the corresponding microbial standards for oral non sterile pharmaceuticals, crude orugs and phytotherapic products, the index of approval varied between 29,8 and $94,0 \%$. Even by FIP's standards $59,5 \%$ of the phytotherapic specialties analysed had to be rejected. As many of these products showed innadequate sanitary quality for consumption, coupled to a critical analysis of the different microbial standards, the discu tion was raised about the necessity of establishing national specifications, even if provisional. Suggestions are made as to the contamination limits of oral phytotherapic pharmaceuticals. 


\section{REFERÊNCIAS BIBLIOGRÁFICAS *}

1 - AKERELE, 0. Medicinal plants and primary heâlth care: an agenda of action. Fitoterapia, Milano, v. 59, n. 5, p. 355-363, 1988.

2 - AMERICAN PUBLIC HEALTH ASSOCIATION. Standards method's for the examination of water and wastewater. 13. ed. Washington: American Water Works Association and Water Pollution Control Federation, 1971.

3 - AMERICAN PUBLIC HEALTH ASSOCIATION. Technical Committee on Microbiological Methods for Foods. Compendium of methoos for the microbiological examination of foods. 2. ed., Washington, 1984.

4. - Antico, G., guiggi, A., imazzoldi, G., paravioino, C., vianello, G. 5. Norme di Buena Fabbricazione. Boll.Chim.Farm., Milano, v. 114, n. 4, p. 190-200, 1975.

5 - ARRIBAS, M. L. G., JORGE, M. C.R., ROMEO, M. A. M. Caractërisation et sensibilité aux antibactériens des souches de coques à granı positif isolées à partir de médicaments solides adriinistrés par voie orale. J.Pharm.Belg., Bruxelles, v.38, n.3, p.140-146, 1983.

6 - ARRIBAS, M. L. G., DE LA ROSA, M. C., BOSSO, L. A. Caractérisation des souches de Bacillus isolées à partir de médicaments solides administrés par voie orale. Pharm. ActaHelv., Zurich, v. 61, n. 1011, p. 303-307, 1985 .

\footnotetext{
* De acordo cam a norma n8R 6023/89, preconizada pela associaçá BRASILEI RA DE NORMAS TÉCNICAS (ABNT). As abreviaturas dos títulos dos periódicOS seguem O CHEMICAL ABSTRACTS SERVICE SOURCHE INDEX (CASSI), 1990.
} 
7 - ASSOCIATION OF OFFICIAL ANALYTICAL CHEMISTS. Official methods of analysis, 14. ed., Arlington, 1984.

8 - AURELI, P., PASOLINI, D. Requisiti microbiologici dei farmaci non obbligatoriamente sterili. Boll.Chim.Farm., Milano, v. 124, p. 229$243,1985$.

9 - AURELI, P., FENICIA, L., SALVATORE, G. Microorganismi e piante aroma tiche; riflessi nell'impiego alimentare, cosmético e farmaceutico. Boll.Chim.Farm., Milano, v. 127, n. 5, p. 124-127, 1988.

10 - AYLIFFE, G. A. J., BARRY, D. R., LOWBURY, E. J. L., ROPER-HALL, M. J., WALKER, W. M. Postoperative infection with Pseudomonas aeruginosa in an eye hospital. Lancet, London, v. I, n. 7447, p. 1113$1117,1966$.

11 - AYLIFFE, G. A. J., BARROWCLIFF, D. F., LOWBURY, E. J. L. Contanination of disinfectants. Br.Med.3., London, v. 1, ก. 5539, p. 505, 1969.

12 - BAIRO, R. H. Microbiological control of pharmaceuticals. Pharm. Int., Amsterdam, v. 7, p. 255-258, 1986.

13 - BARZAGHI, D., BONOMI, E., CAFIERO, M., CARAZZONE, M., GENOVA., R., GIGLIOLI, N., NERI, G., VERONESE, M. Comparison of three bacterial count methods between laboratories. Boll.Chim.Farm., Milano, v. 119, n. 5, p. $309-313,1980$.

14 - BARZAGHi, D., BElla, G., BiANCO, L., BIZZARRI, D., BURINATO, C., CA RAZZONE, $M$. Ricerca dei clostridi solfitofiduttori in materie prinie per uso farmaceutico. Boll.Chim.Farm., Milano, v. 120, n.S, p. $528-535,1981$. 
15 - BASSET, D. C. J., STOKES, K. J., THOMAS, W. R. G. Wound infection with Pseudorionas multivorans. Lancet, London, v. 1, n. 7658, p. $1188-1191,1970$.

16 - BÉZANGER-BEAUQUESNE, L. Nouveautés en phytothérapie-cinquième revue. Plantes Méd. Phyto., Angers, v. 22, n. 1, p. 40-80, 1988.

17 - BICANOVA, M., THINSCHMIDT, G., MESKOVA, M. Fructus foeniculi and "Detsky caj's Hermankem". (Children's tea with chamomile from the microbiological aspect). Farm.0bz., 55 (Apr): 165-166, 1985. Apud: Int.Pharm.Abstr., Washington, v. 24, n. 7, p. 2404258, 1987.

18 - BISSON, J. W., CABELLI, V. J. Clostridium perfringens as a water pollu tion indicator. J.Wat.Poll.Contr., Washington, v. $52, n$. 2, p. $241-248,1980$.

19 - BONILHA, P. R. M. Microorganismos indicadores de contaminação fecal e enteropatogénicos em hortaliças e suas àguas de irrigação. 1986. [Dissertação de mestrado, São Paulo, Faculdade de Ciēncias Farmacēu ticas - U.S.P]

20 - BONOMI, E., NEGRETTI, F. Ricerche sul contenuto microbico di materie prime impiegatte nelle preparazioni farmaceutiche. Ann. Inst. Super. Sanità, Roma, v. 13, n. 4, p. 805-832, 1977.

21 - BOS, C. E., VAN; D. H., LERK, C. F. Microbiological stability of tablets stored under tropical conditions. Int.J.Pharm., Anisterdam, v. 55, n. $2-3$, p. $175-183,1989$.

22 - BOTTERELL, E. H., MAGNER, D. Nieningitis due to Ps. pyocyanea penetrating wounds of the head. Lancet., London, v. I, n. 6335, p.112-115, 1945. 
23 - BOWMAN, F. W., WHITE, H., LYLES, R. L. Microbial contamination of nonsterile antibiotic. Market samples: a survey. J.Pharm.Sci., Washington, n. 60, v. 7, p. 1099-1101, 1971.

24 - BRASIL.Leis, Decretos, etc. Decreto no 79.094, de 5 de janeiro de 1977. Regulamenta a lei $n=5.360$, de 23 de setembro de 1976, que submete a sistema de vigilância sanitária os medicamentos, insumos farmacéuticos, drogas, correlatos, cosméticos, produtos de higiene, saneantes e outros. Coleção de Leis e Decretos Federais, Brasīlia: Imprensa Naciona 1, 1977, v. 2, p. 16-68.

25 - BRASIL. Leis, Decretos, etc. Decreto $n=83.239$, de 6 de março de 1979. Altera o decreto de 5 de janeiro de 1977, que regulamenta a lei $n=6.360$, de 23 de setembro de 1976. Coleção de Leis e Decrecretos Federais. Brasilia: Imprensa Nacional, 1979, v. 2, p. 172173.

26 - BRASIL. Ministērio da Saúde. Central de Miedicamentos (CEME). Programa de Pesquisas de plantas medicinais: conjunto de plantas selecio nadas. $1 \cong$ e $2^{\circ}$ elencos. S.d.

27 - BRASIL. Ministério da Saúde. Secretaria Nacional de Vigiláncia Sanitária. Divisão Nacional de Vigiläncia Sanitäria de Alimentos.Por taria $n^{\circ} 9$ de 8 de março de 1985. Diärio Oficial, Brasilia, Seção 1, v. 49, p. $4420-4421,13$ fev. 1985.

28 - BRASIL. Ministério da Saúde. Secretaria Nacional de Vigilância Sanitäria. Divisão Nacional de Vigilância Sanitária de Alimentos.Por taria no 1 de 28 de janeiro de 1987. Diário Oficial, Brasilia, Seção 1, v. 125, p. 2197-2200, 12 fev. 1987. 
29 - BRASIL. Ministério da Saúde. Secretaria Nacional de Vigiláncia Sanitária de Alimentos. Retificação na Portaria no 001 de 28 de janeiro de 1987, publicada no D.0.U. n 29 de 12 de fevereiro de 1987 , Seção I pãg. 2198, anexo II ítem III. Diärio Oficial, Brasīia, Se ção 1, v. 125, n. 38, p. 2764, 25 fev. 1987.

30 - BRITISH pharmacopoeia. London: General Medical Counci1, 1932.

31 - BRITISH pharmacopoeia. London: The Pharmaceutical Press, 1953.

32 - BRITISH pharmacopoeia. London: Her Majesty's Stationery Office, 1973.

33 - BRITISH pharmacopoeia. London: Her Majesty's Stationery Office, 1980.

34 - BRITISH pharmacopoeia. London: Her Majesty's Stationery Office, 1988.

35 - BRUCH, C. W. Possible modifications of USP microbial limits and tests. Drug Cosmet.Ind., New York, v. 110, n. 6, p. 32-37, 116-121, 1972.

36 - BRUCH, C. W. Objectionable micro-organisms in non-sterile drugs and cosmetics. Drug Cosmet. Ind., New York, v. 111, n. 4, p. 51-54,150155, 1972.

37 - BüHLifANiN, X. Method for microbiological testing of nonsterile pharma ceuticals. Appl.Microbiol., Baltimore, v. 16, n. 12, p. 1919-1923, 1968.

38 - BÜHLMANN, V. X., GAY, M., HAUERT, W., HECKER., W. SACKMANN, W. SCHILLER, I. Prüfung pharmazeutischer Hilfsstoffen auf mikrobielle kontamination. Pharm. Ind. Aulendorf, v. 34, n. 8, p. 562-566, 1972. 
39 - BÜHLMANN, X., HESS, H. Mikrobiologische Reinheit von Arzneimitteln, die nicht steril sein mussen (gemeinsaner Bericht des Komitees Offizieller Laboratorien undDienststellen zur Prüfung von Medikamenten und der Sektion Industrie apotheker der FIP), Pharm. Ind., Aulendorf, v. 34, n. 11 a, p. 881-941, 1972.

40 - BUOGO, A., RATTI, L. Methods for the microbiological control of non sterile drugs. Farmaco Ed.Prat., Pavia, v. 27, n. 9, p. 523-531, 1972.

41 - BUOGO, A., GUERRATO, G., GIULIONI, A., PAPAKRISTO, G. Aspetti mi crobiologici dell'ambiente farmacêutico. Boll.Chiri.Farm., Milano, v. 118, n. 1, p. 9-17, 1979.

42 - BURDON, D. W., WHITEY, J. L. Contamination of hospital disinfectants with Pseudomonas species. Br.Med.J., London, v. 2, r. 5545, p. 153-155, 1967.

43 - CALOERA, P. G. Problemi e prospective della sterilizzazione con raggi gama di prodotti farmaceutici. Boll.Chim.Farm., Milano, v. 114, n. 4, p. 185-189, 1975.

44 - CASAMAdA, R. S. M. Tratado de Farmacognosia. Madrid: Editorial Ci entifico-Medica, 1977.

45 - CÉSKOSLOVENSKÝ LECOPIS, 2 vyó (1954). Czechoslovakian Pharmacopoeia. 2. ed. Prague, p. XVII. Apud: WORLD HEALTH ORGANIZATION. Microbio logical Contamination of nonsterile drugs. WHO/PHARM/69453. $10 \mathrm{p}$. [Mimeogr:] 
46 - CHILE. Ministério de Salud. Instituto de Salud Publica de Chile. Compendio de aspectos teörico prticos en el manejo de areas de contaminación controlada. Santiago de Chile: Editorial Universita ria, 1984.

47 - COMMITTE OF OFFICIAL LABORATORIES AND DRUG CONTROL SERVICES. Section of Industrial Pharmacists-FIP. Microbiological purity of non-conipulsory sterile pharmaceutical preparations: methods of examination. Pharm.Acta Helv., Zurich, v. 51, n. 3, p. 33-40, 1976.

48 - COOKE, E. M., SHOOTER, R. A., O'FARREL, S. M., MARTIN, D. R. Faecal carriage of Pseudomonas aeruginosa by newborn babies. Lancet., London, v. 2, n. 7682, p. 1045-1046, 1970.

49 - CORTEZ, Y., PERSONNË, J. C., ESTÈVE, G. Étude comparative de la contamination de plantes médicinales. Plantes Mëd.Phytother., Angers, v. 20, n. 3, p. $236-250,1986$.

50 - costa, A. F. Farmacognosia. 2. ed. Lisboa: Calouste Gulbenkian, 1982, v. 3, p. 927.

51 - Costa, A. F. Farmacognosia. 3. ed. Lisboa: Calouste Gulbenkian, 1987, v. 2, p. 748.

52 - DEPARTMENT OF HEALTH EDUCATION AND WELFARE. Bacteriologicòl analytical manual. 5.ed. Washington: Division of Microbiology, Food and Drug Adritinistration, 1978.

53 - oesvignes, n. , SÉbastien, e., bernard, J., CAMPion, G. Étude de la contamination microbienne de diverses préparations pharmaceutiques. Ann.Pharm.Fr., Paris, v. 31, n. 2, p. 775-785, 1983. 
54 - DEVLEESCHOUWER, M. J., DONY, J. Flore microbienne des médicaments. Données écologiques et sensibilité aux antibiotiques - 1 ère partie: Formes magistrales sèches. J.Pharm.Belg., Bruxelles, v. 34 , n.4, p. 189-203, 1979.

55 - OEVLEESCHOUWER, M. J., DONY, J. Normes microbiologiques des dro gues d'origine végétable et leurs mélanges. J.Pharm.Belg., Bruxelles, v. 34, n. 5, p. 260-266, 1979.

56 - DeVleEsChOUWER, M. J., AKIN, A., DONY, 3. Flore microbienne des médicaments. Données écologiques et sensibilité aux antibiotiques. 2e. partie: Forme magistrale liquide. J.Pharm.Belg., Bruxelles, v. 35, ก. 4, . $266-272,1980$.

57 - DICTIONAIRE Encyclopedic Larousse. Paris: Librairie Larousse, 1972.

58 - DiCTIONARY of Scientific and Technical Terms. 2.ed. New York: Mc. Graw-Hill, 1978, p. 491.

59 - DIDING, N., WERGEMAN, L., SAMUELSSON, G. Ethylene oxide treatment Part I. Introduction and bacteriological results. Acta Pharm. Suec., Stockholm, v. 5, n. 3, p. 177-182, 1968.

60 - DoCumento S.I.S.F. Proposta "Gruppo biologico". "Metodi per il controllo microbiologico de farmaci non sterili". PA/PH Exp. 1 $\mathrm{cm} / \mathrm{t}$ (75) 1. 12/2/75. Apud: TAGL IAPIETRA,L. La qualitá microbio logica nei prodotti farmaceutici non obbligatoriamente sterili. Boll.Chim.Farm., Milano, v. 117, n. T, p. 1-13, 1978. 
61 - DONY, J., GÉRARD, P. La contamination microbienne des medicaments et l'établissement de normes de qualité bactériologique. J.Mond.Pharm., La. Haye, v. 11, n. 1, p. 19-32, 1968.

62 - DONY, J. La qualité microbiologique des médicaments matières-premières et produits terminés. Labo-Pharma.Probl.Tech., Paris, v. 25, n. 262 , p. $113-121,1977$.

63 - DUKE, 3. A. Handbook of medicinal herbs. Boca Raton: CRC, 1985.

64 - EIKOFF, T. C. Nosocomial salmonellosis due to carmine. Ann. Intern.Med., Philladelphia, v. 66, n. 4, p. 813-814, 1967.

65 - EL SOVOD, S. M. A. Fungal contarination of certain pharmaceutical powders, Indian J.Pharm.Sci., 47 (Nov-Dec): 197-201, 1985. Apud: Int. Pharm.Abstr., Washington, 24, (Jan-Jun): 2404399, 1987.

66 - ERNERFELDT, F., KALLINGS, L. -0., RINGERTZ, 0., SILVERSTOPE, L. Bacteriological hazards in pharmaceutical manufacturing. Acta Pathol. Microbiol. Scand., Copenhagen, v. 66, n. 2, p. $287,1966$.

67 EVANS, F. T. Infection from spinal analgesia. Lancet, London, v.2, $n$. 7165, p. $115,1945$.

68 - EVANS, J.R., GILDEN, M. M., BRUCH, C. W. Methodsfor isolating and identifying objectionable gram-negative bacteria and endotoxins from topical products. J.Soc.Cosmet.Chem., Easton, v. 23, n. 9, p. $549-564,1972$. 
69 - FARMACOPÉIA brasileira. 3 ed. São Paulo: Organização Andrei, 1977.

70 - FARMACOPÉIA brasileira. 4 ed. São Paulo: Atheneu, 1988.

71 - FARMACOPÉIA dos Estados Unidos do Brasil. 2 ed. Sào Paulo: Siqueira, 1959.

72 - FERREIRA, J. M., FREITAS, Y. M. Microbiological survey of talcum powders and raw materials. Cosmet. Toiletries, Oak Park, v. 91, n. 9, p. $19-26,1976$.

73 - FISCHER, A., SMIDT, B. F., ULRICH, K. Microbial content in non-sterile pharmaceuticals IV. Tablets. Dan.Tidsskr.Farm., Copenhagen, v.42, n. 5, p. $125-131,1968$.

74. FRANCE, D. R. Survival of Candida albicans in hand creams .Nz.Med.J., Wellington, v. $67, n .432$, p. 552-554, 1968.

75 - FRANK, B. Microorganisms in crude drugs: microbiological status of crude drugs and their preparations and its evaluation. Dtsch. Apoth. Ztg., Stuttgart, 129 (Mar30): 617-623, 1989. Apud: Int.Pharm.Abstr., Washington, v. 27, ก. 17, p. 2711368, 1990.

76 - GALLIEN, R. Mikrobielle kontamination von Fertig-produkten und Rohs toffen-Problematik, Ergebnisse, SchluBfolgerungen. Pharm.Ind., Aulendorf, v. 34, ก. 8, p. 929-932, 1972.

77 - GASCHEN, M. Hygiène et fabrication de médicaments, Pharm.Acta Helv., Zurich, v. 49, n. 7/8, p. 261-265, 1974. 
78 - GRAF, V. E., SCHEER, R., SCHÖLLHORN, T. L. Beeinflussung von mikroorganismens durch den tablettrervorgang. Teil 1: Preßverhalten der ein gesetzten granulate und eizielle keim reduktionen. Pharm.Ind., Aulendorf, v. 51, n. 2, p. 193-198, 1989.

79 - GUPTA, K. G., VYAS, K. K., SEKHON, N. S. Effect of radiation on activity of antibiotics. J.Pharm.Sci., Washington, v. 62, n. 5, p. 841$842,1973$.

80 - GYríRGY, K. Ōjabb Mikrobiológiai Szempontok a gyógyszertechnológiăban. Gyōgyszerēszet, Budapest, v. 18, n. 4, p. 121-125, 1974.

81 - HARDY, P. C., EDERER, G. M., MATSEN, J. M. Contamination of commercially packaged urinary catheter kits with the Pseudomonas E0-1. N.Engl. J.Med., Boston, v. 282, n. 1, p. 33-35, 1970.

82 - Ḧ̈RTLING, C. Untersuchungen über den mikrobiellen zustand von Laxatien auf pflanzlicher Basis. Pharm.Ztg., Frankfurt, v. 128, n. 19, p. $1006-1008,1983$.

83 - HEIN, V. H., MIKLOVICH, M. Untersuchungen über den keimgehalt einiger sur Herstellung von Arzneimitteln benutzter. Roh-und Hilfsstoffe. Pharm.Ind., Aulendorf, v. 38, n. 4, p. 407-411, 1976.

84 - HENNING, H. M. Die mikrobiologische Prüfung von "nicht sterilen" pharmazeutischen Präparaten auf keimzahl und keimart. Pharm.Ind., Aulendorf, v. 32, ก. 4a, p. 253-259, 1970.

85 - HIRSCH, J. I., ANDREW, T. C. JR., RANDALL, E. L. Microbial contamination of oral liouid medications. Am.J.Hosp.Pharm., Washington, v. 26, p. $625-629,1969$. 
86 - HITOKOTO, H., MOROZUMI, S., WAUKE, T., SAKAI, S., KURATA, H. Fungal con tamination and mycotoxin detection of powdered herbal drugs. Appl. Environ.Microbiol., Washington, v. 36, n. 2, p. 252-256, 1978.

87 - HOPES, T. M. Quality control of raw materials. Orug.Cosmet. Ind., New York, v. 100, n. 4, p. 46-49 134-138, 1972.

88 - IARIA, S. T., FuRlanetTo, S. M. P., CAMPOS, M. L. C. Técnicas utilizadas em exercicios prăticos. Disciplina de Microbiologia de AlimentosCurso de Pós Graduação do Instituto de Ciências Biomédicas da Universidade de São Paulo, São Paulo, 1981. [apostila]

89 - INFECTION at Birmingham and Midlands Eye Hospital. Br.Med.J., London, v. 2, n. 5473, p. 1316, 1965.

90 - international pharmacopeia. 2 ed., Geneva, World Health Organization, 1967. p. xxxiv.

91 - JAIN, N. K., CHAUHAN, C. S. Microbial contamination in antacid tablets. Indian J.Hosp.Pharm., 15 (5): 137-138, 1978. Apud: Int..Pharm.Abstr., Washington, v. 16, n. 18, p. 164774, 1979.

92 - KAgRamanOVA, K. A., KIVMAN, G. Y. Isolation and identification of microorganismos in nonsterile drugs. Pharm.Chem., New York, v. 15, n. 4, p. 296-300, 1982.

93 - KALLINGS, 0., RINGERTZ, 0., SILVERSTOPE, L., ERNERFELDT, F. Hicrobiological contamination of medical preparations Act.a Pharm.Suec., Stockholm, v. 3, n. 3, p. 219-228, 1966. 
94 - KAUL, B. L. K., BRADU, B. L. Studies on the induced mutations in medicinal plants I. Spectrum of adult plant mutations in Atropa belladonna. Planta Med., Stuttgart, v. 20, n. 3, p. 205-210, 1971.

95 - KEOZIA, B., HOLDERNA, $\varepsilon$. Wystepowanie bakterü tlenowych in grzybów w surowcach zielarskich. Herb.Polon., Páznan, v. 30, n. 1, p. 59-70, 1984.

95 - KOBURGER, J. A., MARTH, E. H. Yeasts and Molds. In: AMERICAN PUBLIC HEALTH ASSOCIATION. Technical Committee on Microbiological Methods for Foods. Compendium of methods for the microbiological examination of foods. 2 ed. Washington, 1984. p. 197-202.

97 - KOMARMY, L. E., OXLEY, M. E., BRECHER, G. Hospital-acquired salmonellosis traced to carmine dye capsules. N.Engl.J.Med., Boston, v. 276, $\mathrm{n}$. 15 , p. $850-852,1967$.

98 - KRAIOMAN, G. The Microbiology of airborne contamination and air sampling. Drug Cosmet. Ind., New York, v. 116, n. 3, p. 40-43, 108-112, 1975.

99 - KRUGER, D. Ein Beitrag zum Thema der mikrobiellen kontamination von Wirk-und Hilfstoffen. Pharm. Ind., Aulendorf, v. 35, n. 9, p. 569-577, 1973.

100 - KUNSCHER, H., NEKOLA, M. Examination of the sterility of pharmaceutical adjuvants. Sci.Pharn., Vienna, v. 38, p. 122-128, 1970.

101 - LAMBin, S., JANOT, M-M., MAURON, D. Éxamen bactēriologique des comprimés pharmaceutiques. Ann.Pharm.Fr., Paris, v. 11, n.8-9, p. 620-637, 1953. 
102 - LANG, D. J., KUNZ, L. J., MARTIN, A. R., SCHROEDER, S. A., THOMSON, L. A. Carmine as a source of nosocomial salmonellosis. N.Engl.J.Med., Boston, v. 276, ก. 15, p. 829-832, 1967.

103 - LAROUSSE Médical. Paris: Larousse, 1974.

104 - LAST, P. M., HARBISON, P. A., MARSH, J. A. Bacteraemia after urologi cal instrumentation. Lancet, London, v. 1, n. 7428, p. 74-76, 1966.

105 - LEITÃO, M. F., ROMEU, A. P., CRUZ, R. R, Coliformes totais e fecais como indicadores de contaminação I - Presença no solo, àgua e vegetais. Colet.I.T.A.L., Campinas, v. 4, p. 1-11, 1971-72.

106 - LEITÃo, M. F., ROMEU, A. P., CRUZ, R. R. Coliformes totais e fecais como indicadores de contaminação Il - Avaliação do teste para caracterização de coliformes fecais. Colet.I.T.A.L., Campinas, v. 4, p. $13-21,1971 / 72$.

107 - LEITÃo, M. F. F. Salmonelas en águas fluviais e en alimentos não processados e industrializados de origem animal e vegetal. São Paulo, 1979. [Tese de doutoramento, Faculdade de Ciências Farmacêuticas USPj

108 - LEITE, C. Q. F., RADDI, M. S. G., MENDONÇA, C. P. Bactérias entéricas nas mãos de manipuladores de alimentos da cidade de Araraquara - S.P. Alim.Nutr., São Paulo, v. 1, p. 23-28, 1989.

109 - LENHINGTON, K. R. Salmonella in drugs and dietary supplements. Drug Cosmet.Ind́., New York, v. 100, n. 3, p. 42-43, 174-175, 1967. 
110 - LENOBLE, M; , FOURNAT, J., BOURLIOUX, P., PARIS, M., MAGHAMI, P., GER MAN, A. Contrôle de la qualité microbiologique d'échantillons de Mentha piperita de diverses origines gejographiques. Ann.Pharm.Fr., Paris, v. 38, n. 4, p. 333-342, 1980.

111 - LINGNAN, V. J. Die Anforderungen bei Wirk-und Hilfstoffen in mikrobiologischen Heinsicht. Pharm. Ind., Aulendorf, v. 32, n. 4a, p. 240$243,1970$.

112 - LUMINI, E. Controllo di qualità nel processo produtivo. Boll.Chim. Farm., Milano, v. 117, n. 1, p. 14-18, 1978.

113 - LUTOM_SKY, V. J., KEDZIA, B. P. Isolierungs und Identifizierungsmethoden von Mikroorganismen. Dtsch.Apoth.Ztg., Stuttgart, v. 119, n. 1, p. $5-9,1979$.

114 - LUTOMSKY, J., KEDZIA, B. Mycoflora of crude drugs. Plantã Med., Sttutgart, v. 40, n. 2, p. 212-217, 1980.

115 - MANUila, A., MaNUILA, L., NICOLE, M;, LAMBERT, H. Dictionaire français de medicine et de biologie. Paris: Masson, 1972.

116 - MEAD, C.A. \& O'NEILL, J. J. A three-day mold assay for cosmetics and toiletries. J.Soc.Cosmet.Chem., v. 37, n. 2, p. 49-57, 1986.

117 - Mehlman, i. J., SANders, A. C., SiMON, N. T., OLSON, J. C. Methodology for recovery and identification of enteropathogenic Escherichia coli. J.Assoc.Off.Anal.Chem., Washington, v. 57, p. 101-110, 1974. 
118 - MEHLMAN, I. J. Coliforms, fecal coliforms, Escherichia coli and enteropathogenic E.COli. In: AMERICAN PUBLIC HEALTH ASSOCIATION. Techni cal Committee on Microbiological Methods for Foods. Compendium of methods for the microbiological examination of foods. 2.ed. Washington, 1984, p. 265-285.

119 - MESMAEKER, E. Aspects légaux de la phytotherapie en Belgique. J.Pharm. Belg., Bruxelles, v. 41, n. 22-29, 1986.

120 - Millet, M., DONY, J., GÉRARd, P. Problèmes posés par la présence de germes dans les medicaments non injectables. J.Pharm.Belg., Bruxelles, v. 20, n. 11-12, p. 467-474, 1965.

121 - MITCHELL, R. G., HAYWARD, A. C. Postoperative urinary-tract infections caused by contaminated irrigating fluid. Lancet, London, v. $1, n$. 7441 , p. 793-795, 1966.

122 - MOLIN, 0. in Contamination in the Manufacture of Pharmaceutical Pro ducts, Geneva, Secretariat of the European Free Trade Association, 1973. p. 33-41. Apud: Flaum, I., Contamination in Pharmaceutical Pro ducts, J.Pharm.Sci., Washington, v. 67, n. 1, p. 1-11, 1978.

123 - MORENO, B. G., DIEZ, V., GARCIA, M. L., POLLEDO, J. J.F. Microorganismos de los alimentos 1. Técnicas de anälisis microbiologico. Zaragoza: Acribia, 1983.

124 - MORSE, L. J., WILLIAMS, H. L., GRENN, F. P. J., ELDRIDGE, E. E., ROTTA, J. R. Septicemia due to Klebsiella pneumoniae originating from handcream dispenser. N.Engl.J.Med., Boston, v. 277, n. 9, p. 472-473, 1967. 
125 - MOSSEL, D. A. A., GARCIA, B. M. Microbiologia de los alimentos: fun damentos ecológicos para garantizar y comprobar la inocuidad y la calidad de los alimentos. Zaragoza: Acribia, 1985.

126 - MOURA, R. A. A., MAMIZUCA, E. M., BORGES, M. F. Microbiologia clínica, São Paulo: Mc Will, 1979.

127 - NANDAPURKAR, S. N., SHANKHPAL, K. V., DEOGRADE, N. G. Bacteria isola ted from the pharmaceutical preparation. Part. I Tablets. Indian J. Hosp.Pharm., 23(Mai-Jun): 131-139, 1985. Apud: Int.Pharm.Abstr., Was hington, v. 23, n. 17, p. 2306834, 1986.

128 - THE NATIONAL Formulary. 12.ed. Washington: American Pharmaceutical Association, 1965.

129 - THE NATIONAL Formulary. 13.ed. Washington: American Pharmaceutical Association, 1970.

130 - NATIONAL HEALTH SERVICE LABORATORIES. Microbial content in non-sterile pharmaceuticals I. Introduction. Dansk.Tidsskr.Farm., Copenhagen, v. 42, ก. 1, Р. 1-4, 1967.

131 - NEGRETTI, F. Ricerche sulla contaminazione microbica dei prodotti fí toterapici. Boll.Chim.rarm., Milano, v. 122, n. 9, p. 441-451, 1983.

132 - NOBLE, W. C., SAVIN, J. A. Steroid cream contaminated with Pseudomonas aeruginosa. Lancet, London, v. 1, n. 7433, p. 347-349, 1966.

133 - NOTE Technique Pro Pharmacopéa no 189 - Contrōle de la contamination microbienne dans les produits non obfigatoirement stériles. Bull. Ordre Natl.Pharm., Paris, n. 266, p. 591-600, 1983. 
134 - NOTE Technique Pro Pharmacopoea n 190 - Contrōle de la contamination microbienne dans les plantes médicinales, Bull.Ordre Natl. Pharm., Paris, n. 266, p. 601, 1983.

135 - nOUVeau Larousse Médical Illustré, Paris: Librairie Larousse, 1952. p. 867.

136 - NYSTEN, P. H. Dictionaire de medicine, 6.ed. Bruxelles: H. Dumont, 1834 , p. 213.

137 - OBLINGER, J. L. \& KOBURGER, J. A. The Most Probable Number Technique. In: AMERICAN PUBLIC HEALTH ASSOCIATION. Technical Committee on Micro biological Methods for Foods. Compendium of methods for the microbiological examination of foods. 2.ed. Washington, 1984, p. 99-111.

138 - OHARA, M. T. Contaminação microbiana em medicamentos não estéreis soluções para uso oral. São Paulo. 1984. 70 p. [Dissertação-Miestrado, Faculdade de cièncias Farmacéuticas - USP].

139 - OHARA, M. T., SAITO, T. Medicamentos não estëreis 1 - Contarinação microbiana em soluções para uso oral. Rev.Farm.Bioquīm.Univ.S.Paulo, São Paulo, v. 20, n. 1, p. 17-27, 1984.

140 - OHARA, M. T., SAITO, T. Medicamentos não estéreis III - Contaminação microbiana em suspensão para uso oral. Rev.Farm.Bioquím.Univ.S.Pau10, São Paulo, v. 21, n. 1, p. 71-79, 1985.

141 - OLIN, G., LITHANDER, A. Toxin-forming Staphylococci, as a cause of deaths on the injection of infected bacteriological preparations. Acta Pathol.Microbiol.Scand., Copenhagen, v. 25, n. 1-2, p. 152-160, 1948. 
I42 - OLIVEIRA, F., AKISUE, G. Fundamentos da Farmacobotānica. Rio de Janeiro: Atheneu, 1989.

143 - Oliveira, F., AKISUE, G., AKISUE, M. K. Farmacognosia. São Paulo: Atheneu, 1991.

144 - PARIS, R. R., MOYSE, H. Précis de Matiēre Medicale. 2.ed., Paris: Masson, 1976.

145 - PARKER, M. T. The clinical significance of presence of microorganisms in pharmaceutical and cosmetic preparations. 3.Soc.Cosmet.Chem., New York, v. 23, n. 7, o. 415-426, 1972.

146 - PEDERSEN, E. A. \& SZABO, L. Microbial content in non-sterile pharmaceu ticals II. Methods. Dan.Tidsskr.Farm., Copenhagen, v. 42, n. 2, p. 50-55, 1968.

147 - PEDERSEN, A. E., ULRICH, K. Microbial content in non-sterile pharma ceuticals. Dansk.Tidsskr.Farm., Copenhagen, v. 42, n. 3, 3. 71-83, 1968.

148 - PENSO, G. Problemi relative all'uso delle piante medicinali nel mondo. Boll.Chim.Farm., Milano, v. 116, n. 9, p. 506-519, 1977.

149 - PENSO, G. Mërioire présenté aux J. P. F., 1969. Apud: DESVIGNES, f., SÉBASTIEN, F., BERNARD, J., CAMPPION, G. Étude de la contamination microbienne de diverses préparations pharmaceutiques. Ann.Pharm.Fr., Paris, v. 31, n. 2, p. 775-785, 1983. 
150 - PEPPLER, H. U., GUARINO, P. A. Spices and gums. In: AMERICAN PUBLIC HEALTH ASSOCIATION. Technical Committee on Microbiological Methods for Foods. Compendium of methods for the microbiological examination of foods. 2.ed. Washington, 1984, p. 651-662.

151 - PERSONNÉ, J. C., ESTÉVE, G., LOZANO, F. La propreté microbiologique des préparations pharmaceutiques et cosmetiques: position du Labora torie National de la Santé. Labo-Pharma Probl.Tech., Paris, v. 25, n. 270, p. $885-890,1977$.

152 - PHARMACopeia dos Estados Unidos do Brasil. São Paulo: Macional, 1926.

153 - PhaRmacopoea Helvetica. 6.ed. Berne: Office Central Féderal des imprimés et du matériel, 1971.

154 - PHILLIPS, I. Postoperative respiratory-tract infection with Pseudomo-

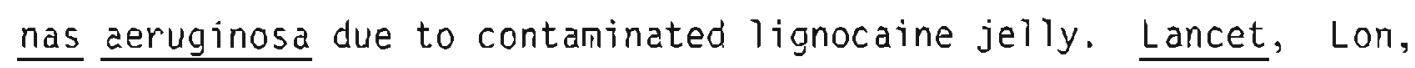
don, v. 1, n. 7443, p. 903-904, 1966.

155 - PHILLIPS, I., EYKYN, S., CURTIS, H. A., SNELL, J. J. S. Pseudomonas cepacia (multivorans) septicaemia in an intensive-care unit. Lancet, London, v. 1, n. 7695, p. 375-377, 1971.

150 - PINTO, P. A. Dicionário de termos médicos. 8.ed. Rio de Janeiro: Ed. Cientifica, 1962. p.153.

157 -PLOTKIN, S. A., MCKITRICK, J. C. Nosocomial meningitis of the newborn caused by a Flavobacterium. J.Am.Med.Assoc., Chicago, v. 198, n. 6, p. $662-664,1966$. 
158 - PLUHAPTON, E. J., GILBERT, P., FELL, J. T. Effect of spatial distribution of contaminant microorganisms within tablet formulations on subsequent inactivation through compaction. Int.J.Pharm., Amsteram, v. 30, n. 2-3, p. $237-240,1986$.

159 - PLUMPTON, E. J., GILBERT, P., FELL, J. T. The survival of microorga nisms during tableting. Int.J.Pharm., Amsterdam, v. 30, n. 2-3, p. $241-246,1986$.

160 -POELMA, P. L., ANDREWS, W. H., SILLIKER, J. H. Saimonelia. In: AMERICAN PUBLIC HEALTH ASSOCIATION. Technical Committee on Microbiologi cal Methods for Foods. Compendium of methods for the microbiological examination of foods. 2.ed. Washington, 1984. p. 286-326.

161 - PRESERVATION and quality control of natural materials: a roundtable discussion. Cosmet.Toiletries, Oak Park, v. 102, n. ó, p. 75-84, 1987.

162 - PREVENTION of microbial contamination of medicines. Pharm.J., London, v. 210, n. 5709, p. 270-272, 1973.

163 - PRISTA, L. M., ALVES, A. C., MORGADO, R. Técnica Farmacéutica e Farmäcia Galênica. 3.ed. Lisboa: Calouste Gulbenkian. v.1. 1983. p. 819.

164 - Public Kealth Laboratory Service (Working party) Microbial contamination of medicines administered to hospital patients. Pharm.J., Lon don, v. 207, n. 5622, p. 96-99, 1971. 
165 - PURETÉ microbiologique des formes pharmaceutioues non obbligatoirement stēriles: ler rapport commun du Comité des Laboratoires et Services officiels de Contröle des Medicaments et de la Section des Pharmaciens de l'Industrie - FIP. J.Mond.Pharm., 15: 88, 1972. Apud: DONY, J. La qualité microbiologique des médicaments, matièrespremières et produits terminés. Labo-Pharma.Probl. Tech., Paris, v. 25, n. 262, p. 113-121, 1977.

166 - QUEVEDO, F. Contaminación microbiana en los productos de aplicación humana (Medicinales y Cosmeticos). Buenos Aires: Organización Pana mericana de la Salud, 1972. p. 577 e 591.

167 - RAY, B., (JR) ADAMS, D. M. Repair and detection of injured microor ganisms. In: AMERICAN PUBLIC HEALTH ASSOCIATION. Technical Committee on Microbiological Methods for Foods. Compendium of methods for the microbiological examination of foods. 2.ed. Washington, 1984. p. $112-123$.

168 - RELAZIONE presentata al Consiglio Naz. di Sanità Svedese, 1965. Documento S.I.S.F. 3. Apud: BONOKI, E., NEGRETTI, F. Ricerche sul contenuto microbico di materie prime impiegate nelle preparazioni farmaceutiche. Ann. Ist. Super Sanità, Roma, v. 13, n. 4, p. 805-832, 1977.

169 - RINGERTZ, 0., RINGERTZ, 5. The clinical significance of microbial contamination in pharmaceutical and allied products. Adv.Pharm.Sci., London, v. 5, p. 211-226, 1982.

170 - ROMOND, C. Aspect technologique des contröles microbiologiques des médicaments, des aliments et des cosmétiques. Labo-Pharm.Probl.Tech., Paris, v. 25, n. 267, p. 543-547, 1977. 
171 - ROY, A. K., CHOURASIA, H. K. Aflatoxin problems in some medicinal plants under storage. Int.J.Crude Drug Res., Lisse, v. 27, n. 3, p. $156-160,1989$.

172 - SAPUELSSON, G., YMAN, B. M. Ethylene oxide treatment of crude drugs. Part. II. Influence on drugs containing glycosides. Acta Pharm.Suec., Stockholm, v. 5, п. 3, p. 183-198, 1968.

173 - SAMUELSSON, G., YMAN, 8. M. Ethylene oxide treatment of crude drugs containing alkaloids. Acta Pharm.Suec., Stockholm, v. $5, n .3, p$. $199-204,1968$.

174 - SANDERS, C. V. JR., LUBY, J. P., JOHANSON, W. G., BARNETT, J. A., SANFORD, J. P. Serratia marcescens infections from inhalation therapy. Medications: Nosocomial outbreak. Ann.Intern.Med., Philladelphia, v. 73, n. 1, p. 15-21, 1970.

175 - SANTOS, P. R. V., OE OLIVEIRA, A. C. X., THOMASSINI, T. C. B. Contro le microbiolōgico em fitoterápicos. In: SIMPÓSIO DE PLANTAS MEOICI NAIS DO BRASIL 2, SIMPÓSIO NACIONRL DE FARMACOLOGIA E QUİîiCA DE PROOUTOS NATURAIS, 3, SINPRONAT, 3, João PESSOd, 1990. Livro de resumos. Paraíba, Universidade Federal da Paraíba, 1990 (resumo 7.05).

170 - SAVIN, J. A. The microbiology of topical preparations in pharmaceutical practice. 1. Clinical aspects. Pharm.u., London, v. 199, n. 5420, p. $285-288,1967$.

177 - SCHILLER, I., KUNTSCHER, H., WOLFF, A., NEKOLA, M. Microbial content of nonsterile therapeutic agents containing natural or seminatural active ingredients. Appl.Microbiol., Baltimore, v. 16, n. 12, p. $1924-1928,1968$. 
178 - SCHLATTER, V. B. L., SOLIVA, M., SPEISER, P. Die antimikrobielle behandzeing von peroralen enzynpräparaten mit gama-strahlen. Pharm. Acta Helv., Zurich, v. 49, n. 2, p. 66-75, 1974.

179 - SCHNELER, G. H. Microbial testing of oral dosage forms. Drug.Cosmet. Ind., New York, v. 122, n. 2, p. 48-52, 54-58, 146-152, 1978.

180 - SEVITT, S. Source of two hospital-infected cases of tetanus. Lancet, London, v. 2, n. 6589, o. 1075-1078, 1949.

181 - SHOOTER, R. A., COOKE, E. M., GAYA, H., KUMAR, P., PATEL, N., PARKER, M. T., THOM, B. T., FRANCE, D. R. Food and medicaments as possible sources of hospital strains of Pseudomonas aeruginosa. Lancer, London, v. 1 , ก. 7608, p. 1227-1229, 1969.

182 - SINOTTE, P.L. Tabletting controls. Drug Cosmet.InE., New York, $v$. 105, n. 3, p. 47-50, 166-171, 1969.

183 - SMART, R., SPOONER, D. F. Hicrobiological spoilage in pharmaceuticals and cosmetics. J.Soc.Cosmet.Chem., London, v. 23, n. 11, p. 721-737, 1972.

184 - SMIDT, B. F., ULRICH, K. Microbial content in non-sterile pharmaceuticals V. Tablets. Dan.Tidsskr.Farn., Copenhagen, v. 42, n. Q, p. $257-263,1968$.

185 - SPEISER, P. Wissenschaftliche Anforderungen an sterile Präparate. Pharm.Acta Heiv., Zurich, v. 48, n. 2, p. 63-82, 1973.

186 - SPELLER, D. C. E., STEPHENS, ?. E., VIANT, A. C. Hospitä infection by Pseudomonas cepacia. Lancet, London, v. 1, n. 7703, p. 798-799, 1971 . 
187 - SPILTTSTOESSER, D. F., MUNDT, J. 0. Fruits and vegetables. in: AHERICAN PUBLIC HEALTH ASSOCIATION. Technical Committee on Hicrobiological Methods for Foods - Compendium of methods for the microbiological exarination of foods. 2.ed. Washington, 1984, 0. 636-650.

188 - SWEDISH NATIONAL BOARD OF HEALTH Production, hygiene and bacteriological control in the manufacture of pharmaceuticals. Document $n^{0} \quad 175$, Stockhoim, 1967. Apud: TAGLIAPIETRA, L. La qualità microbiologica nei prodotti farmaceutici non obbligatoriamente sterili. Boll.Chin. Farm., Milano, v. 117, n. 1, p. 1-13, 1978.

189 - SWEDISH NATIONAL BOARD OF HEALTH. "Production, hygiene and bacteriological control in the manufacture of pharmaceuticals". Document $n=115$, Stockholm, 1967. Apud: TAGLIAPIETRA, L. La qualità microbiologica nei prodotti farmaceutici non obbligatorianente sterili. Boll.Chim. Farm., liilano, v. 117, n. 1, p. 1-13, 1979.

190 - SYKES, G. The control of microbial contamination in pharmaceutical products for oral and topical use. Raw materials. J.Mond.Pharm., La Haye, (1-2): 14-21, 1971. Apud: BONOAI, E., NEGRETTI, F. R cerche sul conteuto microbico di materie prime impiegatte nelle preparazioni farmaceutiche. Ann. Ist. Super. Sanità, Rona, v. 13, n. 4, p. 805$832,1977$.

191 - TAGL IAPietra, L. La qualità microbiologica nei prodotti farmaceutici non obbligatoriamente sterile. Boll.Chim.farm., Milano, v. 117, n. 1, p. $1-13,1978$.

192 - TERAN, E. A espirulina - un novo modismo brasileiro. Rev.Bras.farmacog., São Paulo, v. 2, 3 e 4, p. 197-207, 1987-1989. 
193 - ThOMAS, C. C., HOCKING, G. H. A dictionary of terms in pharmacognosy and economic botany. Springfield, 1955, p. 63.

194 - THOMPSON P. J., STEVENSON, K. E. Mesophilic aerobic sporeformers. In: AMERICAN PUBLIC HEALTH ASSOCIATION. Technical Committee on Micro biological Methods of Foods. Compendium of methods for the microbiological examination of foods. 2.ed. Washington, 1984.

195 - THE UNITED States Pharmacopoeia. 8.ed. Philadelphia: Lippincott, 1905.

196 - THE UNITED States Pharmacopoeia. 10.ed. Philadelphia: Lippincott, 1920.

197 - THE UNITED States Pharmacopeia. 11.ed. Easton: Nack, 1936.

198 - THE UNITED States Pharmacopeia. 12.ed. Easton: Mack, 1942.

199 - THE UNITED States Pharmacopeia.. 13.ed. Easton: Mack, 1947.

200 - THE UNITED States Pharmacopeia. 14.ed. Easton: Mack, 1950.

201 - THE UNITED States Pharmacopeia. 15.ed. Easton: Mack, 1955.

202 - THE UNITEd States Pharmacopeia: 16.ed. Easton: Mack, 1960.

203 - THE UNited States Pharmaccpeia. 17.ed. Easton: Mack, 1965.

204 - THE UNITED States Pharnacopeia. 18.ed. Easton: Mack, 1970.

205 - THE UNITED States Pharmacopeia. 19.ed. Rockville: The United States Pharmacopeial Convention, 1975. 
206 - THE UlHIted States Pharmacopeia. 20.ed. Rockville: The United States Pharmacopeial Convention, 1980.

207 - THE UNITED States Pharmacopeia. 21.ed. Rockville: The United States Pharmacopeiàl Convention, 1985.

208 - THE UNITED States Phamacopeia. 22.ed. Rockville: The United States Pharmacopeial Convention, 1990.

209 - U. S. DEPARTMENT of Health, Education and Welfare. Follow-up on septicemias associated with contaminated Abbott intravenous fluids. Horbidity Hortality Weekly Rep., Atlanta, v. 20, n. 11, p. 91-\$2, 1971.

210 - WALLHAUBER, K. H. Die microbielle reinheit von "nicht sterilen" arz neimitteln. Pharm.Ind., Aulendorf, v. 34, n. 8, p. 549-551, 1972.

211 - WATERHAN, R. F., SUMNER, E. J., BALDWIN, J. N., WARREN, F. W. SUrvi val of Staphylococus aureus on pharraceutical oral solid dosage forms. J.Pharm.Sci., Washington, v. 62, n. 8, p. 1317-1320, 1973.

212 - WELCH, H., SLOCUH, G. G., HERWICK, R. P. Teranus from sulfonamid dusting powders. JAMA J.Am.Med.ASSOC., Chicago, v. 120, n.5, p. $361-364,1942$.

213 - WESTWOOD, N. Microbial contanination of some pharmaceucical raw materials. Pharri.J., London, v. 207, n. 5622, p. 99-103, 1971.

214 - WHO/PHARM 74477. ADUd: COMHAITTEE OF OFFICIAL LABORATORIES AND DRUG CONTROL SERVICES Section of Industrial Pharmacists FI? - Microbio logical purity of non-compuisory sterile pharmaceutical preparations: methods of examination. Pharm.Acta Helv., Zurich, v. 51, n. 3, p. $33-40,1976$. 
215 - WIDMANN, A., CROOME, R. U. Gelatine-Mikrobiologischer Status. Pharm. Ind., Aulendorf, v. 37, n. \&, p. 650-65\&, 1975.

210 - WÖZNIAK, W., SZEPIETOWSKA, B., ZAGÖRSKI, Z. P. Investigation of sterility of selected pharmaceutical raw materials. Acta Pol.Pharm., Varsövia, v. 29, ก. 6, p. 638-648, 1972.

217 - WYK, R. W. V., GRANSTON, A. E. A bacteriological study of ophtalmic ointments. J.An.Pharm.Assoc. Sci Ed., v. 47, n. 3, p. 193-196, 1958.

218 - yANAGITA, T., MIKI, T., SAKAI, T., HORIKOSHI, I. Microbiological stu dies on drugs and their raw-materials. I. Experiments on the reduction of microbial contaminants in tablet during processing. Chem.Pharm. Bu11., Tokyo, v. 25, n. 1, p. 185-190, 1978.

219 - yokOYA, F. Controle de Qualidade, Higiene e Sanitização nas rábricas de Alimentos. São Paulo: Fundação Técnica de Pesquisas e Técnologia, 1982. 